\title{
Register of New Fruit and Nut Cultivars List 47
}

\author{
Ksenija Gasic, Co-editor \\ School of Agricultural, Forest, and Environmental Sciences \\ Clemson University \\ 105 Collings Street \\ Clemson, SC 29634 \\ John E. Preece, Co-editor \\ National Clonal Germplasm Repository \\ USDA-ARS \\ One Shields Avenue \\ University of California \\ Davis, CA 95616-8607
}

Crop Listings ${ }^{\mathrm{z}}$. Almond, Almond Rootstock, Apple, Apricot and Pubescent-Skinned Prunophora Hybrids, Apricot Rootstock,

Blackberry, Blue Honeysuckle, Blueberry, Citrus, Citrus Rootstock, Cranberry, Currant, Elderberry, Ligonberry, Grape, Nectarine, Peach, Peach Rootstock, Persian Walnut, Plum, Plum Rootstock, Pomegranate, Raspberry, Strawberry

\section{ALMOND}

\section{Thomas Gradziel, Plant Science, University of California, Davis,} CA

Independence. High quality, self-compatible and self fruitful almond. Origin: Modesto, CA by Zaiger Genetics. Introduced in 2010. USPP 20,295; 15 Sept. 2009. All-in-One $\times$ almond seedling 21G8. Lineage includes Jordanolo (almond $\times$ peach). Nut: highquality, medium thick; color is light. Kernel: $65 \%$ of nut with moderately sealed paper shell. Harvests with Nonpareil. Tree: upright to moderately spreading and vigorous, being somewhat smaller than Nonpareil; blooms with Nonpareil. Chilling Requirement: approximately $400 \mathrm{~h}$ below $45^{\circ} \mathrm{F}\left(7^{\circ} \mathrm{C}\right)$. Self-compatible and self-fruitful; cross-compatible with Nonpareil and all commercial cultivars.

Supareil. High quality almond similar to Nonpareil. Origin: Chico, CA by B. Crocker. Introduced in 2011 by Burchell Nursery; USPP 21,934; 31 May 2011. Originated in the late 1990s as a chance seedling of unknown parentage within a commercial Nonpareil orchard. Nut: high-quality; similar to Nonpareil though approx. $10 \%$ smaller. Kernel: $65 \%$ of nut with well-sealed paper shell. Harvest 10 to 14 days after Nonpareil. Tree: upright and vigorous, bears primarily on spurs; blooms with to just before Nonpareil; cross-compatible with Nonpareil, Carmel, Aldrich, Fritz, Price and Wood Colony.

Sweetheart. High quality, high oleic acid content almond. Origin: Davis, CA by T.M. Gradziel, Agr. Expt. Sta., Univ. of California. Introduced in 2009. USPP 19,436; 11 Nov. 2008. SB3, 54-39E × 25-26.

Very special thanks to David Karp, Associate in the Agricultural Experiment Station, University of California, Riverside, for his work in enlisting contributors for tropical fruits and compiling, editing, and researching submissions for this crop area for List 47.

${ }^{{ }^{2}}$ Special thanks to the crop contributors for compiling this information. Individuals with cultivars to describe should contact the crop editors directly. DISCLAIMER OF LIABILITY AND ACCURACY: This information is provided as a courtesy of the American Society for Horticultural Science (ASHS) and is presented with the explicit understanding that ASHS and its authors are not rendering any professional service or advice. While ASHS does its best to present current, accurate, and complete information, the information provided herein may be changed at any time by its owners, or become outdated. Readers are encouraged to inquire further for confirmation of all information on cultivar description and intellectual property protection. ASHS strictly disclaims the accuracy or completeness of the information contained herein. ASHS and its authors strictly disclaim any liability whatsoever, direct or indirect, for any damages of any kind resulting from the use of this material.
Lineage includes Mission, Harriott, Eureka and Nonpareil $\times$ Lukens Honey peach. Nut: kernel is very high-quality with an oleic acid content of approx. 70\%. Cordate-shape resembles Marcona though approx. $10 \%$ smaller; $68 \%$ kernel to nut; very few doubles. Shell: soft and well-sealed; matures 10 to 14 days later than Nonpareil. Tree: upright and open, bears primarily on spurs; blooms with to just before Nonpareil; cross-compatible with Nonpareil and all commercial cultivars except Winters.

\section{ALMOND ROOTSTOCK}

Thomas G. Beckman, USDA-ARS Southeastern Fruit and Tree Nut Res. Lab. Byron, GA

Densipac. Compatible with some almond cultivars. Described under Peach Rootstock.

HBOK 27. Compatible with almond cultivars. Described under Peach Rootstock.

\section{APPLE}

James J. Luby and David S. Bedford, Dept. of Horticultural Science, University of Minnesota, St. Paul, MN

Artemisz. Medium-large red fruit, harvested midseason, multiple disease resistance, and suitable for fresh consumption or apple chip products. Origin: Corvinus University of Budapest, Budapest, Hungary by M. Tóth,G. Ficzek, I. Király, S. Koavács, M. Hevesi, J. Halász, and Z. Szani. Prima O.P.; selected as MR-03 in 1992. DNA markers support Jonathan as the pollen parent. HortScience 47:17951800. Fruit: conic, $55 \mathrm{~mm}$ height x $72 \mathrm{~mm}$ diameter, moderate ribbing, nearly $100 \%$ brown-red blush and inconspicuous stripes, flesh is very firm, crisp, moderately juicy, tart-sweet baland and highly aromatic, may exhibit sunburn or bitter pit. Tree: medium vigor, with strong central leader and spreading habit; bears fruit on both spurs and long shoots; precocious; annual bearing and productive; resistance (Vf/Rvi6) to apple scab (Venturia inaequalis Cke), powdery mildew [Podosphaera leucotricha, Ell. and Ev. (E.S.Salmon)] and fire blight shoot infection [Erwinia amylovora Burr. (Winsl. et al.)].

B3F44. Late season, bicolor fruit with long storage and shelf life. Origin: Better3Fruit, N.V., Rillaar, Belgium by I. De Wit, H. Eyssen, J. Keulemans, J. Nicolai, E. Pauwels and P. Van Laer. Braeburn $\times$ Gala; USPP 23,823; 27 Aug 2013. Fruit: conic with moderate crowning at calyx end, $50 \%$ to $75 \%$ red blush with weak to strong 
stripes in overcolor on yellow-green ground color, moderate to high soluble solids content $\left(13.9^{\circ}\right.$ Brix $)$ and high acidity $\left(7.9 \mathrm{~g} \cdot \mathrm{L}^{-1}\right.$ malic acid) at harvest; very firm, crisp and juicy with strong aroma; low sensitivity to bruising; storage for at least 10 months in ambient atmosphere and 12 months in controlled atmosphere and 4-week shelf life. Tree: medium vigor with ramified, drooping habit, annual bearing on long shoots and spurs with medium precocity and productivity.

B3F45. Late season, bicolor fruit with very firm flesh, long storage and long shelf life, very sweet taste. Origin: Better3Fruit, N.V., Rillaar, Belgium by I. De Wit, H. Eyssen, J. Keulemans, J. Nicolai, E. Pauwels and P. Van Laer. Gala $\times$ Braeburn; USPP 23,847; 13 Aug. 2013. Fruit: globose with moderate crowning at calyx end, $77 \mathrm{~mm}$ diameter $\times 70 \mathrm{~mm}$ height, $50 \%$ to $75 \%$ red blush with weak to strong stripes in overcolor on yellow-green ground color; high soluble solids content $\left(16.2^{\circ}\right.$ Brix $)$ and high acidity $\left(8.3 \mathrm{~g} \cdot \mathrm{L}^{-1}\right.$ malic acid $)$ at harvest; very firm, crisp and juicy with medium aroma; low sensitivity to bruising; storage for at least 9 months in ambient atmosphere and 12 months in controlled atmosphere and 3-week shelf life. Tree: strong vigor with ramified, upright-spreading habit, annual bearing on long shoots and spurs with medium precocity and productivity, medium susceptibility to scab.

CH 101. Fruit similar to Gala but having higher sugar content and scab resistance. Origin: Wadenswil, Switzerland at Agroscope Changins-Wadenswil by M. Kellerhals. Gala $\times$ K1R20A44; USPP 23,236; 4 Dec. 2012. Fruit: globose with moderate ribbing and crowning at calyx end, $78 \mathrm{~mm}$ diameter, orange-red blush, stripe and mottled overcolor over light yellow ground color, flesh is firm, fine texture, very sweet $\left(15^{\circ}\right.$ Brix $)$, and very juicy. Tree: low to medium vigor, spreading habit, bearing on spurs and long shoots, resistant to scab (Vf/Rvi6) and susceptible to Nectria canker (Nectria galligena Bres.) and powdery mildew.

CN B60. Fruit similar to Honeycrisp in texture but larger, flatter in shape, later maturing, firmer, more acid, and less prone to bitter pit. Origin: Worthington, MN by C. Nystrom. Honeycrisp O.P. planted in 1994 and selected in 2004; USPP 23,862; 3 Sept. 2013. Fruit: flatround, moderately asymmetrical, lightly ribbed, $77 \mathrm{~mm}$ height $\mathrm{x}$ $95 \mathrm{~mm}$ diameter, mostly red blush overcolor with some blotchy striping, yellow ground color; flesh is firm, crisp, juicy with high soluble solids ( $14.3^{\circ}$ Brix) and acidity; storage for at least six months in ambient atmosphere and refrigeration. Tree: low to medium vigor, upright, spreading with moderately heavy spur development, precocious and highly productive.

CN 121. Fruit similar to Honeycrisp but with more overcolor, firmer flesh with higher soluble solids and lower acidity. Origin: Worthington, MN by C. Nystrom. Honeycrisp O.P.; USPP 23,777; 30 July 2013. Fruit: conical to sometimes round, often asymmetrical, $75 \mathrm{~mm}$ height $\times 84 \mathrm{~mm}$ diameter, striped red overcolor and yellowgreen ground color; flesh is firm, crisp, melting, juicy, sweet and subacid; storage up to 5 months in ambient atmosphere refrigeration. Tree: medium vigor, upright to upright-spreading habit, moderate productivity.

Cordelia. Late season ripening with bicolor, large, very firm fruit, multiple disease resistance, and suitable for long-term storage. Origin: Corvinus University of Budapest, Budapest, Hungary by M. Tóth, G. Ficzek, I. Király, S. Kovács, M. Hevesi, J. Halász, and Z. Szani. Prima $\times$ Granny Smith, selected as MR-12 in 1993. HortScience 47:1795-1800. Fruit: ellipsoid, $78 \mathrm{~mm}$ height $\mathrm{x}$ $84 \mathrm{~mm}$ diameter, moderate ribbing, 40 to $60 \%$ red blush and stripes over yellow-green ground color; flesh is white, very firm, crisp, juicy, subacid and perfumed. Tree: medium to high vigor, with strong central leader and spreading habit, bears fruit mainly on spurs; precocious and productive; resistance ( $/ f /$ Rvi $)$ to apple scab, powdery mildew and fireblight (shoot and flower infection).
DS 22. Similar fruit to Honeycrisp but ripening 5 days earlier. Origin: Holman, WI by D. Shefelbine. Honeycrisp O.P.; USPP 23,933; 1 Oct. 2013. Fruit: large, short, oblate, symmetrical, $76 \mathrm{~mm}$ height x $90 \mathrm{~mm}$ diameter, $80 \%$ to $90 \%$ blotchy, striped red overcolor and yellow-green undercolor; moderately firm, crisp, juicy flesh with mild aroma and moderate acidity and soluble solids content (13.1 ${ }^{\circ}$ Brix) and slow browning. Tree: medium vigor, spreading habit, moderately heavy spur development, precocious.

DS 3. Fruit similar to Honeycrisp but larger, more stripy and less blotchy skin, higher acidity and 10 days later ripening. Origin: Holman, WI by D. Shefelbine. Honeycrisp O.P.; USPP 23,649; 4 June 2013. Fruit: round-conical, $77 \mathrm{~mm}$ height x $89 \mathrm{~mm}$ diameter, $80 \%$ to $100 \%$ red stripe over gray-yellow ground color; flesh is moderately firm, crisp, melting and juicy, similar soluble solids and greater acidity than Honeycrisp. Tree: moderate vigor, upright to upright-spreading habit, moderately heavy spur development, precocious, moderate productivity.

Fujion. Similar to Fuji but sweeter and with more concentrated ripening and scab resistance. Origin: Consorzio Italiano Vivaisti, San Giuseppe di Comacchio, Ferrara, Italy by M. Leis, A. Martinelli, F. Tagliani, D. Azzolini, P. Castagnoli, and A. Castagnoli. U7L-7 $\times$ H-2; USPP 24,092; 17 Dec. 2013. Fruit: obloid, $71 \mathrm{~mm}$ height $x$ $87 \mathrm{~mm}$ diameter, purple-red overcolor of weak blush and well defined stripes over yellow-green ground color; flesh is crisp, juicy, high soluble solids content (14-16 ${ }^{\circ}$ Brix), intensely aromatic; 2 -week shelf life. Tree: medium vigor with spreading habit, bearing on long shoots and spurs on 2-3 year old shoots; precocious and highly productive.

Gemini. Similar to Gala but larger fruit with higher amount blush overcolor and resistance to scab. Origin: Consorzio Italiano Vivaisti, San Giuseppe di Comacchio, Ferrara, Italy by M. Leis, A. Martinelli, F. Tagliani, D. Azzolini, P. Castagnoli, and A. Castagnoli. Gala $\times$ A3-7; USPP 24,091; 17 Dec. 2013. Fruit: conic, $71 \mathrm{~mm}$ height $x$ $82 \mathrm{~mm}$ diameter, smooth skin with little bloom, ruby red blush over yellow-green ground color; firm, crisp, juicy, flesh with slightly acidic taste. Tree: medium vigor with spreading habit, bearing on long shoots and spurs on 2-3 year old shoots; precocious and highly productive, resistant to apple scab and powdery mildew.

Golden Parsi. Sport of Golden Clone B (clone of Golden Delicious) with less russet and an attractive red blush that remains after storage. Origin: South Tyrol, Italy by E. Schmider and T. Braun. USPP 22,$859 ; 17$ July 2012 . Fruit: conic with moderate ribbing, medium to large $(240 \mathrm{~g}), 80-85 \mathrm{~mm}$ diameter x $80 \mathrm{~mm}$ height, solid flush red overcolor with weakly defined stripes on yellow ground color; thin skin with juicy, firm, sweet (15.4 ${ }^{\circ}$ Brix), ripens at the same time as Golden Delicious. Tree: medium vigor, ramified and spreading; sensitive to scab, moderately resistant to fire blight.

Gradirose. Early season, pink-red skin color. Origin: Herault, France by A. Grard and O. Grard. Christmas Rose O.P.; USPP 22,975; 21 Aug. 2012. Fruit: ellipsoid with no ribbing, 75-90 mm diameter $x$ 90 to $100 \mathrm{~mm}$ height, $50 \%$ to $80 \%$ pink-red blush and weak stripe overcolor on yellow-green ground color; thick skin with juicy, firm, strongly aromatic flesh. Tree: high vigor with semi-upright habit and annual bearing on spurs and long shoots.

Gradiyel. Yellow, blushed fruit with more blush, longer shelf life, sweeter flavor, and 20 days later harvest than Golden Delicious. Origin: Herault, France by A. Grard and O. Grard. Christmas Rose $\times$ Gradigold; USPP 22,974; 21 Aug. 2012. Fruit: globose with no ribbing, 75 to $80 \mathrm{~mm}$ diameter $\mathrm{x} 90$ to $100 \mathrm{~mm}$ height, $40 \%$ to $70 \%$ purple-red blush and weak stripe overcolor on yellow-green ground color; juicy, moderately firm flesh with strong aroma and rich flavor, stores in refrigeration for 6 to 8 months. Tree: high vigor with semiupright habit and annual bearing on spurs and long shoots. 
Hesztia. Large, early season apple, suitable for fresh consumption or apple chip production with multiple disease resistance. Origin: Corvinus University of Budapest, Budapest, Hungary by M. Tóth, G. Ficzek, I. Király, S. Kovács, M. Hevesi, J. Halász, and Z. Szani. Prima O.P.; selected as MR-09. HortScience 47:1795-1800. Fruit: conic, $73 \mathrm{~mm}$ height $\mathrm{x} 84 \mathrm{~mm}$ diameter, moderate greasiness, $60 \%$ to $80 \%$ red blush and stripes over yellow-green ground color; flesh is crisp, very juicy, sweet-tart, should be stored above $2{ }^{\circ} \mathrm{C}$ to avoid internal disorders. Tree: medium vigor, long branches and spreading habit, bears fruit on spurs and long shoots, moderate precocity and productivity; resistance ( $V f / R v i \sigma)$ to apple scab, powdery mildew and fireblight (shoot infection).

Inored. Highly red colored, sweet, late maturing apple with long shelf life and scab resistance. Origin: Institut National de la Recherche Agronomique at Angers, France by C. Pitiot and F. Laurens. Pinova $\times$ X6398; USPP 22,794; 19 June 2012. Fruit: ellipsoid, 75-80 mm diameter with weak ribbing and crowning at calyx end; $75 \%$ to $100 \%$ red blush with weak striping over yellow-green ground color; sweet (13-15 ${ }^{\circ}$ Brix). Tree: medium vigor with spreading to weeping habit, susceptible to powdery mildew and resistant to apple scab via Vf (Rvi6) gene.

Monalisa. High coloring fruit with low chilling requirement and resistance to scab, glomerella leaf spot and spider mite. Origin: Epagri/Cacador Experimental Station at Cacador, Santa Catarina, Brazil by Fr. Denardi and A.P. Camilo. Gala $\times$ Malus 4; USPP 23,003; 4 Sept. 2012. Fruit: conical with absent to weak ribbing and crowning, $74 \mathrm{~mm}$ diameter, $80-100 \%$ blush red-purple overcolor, yellow-white ground color and moderate greasiness; firm, fine flesh with weak aroma, medium sugar, medium to high acidity and juiciness. Tree: medium vigor with ramified, spreading habit; resistance to scab (Vf/Rvi6), leaf spot and bitter rot caused by Colletotrichum gloeosporioides, and red spider mite [Panonychus ulmi (Koch)].

NC1. Late maturing, attractive offspring of Cox's Orange Pippin with long shelf life. Origin: Staplehurst, Kent, United Kingdom by J.R. Breach. Cox's Orange Pippin O.P., with Golden Delicious indicated as putative male parent based on DNA markers; USPP 22,858; 17 July 2012. Fruit: conical, absent to weak ribbing and moderate crowing at calyx end, diameter $74 \mathrm{~mm}$, skin has moderate greasiness and absent to weak bloom, $40 \%$ to $60 \%$ orange-red blush overcolor with well defined stripes, russet in stem end cavity; medium coarse, firm, highly aromatic flesh with high acid and soluble solids content ( $14^{\circ}$ Brix). Tree: quite vigorous, upright habit, some tolerance to Nectria canker and medium susceptibility to scab and powdery mildew.

Newell-Kimzey (Airlie Red Flesh). Red-fleshed apple with light green to yellowish skin with light colored dots. Some reddening of skin on some fruits. Ripens mid season. Origin: Airlie, Oregon chance seedling growing by Lucky Newell's orchard in 1960, discovered anew by L. Kimzey Jr. in approximately 1985 . Fruit: oblong to conical 55-75 $\mathrm{mm}$ diameter x 60-80 $\mathrm{mm}$ height; flesh light pink to deep red, firm, moderately dense, moderately acidic, mildly sweet, tart, fragrant overtones such as strawberry-lemon. Tree: Moderately vigorous with pink to light red petals at bloom.

Picnic. Similar to Fuji but with smaller, more conical fruit that matures one month earlier. Origin: The Rural Development Administration, Republic of Korea, Gyeongbuk, Korea by S.I. Kwon, M.J. Kim, P.N. Paek, and J.C. Nam. Fuji × Sansa; USPP 24,136; 7 Jan. 2014. Fruit: Conical, small (67 mm height x $76 \mathrm{~mm}$ diameter), red skin, firm flesh with high sweetness $\left(14.2^{\circ}\right.$ Brix $)$ and moderate acidity. Tree: upright-semi-spreading, resistant to bitter rot.

Plumac. Large, sweet, firm, late-season fruit on a tree with weeping growth habit. Origin: Upper Moutere, New Zealand by G. Plunkett. Chance seedling; USPP 23,418; 26 Feb. 2013. Fruit: globose-conical, slight asymmetry and crowning at calyx end; $73-79 \mathrm{~mm}$ diameter $\mathrm{x}$ $64-76 \mathrm{~mm}$ height, $85 \%$ to $95 \%$ red blush, mottle and weak stripe overcolor; flesh is crisp, juicy, moderately acidic, very firm and sweet; stores 4 to 5 months in ambient atmosphere refrigeration. Tree: medium to strong vigor with drooping to weeping, naturally feathered habit; bears annually on spurs and long shoots.

PremA17. Early season with blush yellow color and excellent texture and flavor. Origin: Plant and Food Research, Havelock North, New Zealand by A. White, assigned to Prevar Ltd. Selected from A045R13T007× A020R02T167; USPP 22,357; 20 Dec. 2011. Fruit: Globose, medium size ( $7.6 \mathrm{~cm}$ height), no ribbing or crowning, $25 \%$ red stripe and blush overcolor; crisp texture, medium juiciness, white flesh. Tree: medium vigor, spreading habit, bearing on spurs and tips.

PremA193. Attractive fruit with excellent texture and flavor ripening approximately one month after Royal Gala. Origin: Plant and Food Research, Havelock North, New Zealand by A. White, assigned to Prevar Ltd. Selected from Braeburn $\times$ Tenroy (aka Royal Gala); USPP 22,357; 20 Dec. 2011. Fruit: globose conical with no ribbing or crowning at calyx end, $80 \mathrm{~mm}$ diameter $\mathrm{x} 78 \mathrm{~mm}$ height, approximately $95 \%$ red stripe and blush over yellow ground color; crisp flesh with medium juiciness. Tree: high vigor, spreading habit, bearing on spurs and shoots, flowering in midseason.

Premier Star. Limb mutation of Imperial Gala distinguished by having greater and brighter red blush. Origin: Hope, New Zealand by S. Buck and A.G. Buck in 1999. USPP 22,949. 14 Aug 2012. Fruit: large; globose and conical, no ribbing, $75 \mathrm{~mm}$ diameter $\mathrm{x}$ $66 \mathrm{~mm}$ height; yellow green ground color with $70-90 \%$ bright red solid blush; flesh white; firm, crisp; sweet (12-13 ${ }^{\circ}$ Brix), mildly acid; excellent eating quality; ripens in February near Hope, Nelson, New Zealand. Tree: average vigor; ramified; spreading.

Rosmerta. Late-midseason, medium size fruit, alternative to Jonathan with multiple disease resistance. Origin: Corvinus University of Budapest, Budapest, Hungary by M. Tóth, G. Ficzek, I. Király, S Koavács, M. Hevesi, J. Halász, and Z. Szani. Selected as MR-03 from the cross All Red Jonathan $\times$ Prima made in 1992. HortScience 47:1795-1800. Fruit: conic, $60 \mathrm{~mm}$ height $\times 73 \mathrm{~mm}$ diameter, strong greasiness, nearly $100 \%$ dark red blush and faint stripes over yellow-green ground color; flesh is semi-firm, fine textured, subacid with weak aroma, can exhibit lenticel breakdown and Jonathan-spot disorders in storage. Tree: medium vigor, with strong central leader and spreading habit, bears fruit on both spurs and long shoots; precocious, annual bearing and highly productive; resistance $(\mathrm{Vf} /$ RviG) to apple scab, powdery mildew and fireblight (shoot infection)

Smerelda. Green fruit borne on a compact, easy to manage tree with scab resistance. Origin: Consorzio Italiano Vivaisti, San Giuseppe di Comacchio, Ferrara, Italy by M. Leis, A. Martinelli, F. Tagliani, D. Azzolini, P. Castagnoli, and A. Castagnoli. DA $85 \times$ B9-5; selected in 2005; USPP 24,137; 7 Jan. 2014. Fruit: Conic, $69 \mathrm{~mm}$ height and $81 \mathrm{~mm}$ diameter, smooth skin with green ground color with no overcolor; firm, crisp, juicy flesh moderate soluble solids (12.5 to $13.5^{\circ}$ Brix) and high acidity ( $8-9 \mathrm{~g} \cdot \mathrm{L}^{-1}$ malic acid). Tree: medium vigor with pyramidal, ramified form and spreading habit; precocious and annual bearing on long shoots and spurs.

Southfield. Limb mutation of Scifresh with greater amount and intensity of overcolor and earlier harvest date. Origin: Nelson, New Zealand by R.J.R. Hoddy. USPP 22,990; 28 Aug. 2012.

WA38. Large, firm, crisp, attractive late season fruit with excellent eating quality at harvest and out of long term storage. Origin: Washington State University Tree Fruit Research and Extension Center, Wenatchee, WA by K.M. Evans, B.H. Barritt, B.S. Konishi, L.J. Brutcher and C.F. Ross. Enterprise $\times$ Honeycrisp; crossed in 1997; selected in 2003. HortScience 47:1177-1179. Fruit: roundconic, $79 \mathrm{~mm}$ height $\times 84 \mathrm{~mm}$ diameter, $90 \%$ dark red-purple blush over green-yellow ground color; flesh is very crisp, firm and juicy, 
tart, mildly aromatic, very slow browning makes it suitable for packaged slices. Tree: medium to low vigor, upright spreading habit; precocious and moderately productive; moderate susceptibility to powdery mildew and fire blight.

\section{APRICOT AND PUBESCENT-SKINNED PRUNOPHORA HYBRIDS}

Craig A. Ledbetter, USDA-ARS San Joaquin Valley Agricultural Sciences Center, Parlier, CA

\section{Apricots}

Clutha Summer. Orange-fleshed, semi-clingstone apricot with superbly flavored firm flesh. Origin: Clyde, Otago, New Zealand, by M.T. Malone and A.E. Nixon. Goldstrike O.P.; selected 2002, tested as D14/1; USPP 22,716; 8 May 2012. Fruit: symmetrical, ovate, 120-150 g; semi-clingstone; flesh orange, skin blush 25 to $85 \%$ of fruit surface; fruit surface smooth with minimal pubescence; texture fine grained and consistently dense, melting texture; flavor sweet with distinct apricot aroma; juice reported at $\mathrm{pH}$ 4.6. Tree: vigor medium; growth habit upright to spreading; productivity high; flowers self-compatible.

\section{Pubescent-Skinned Prunophora Hybrids}

Betty-cot. Attractive orange-skinned freestone interspecific with good flavor, firm flesh and good eating quality. Origin: Modesto, CA, by G.N. Zaiger, L.M. Gardner, and G.G. Zaiger. 160LH550 O.P.; selected 2001; USPP 22,648; 17 Apr. 2012. Fruit: slightly elongated, slightly flatted inward toward suture plane, $108 \mathrm{~g}$; freestone; flesh orange, texture meaty; fibers few, small, tender; aroma moderate; no tendency to crack. Tree: vigorous; growth habit semi-spreading; production regular, no alternate bearing observed; flowers selfcompatible; chill requirement $750 \mathrm{~h}$ at or below $7{ }^{\circ} \mathrm{C}$.

Macy-cot. Vigorous upright self-fertile interspecific with uniformlysized orange-fleshed fruit of good eating and shipping quality. Origin: Modesto, CA, by G.N. Zaiger, L.M. Gardner, and G.G. Zaiger. 25ED21 × 36GH296; selected 2003; USPP 22,730; 15 May 2012. Fruit: nearly globose, slightly elongated and compressed in suture plane, $159 \mathrm{~g}$; freestone; flesh orange, texture firm, meaty; fibers few, small, tender; aroma moderate; firmer than most commercial apricots, eating quality good. Tree: vigorous; growth habit upright; bearing regular, productive; flowers self-compatible; chill requirement $700 \mathrm{~h}$ at or below $7{ }^{\circ} \mathrm{C}$.

Bella Jewel. Regular and productive bearer of red-skinned medium to large sized fruit of very good flavor and eating quality. Origin: Modesto, CA, by G.N. Zaiger, L.M. Gardner, and G.G. Zaiger. 279LV182 × Bella Sun; selected 2009; USPP 23,106; 16 Oct. 2012. Fruit: nearly globose to slightly elongated, $125 \mathrm{~g}$; clingstone; flesh red, texture firm, smooth; fibers few, small, tender; slight tendency to crack; eating quality very good. Tree: vigorous; growth habit upright; bearing regular, productive; flowers self-incompatible; chill requirement $450 \mathrm{~h}$ at or below $7^{\circ} \mathrm{C}$.

Kylese. Orange-skinned freestone interspecific with good fruit size uniformity, flavor and eating quality. Origin: Modesto, CA, by G.N. Zaiger, L.M. Gardner, and G.G. Zaiger. 278LP84 × 11M30; selected 2007; USPP 23,123; 23 Oct. 2012. Fruit: slightly elongated, 102 g; freestone; flesh orange, texture firm; fibers few, small, tender; aroma moderate; no tendency to crack; eating quality good. Tree: vigorous; growth habit upright; bearing regular, productive; flowers selfcompatible; chill requirement $450 \mathrm{~h}$ at or below $7{ }^{\circ} \mathrm{C}$.

Country cot. Productive and regular bearer of large orange-fleshed firm fruit with good eating, handling and shipping qualities. Origin: Modesto, CA, by G.N. Zaiger, L.M. Gardner, and G.G. Zaiger.
178LM586 × 12ZB628; selected 2005; USPP 23,695; 2 July 2013. Fruit: elongated, slightly flatter toward suture plane, $140 \mathrm{~g}$; freestone; flesh orange, texture firm, meaty, fibers few small tender; aroma slight; no tendency to crack; eating quality good. Tree: vigorous; growth habit upright; bearing regular, productive; flowers partially self-fertile, pollinizer recommended; chill requirement 350 hours $h$ at or below $7{ }^{\circ} \mathrm{C}$.

\section{APRICOT ROOTSTOCK}

Thomas G. Beckman, USDA-ARS Southeastern Fruit and Tree Nut Res. Lab. Byron, GA

Densipac. Compatible with some apricot varieties. Described under Peach Rootstock.

HBOK 27. Compatible with apricot varieties. Described under Peach Rootstock.

\section{BLACKBERRY}

Chad E. Finn, USDA-ARS, Horticultural Crops Research Laboratory, Corvallis, OR

John R. Clark, Department of Horticulture, University of Arkansas, Fayetteville, AR.

A-1960 (Heaven Can Wait ${ }^{\mathrm{TM}}$ ). Thornless, erect, floricane-fruiting blackberry with excellent flavor for home garden or local market use. Origin: University of Arkansas Division of Agriculture, Fayetteville, AR by J.R. Clark and J.N. Moore. A-1583 × A-1482; crossed 1991; selected 1994; tested as A-1960; introd. 2012; USPP applied for. Fruit: elongated to conical; medium, 5-6 g; uniform drupelet size; attractive; very good flavor; soluble solids usually $11-12{ }^{\circ} \mathrm{Brix} ; \mathrm{pH} 3.2$ titratable acidity $15.6 \mathrm{~g} \cdot \mathrm{L}^{-1}$; ripens mid-early on floricanes, $4 \mathrm{~d}$ before to near Ouachita in Arkansas; moderate postharvest potential and not highly recommended for commercial shipping. Plant: erect; thornless; vigorous; limited anthracnose (Elsinoe veneta) and no orange rust (Gymnoconia nitens) observed; floricanes hardy to $-17{ }^{\circ} \mathrm{C}$ or possibly lower temperatures; productive with moderate to high yield potential.

A-2312 (Stella). Thorny, erect, floricane-fruiting blackberry with excellent flavor for commercial use. Origin: University of Arkansas Division of Agriculture, Fayetteville, AR by J.R. Clark. APF-1 $\times$ A-2001; crossed 2000; selected 2002; tested as A-2312; introd. 2012; USPP applied for. Fruit: elongated; large, $10 \mathrm{~g}$; uniform drupelet size; attractive; very good flavor; soluble solids usually $11-12{ }^{\circ} \mathrm{Brix}$; $\mathrm{pH} 2.8$ titratable acidity $6.8 \mathrm{~g} \cdot \mathrm{L}^{-1}$; ripens mid-early on floricanes, $3 \mathrm{~d}$ before Ouachita in Arkansas; very good postharvest potential and recommended for commercial shipping. Plant: erect; thorny; vigorous; limited anthracnose (Elsinoe veneta) and no orange rust (Gymnoconia nitens) observed; downy mildew (Peronospora sparsa) resistance observed in Guatemala; floricanes hardy to $-17{ }^{\circ} \mathrm{C}$ or possibly lower temperatures; has performed well in a low-chill environment; productive with high yield potential.

APF-77 (Black Magic ${ }^{\mathrm{TM}}$ ). Thorny, primocane-fruiting, erect blackberry recommended for home garden use. Origin: University of Arkansas Division of Agriculture, Fayetteville, AR by J.R. Clark. Prime-Jim ${ }^{\circledR}$ (APF-12) $\times$ Arapaho; crossed 2001; selected 2003; tested as APF-77; introd. 2010; USPP applied for. Fruit: conical to round; large, 7-8 g; uniform drupelet size; attractive; good flavor; soluble solids usually $10^{\circ}$ Brix or more; $\mathrm{pH} 3.5$, titratable acidity $5.0 \mathrm{~g} \cdot \mathrm{L}^{-1}$; ripens early on floricanes, in early June in Arkansas, near APF-45 (Prime-Ark ${ }^{\circledR} 45$ ); on primocanes ripens early, mid July in Arkansas and later in cooler locations and can fruit until frost; fruit not recommended for shipping as storage potential is limited for postharvest handling for multiple days, but should be suitable for home garden or local market use. Plant: erect; thorny; primocane fruiting; vigorous; limited anthracnose (Elsinoe veneta) and no 
orange rust (Gymnoconia nitens) observed; floricanes hardy to $-17^{\circ} \mathrm{C}$ or possibly lower temperatures; productive with high yield potential on floricanes and good primocane productivity in moderate summer temperature climates; has been observed to have more heat tolerance in primocane fruiting than Prime-Jim ${ }^{\circledR}$ and Prime-Jan ${ }^{\circledR}$ in Arkansas.

APF-153 (Prime-Ark ${ }^{\circledR}$ Freedom). Thornless, primocane-fruiting, erect blackberry recommended for home garden or local market use. Origin: University of Arkansas Division of Agriculture, Fayetteville, AR by J.R. Clark. A-2301 × APF-49T; crossed 2004; selected 2007; tested as APF-153T; introd. 2013; USPP applied for. Fruit: elongated to slightly conical; very large, 9-15 g depending on cane fruit is born on and climatic conditions; uniform drupelet size; attractive; good flavor; soluble solids usually $10 \%$ or more; ripens very early on floricanes, 7-9 d before Natchez and APF-45 (Prime-Ark ${ }^{\circledR} 45$ ); on primocanes ripens early, early to mid July in Arkansas and 2 weeks before APF-45 (Prime-Ark ${ }^{\circledR} 45$ ) and later in cooler locations and can fruit until frost; fruit not recommended for shipping as storage potential is limited for postharvest handling for multiple days, but should be suitable for home garden or local market use. Plant: erect; thornless; primocane fruiting; vigorous; limited anthracnose (Elsinoe veneta) and no orange rust (Gymnoconia nitens) observed; floricanes hardy to $-17{ }^{\circ} \mathrm{C}$ or possibly lower temperatures; productive with moderate yield potential on floricanes and good primocane productivity in moderate summer temperature climates.

Black Magic ${ }^{\mathrm{TM}}$. See APF-77.

Columbia Star. Thornless trailing blackberry with firm uniformly shaped and sized fruit that are machine harvestable and comparable to Marion for processed fruit quality. Origin: USDA-ARS, Corvallis, OR, by C.E. Finn, B.C. Strik, B.M. Yorgey, J. Lee, and R.R. Martin. NZ 9629-1 × ORUS 1350-2; crossed 2005; selected 2008; tested as ORUS 3447-1; introd. 2013; USPP applied for. Fruit: conic; uniformly sized, shaped and arranged drupelets; uniform, attractively shaped and rated better than Marion; large, $7.0 \mathrm{~g}$; bright, glossy black; machine harvests easily; outstanding fresh fruit flavor; sweet with good acidic balance and aroma typical of western blackberries and with noticeable raspberry aromatic notes; fruit texture comparable to Marion and less crunchy than Chester Thornless; good soluble solids $12.4^{\circ}$ Brix; $\mathrm{pH} 3.2$, and titratable acidity $15.0 \mathrm{~g} \cdot \mathrm{L}^{-1}$ as citric; ripens in similar season to Marion with a more compact season; firm enough to be sold fresh in regional markets. Plant: trailing; thornless with the Lincoln Logan source of thornlessness; vigorous; high yield; less susceptible to UV damage then Marion' or Black Diamond; medium lateral length; machine harvests easily with very clean fruit; not particularly susceptible to septoria leaf spot (Mycosphaerella rubi) and purple blotch (Septocyta ruborum); hardiness not well tested but in a planting that experienced a decline in minimum temperature from $8{ }^{\circ} \mathrm{C}$ on 16 Nov. to $-12{ }^{\circ} \mathrm{C}$ on 24 Nov. it had injury but was scored as having less cane and bud injury than Marion or Black Diamond.

DrisBlackThree. Spiny, upright to semi-upright blackberry that breaks bud early. Origin: Driscoll Strawberry Associates, Inc., Gilroy, CA, by G.R. Sills, A.M. Pabon, and C.D. Fear. Driscoll Carmel $\times$ Zorro; selected 2003; USPP 23,725; 9 July 2013. Fruit: medium size, $6.8 \mathrm{~g}$; oblong; soluble solids $11.2^{\circ} \mathrm{Brix}$; early bud break and ripening. Plant: semi-upright; thorny; high fruit productivity.

Driscoll's $^{\circledR}$ Monica $^{\text {TM. }}$. See DrisBlackThree.

\section{Heaven Can Wait ${ }^{\mathrm{TM}}$. See A-1960.}

HJ-7. Thorny, medium size, early fruiting, trailing blackberry. Origin: Plant Sciences, Inc., Santa Cruz Co., CA, by H.A. Johnson. Eaton $\times$ Obsidian; crossed 2005; selected 2007; tested as Z26.7; introd. 2010; USPP applied for. Fruit: consistently medium sized; ovate to slightly oblong; high gloss; early production peak in mid-May with production continuing through June; texture and flavor good. Plant: trailing with thin diameter canes; excellent lateral strength; laterals of medium length; shows no susceptibility to rust or powdery mildew in Santa Cruz Co., CA.

Ningzhi 1. Trailing blackberry with few cane prickles. Origin: Institute of Botany, Jiangsu Province and the Chinese Academy of Sciences, by Weilin Li, Wenlong Wu, et al., Nanjing, China. Primocane mutant of Boysenberry; mutated 2002; selected 2004; released 2010. Fruit: medium, $6 \mathrm{~g}$; soluble solids $10.95{ }^{\circ} \mathrm{Brix}$; excellent flavor; early ripening, ripens from late-May to mid-June with a cropping period of 22-24 d. Plant: trailing; thornless; high yield with $15.35 \mathrm{t} \cdot \mathrm{ha}^{-1}$.

Ningzhi 2. Thornless blackberry with early-ripening. Origin: Institute of Botany, Jiangsu Province and the Chinese Academy of Sciences, by Weilin $\mathrm{Li}$, Wenlong Wu, et al., Nanjing, China. Triple Crown $\times$ Navaho; crossed 2002; selected 2004; released 2011. Fruit: medium, $4.88 \mathrm{~g}$; oblong; bright black; sweet, soluble solids $11.95^{\circ} \mathrm{Brix}$; ripens from early June to mid-July with a cropping period of 22-24 d. Plant: semi-upright; thornless; strong growth; high yield with $15-16 \mathrm{t} \cdot \mathrm{ha}^{-1}$.

Osage. Thornless, erect, floricane-fruiting blackberry with excellent flavor and postharvest handling potential. Origin: University of Arkansas Division of Agriculture, Fayetteville, AR by J.R. Clark. A-1719 × A-2108; crossed 2000; selected 2003; tested as APF-2362; introd. 2012; USPP applied for. Fruit: conical to round; medium, 5-6 g; uniform drupelet size; attractive; very good flavor; soluble solids usually $10-12^{\circ} \mathrm{Brix} ; \mathrm{pH} 3.2$ titratable acidity $5.0 \mathrm{~g} \cdot \mathrm{L}^{-1}$; ripens mid-early on floricanes, $3 \mathrm{~d}$ before Ouachita in Arkansas; excellent postharvest potential with limited leakiness and reddening and recommended for commercial shipping. Plant: erect; thornless; vigorous; limited anthracnose (Elsinoe veneta) and no orange rust (Gymnoconia nitens) observed; floricanes hardy to $-17{ }^{\circ} \mathrm{C}$ or possibly lower temperatures; productive with high yield potential on floricanes.

\section{Prime-Ark ${ }^{\circledR}$ Freedom. See APF-153.}

Reuben. Thorny, primocane-fruiting blackberry. Origin: Hargreaves Plants, Spalding, Lincolnshire, UK by J.R. Clark and J. Fairlie. A-2292T $\times$ APF-44; crossed 2005; selected 2006; tested as HPB3; introd. 2010; USPP 23,497; 26 Mar. 2013. Fruit: oblong to blocky; very large, up to $14.5 \mathrm{~g}$; uniform drupelet size; attractive; good flavor; soluble solids $11.5^{\circ}$ Brix; ripens late season on primocanes and fruits until frost fruit or cold conditions terminate ripening; recommended for commercial markets for shipping as well as local market and home garden use. Plant: erect; thorny; primocane fruiting; vigorous; productive.

Stella. See A-2312.

\section{BLUE HONEYSUCKLE}

\section{Kim E. Hummer, USDA ARS National Clonal Germplasm Repository, Corvallis, OR}

Robert H. Bors, Department of Plant Sciences, University of Saskatchewan, Saskatoon, Canada

Aurora. Early ripening, cold hardy, easily harvested, mildew resistant, blue honeysuckle for mechanical harvest. Origin: University of Saskatchewan, Saskatoon, Canada, by R. Bors. Solovey $\times$ MT46.55; crossed 2007; selected 2010; tested as 22-6-26.5; introd. 2012; Plant Breeder's Rights Certification with Agriculture Canada Pending. Fruit: dark blue with white bloom; somewhat pointed pear shape; early ripening, before Borealis; flavor tart-sweet; $1.9 \mathrm{~g}$ per berry; recommended for machine harvesting for processing. Plant: 
cold hardy; upright and spreading; highly resistant to mildew; highly productive; pollinizer for Borealis, Tundra, and the Indigo series.

\section{BLUEBERRY}

\section{Mark K. Ehlenfeldt, USDA-ARS, Genetic Improvement of Fruits and Vegetables Laboratory, Beltsville, MD}

Blue Ribbon. High-yielding early/midseason northern highbush blueberry for the fresh market. Origin: Fall Creek Farm and Nursery Lowell, OR, by D. Brazelton and A. Wagner. Toro $\times$ G-344; crossed 2002; selected 2005; tested as ZF05-009; introduced 2011; US Patent Application US 2013/0239265 P1. Fruit: large to medium; light blue; spherical or slightly flattened; typically sweet with juicy and crispy texture; good post-harvest storage; ripens between Duke and Draper. Plant: good vigor; spreading growth habit with long arching branches; strong leafing; long laterals; self-fertile.

Blue Silk. Highbush blueberry with late-season production. Origin: New Zealand Institute for Plant and Food Research, Limited, Ruakura Research Centre, Hamilton, New Zealand and Wilhelm Dierking, Beerenobst, Germany, by J. Scalzo and N. Patel. Elliott $\times$ Puru; selected 2008; tested as ZDM035; USPP and EU PVR applied for. Fruit: medium to large, $2.2 \mathrm{~g}$; medium blue; oblate with small dry scar; medium firmness; balanced flavor. Plant: upright; medium sized.

\section{Blueberry Glaze. See ZF08-095.}

Bobolink $^{\mathrm{TM}}$. See FL03-291.

Cargo. High-yielding mid- to late-season northern highbush blueberry. Origin: Fall Creek Farm and Nursery Lowell, OR, by D. Brazelton, A. Wagner. Bluegold $\times$ Ozarkblue; crossed 2002; selected 2005; tested as ZF05-157; introduced 2011; US Patent Application US 2013/0239260 P1. Fruit: medium size; light blue; round; firm; mild flavor; juicy texture; fruit releases well; high yielding; ripens in Liberty season. Plant: upright growth habit with narrow crown; extremely vigorous; recommended for machine harvest; self-fertile.

\section{Chickadee $^{\mathrm{TM}}$. See FL04-235.}

Cipria. Southern highbush blueberry with early to mid-season production. Origin: New Zealand Institute for Plant and Food Research, Limited, Ruakura Research Centre, Hamilton, New Zealand and Wilhelm Dierking, Beerenobst, Germany, by J. Scalzo and N. Patel. Summit O.P.; selected 2002; introduced 2012; tested as RH48; USPP and EU PVR applied for. Fruit: oblate; medium to large, $2.2 \mathrm{~g}$; medium blue; medium firmness. Plant: semi-upright to spreading; medium sized; vigorous open bush.

Clockwork. Mid-season northern highbush blueberry for the process market. Origin: Fall Creek Farm and Nursery Lowell, OR, by D. Brazelton, A. Wagner. Reka $\times$ US 645; crossed 2002; selected 2005; tested as ZF05-029; introduced 2011; US Patent Application US 2013/0239264 P1. Fruit: medium size; medium blue; slightly flattened; large, shallow calyx; aromatic blueberry flavor; concentrated ripening; ripens in Draper season. Plant: extremely upright growth habit; narrow crown; excellent machine harvest potential.

Cosmopolitan. Highbush blueberry with mid-season production, ideal for home garden. Origin: New Zealand Institute for Plant and Food Research, Limited, Ruakura Research Centre, Hamilton, New Zealand and Wilhelm Dierking, Beerenobst, Germany, by J. Scalzo and N. Patel. Nui $\times$ Darrow; selected 1999; tested as F100, introduced 2012; EU PVR applied for. Fruit: large, 2.2 to 2.8 g, oblate, medium to dark color and medium firmness. Plant: medium vigor; semiupright growth; high yielding; productive; flowering and production contemporary to Nui; requires very little pruning and management in the field and is suitable for home garden.

Eboshi Ao (Eboshi $=$ a mountain in the Nagano prefecture, Ao $=$ blue). Late-season northern highbush blueberry with very good eating quality. Origin: Fruit Tree Nurseries, Komacihen Co., Nakagawa-mura, Nagano Pref., Japan by T. Matuzawa. Lateblue O.P., 1982; selected 1990; introduced 2008; registered as No. 16974 by the Seedlings Law of Japan. Fruit: large to very large; oblate; light blue; excellent firmness, scar, and flavor; requires cross-pollination; ripens late season, before Lateblue; good postharvest shelf-life; suitable for fresh market. Plant: medium vigor; upright; height $150-170 \mathrm{~cm}$; flowers before Lateblue; moderate productivity; moderate soil adaptability.

FL03-291 $\left(\right.$ Bobolink $\left.^{\mathrm{TM}}\right)$. Mid-season southern highbush cultivar with excellent vigor and survival. Origin: University of Florida, by P.M. Lyrene. FL00-28 × FL98-363; crossed 2000; selected 2003; tested as FL03-291; introduced 2009; USPP 21,377 P2. Fruit: large; light blue; good firmness and picking scar; sweet flavor when fruit first turns blue; ripens with Star. Plant: vigorous, somewhat spreading habit; excellent survival in the field; readily propagated by softwood cuttings; requires cross-pollination; chilling requirement $300 \mathrm{~h}$.

FL04-235 (Chickadee ${ }^{\mathrm{TM}}$ ). Very-early southern highbush blueberry with a low chilling requirement. Origin: University of Florida, by P.M. Lyrene. FL98-409 × C97-390; crossed 2001; selected 2004; tested as FL04-235; introduced 2009; USPP 21,376 P2. Fruit: large; excellent scar, firmness, and flavor; ripens extremely early with $50 \%$ ripe fruit by 15 Apr. in Gainesville, FL. Plant: vigorous, upright habit; canopy is not dense; medium field survival; susceptible to blueberry necrotic ring blotch virus; flowers early; readily propagated by softwood cuttings; requires cross-pollination; chilling requirement 100-200 h.

FL05-107 $\left(\right.$ Vireo $\left.^{\mathrm{TM}}\right)$. Early southern highbush blueberry with a low chilling requirement and large fruit. Origin: University of Florida, by P.M. Lyrene. FL02-13 × Farthing; crossed 2002; selected 2005; tested as FL05-107; introduced 2009; USPP 21,375 P2. Fruit: large; excellent scar; light blue; very good firmness; tart flavor before fully ripe; ripens very early with $50 \%$ ripe fruit by $15 \mathrm{Apr}$. in Gainesville, FL. Plant: vigorous, somewhat spreading growth habit; prolific early-spring leafing; medium field survival; flowers early; readily propagated by softwood cuttings; requires cross-pollination; chilling requirement $<300 \mathrm{~h}$.

FL05-627 (Raven $\left.^{\text {TM }}\right)$. Very large southern highbush blueberry with excellent flavor and firmness. Origin: University of Florida, by P.M. Lyrene. FL01-26 × Windsor; crossed 2001; selected 2005; tested as FL05-627; introduced 2009; USPP 21,374 P2. Fruit: extremely large; medium blue; very good scar and firmness relative to size; sweet flavor; ripens after Star in a concentrated period. Plant: moderately vigorous, upright habit; good survival in the field; blooms later than Star; readily propagated by softwood cuttings; moderately susceptible to blueberry leaf scorch (Xylella fastidiosa); requires crosspollination; chilling requirement $300 \mathrm{~h}$.

Fuku-berry $(\mathrm{Fuku}=$ happiness $)$. Extremely-late-season rabbiteye blueberry with larger fruit size. Origin: Blueberry grower, NerimaWard, Tokyo Metropolis, Japan, by T. Fukuda. (Woodard $\times$ Tifblue) O.P., 1997; selected 2001; introduced 2008; registered as No. 16778 by the Seedlings Law of Japan. Fruit: larger than Tifblue; roundoblate; very light blue; firm; scar very small and dry; very good postharvest keeping quality; requires cross-pollination; poor abscission layer; ripens late-season to very late; very long harvesting period (late July to late September at Tokyo); edible quality is rich and excellent for pick-your own farming and fresh market. Plant: very vigorous; spreading; height $200-300 \mathrm{~cm}$; requires summer pruning to control strong shoots; bloom time similar to Tifblue; broad soil adaptation like Tifblue; high productivity. 
Georgia Dawn ${ }^{\text {TM }}$. See TH-819.

Jam Session. See ZF05-196.

Jelly Bean. See ZF06-179.

Jinva Ao (Jinva $=$ a mountain in the Nagano prefecture, Ao $=$ blue) . Early-season highbush blueberry suitable for pick-your-own farming. Origin: Fruit Tree Nurseries, Komacihen Co., Nakagawa-mura, Nagano Pref., Japan by T. Matuzawa. Spartan O.P., 1992; selected 1995; introduced 2008; registered as No. 16970 by the Seedlings Law of Japan. Fruit: very large (to medium in later part of season); oblate/flattened; medium blue; scar medium; slightly soft firmness with fewer seeds; juicy; requires cross-pollination; ripens late, a few days after Spartan; excellent flavor; good for pick-your-own farming. Plant: moderately vigorous; upright; height $120-150 \mathrm{~cm}$; flowers similar to Spartan; yield medium; wider soil adaptability than Spartan.

\section{Last Call. See ZF06-288.}

Lielogu. Mid-season, cold-resistant, rabbiteye blueberry. Origin: National Botanic Garden, Salaspils, Latvia, by A. Ripa. Delite $\times$ Woodard; crossed 1988; selected 1995; introduced 2010. Fruit: large, light blue, round flattened shape, medium firmness, small, dry pedicel scar. Plant: vigorous, upright, high-yielding, resistant to anthracnose (Geosporium frufructigenum) and fire blight (Erwinia amylovora).

Nocturne. Winter-hardy rabbiteye-type blueberry with ornamental fruit and superior quality. Origin: U.S. Department of Agriculture, Agricultural Research Service, Marucci Center for Blueberry \& Cranberry Research and Extension, Chatsworth, NJ, by M.K. Ehlenfeldt. US $874 \times$ Premier; crossed 1993; selected 1996; tested as US 1056; introduced 2012; US Plant Patent applied for. Fruit: medium to large (up to $2.0 \mathrm{~g}$ ); dark (gunmetal black); sweet ( $\sim 13{ }^{\circ}$ Brix); interesting flavor; ripens late-midseason to late season; fair scar; average firmness; only fair postharvest storage; unripe fruit is a vivid, red-orange. Plant: vigorous; upright; slightly spreading; highbush-rabbiteye intermediate-type plant with glossy green foliage; winter hardiness comparable to northern highbush cultivars; late flowering; reliably productive under NJ conditions; probable BRRSV resistance.

Ocean Blue. Outstanding quality, mid-season rabbiteye blueberry. Origin: The New Zealand Institute for Plant and Food Research, Ltd., Ruakura Research Centre, Hamilton, New Zealand, by N. Patel. Centurion $\times$ Rahi; selected 2000; tested as F107; introduced 2008; USPP 21,735 P3, NZ PVR 3036. Fruit: medium; oblate; medium blue; medium to firm; outstanding quality with little grittiness. Plant: upright; medium to strong vigor; flowering and cropping contemporary with Rahi; medium to high yield.

Overtime. Late season rabbiteye blueberry with excellent flavor Origin: Fall Creek Farm and Nursery Lowell, OR, by D. Brazelton and A. Wagner. Centurion $\times$ Powderblue; crossed 1999 in a joint effort with HortResearch, New Zealand; selected 2006; tested as ZFK-218; introduced 2011; US Patent Application US 2013/0239262 P1. Fruit: medium to large size; light blue; round with a small, dry picking scar; pleasant, sweet flavor; very little grittiness or seediness for a rabbiteye. Plant: fairly upright; good tolerance to bacterial canker caused by Pseudomonas syringae; requires cross-pollination.

Peach Sorbet. See ZF06-043.

Perpetua. Ornamental refruiting blueberry with spring and summer crops of small berries on a compact bush with attractive foliage. Origin: USDA-ARS, Corvallis, OR, by C.E. Finn, B.C. Strik, and R.R. Martin. O.P. seedling of CVAC 45 (PI 296412, wild Maine highbush); selected 2005; tested as ORUS 61-1; introduced 2012; US Patent Application US 2013/0239266 P1. Fruit: small, 1.2 g; uniform, round; medium blue; attractive calyx; moderately soft; mild flavor; wet picking scar; $1^{\text {st }}$ crop ripens earlier than Duke's and $2^{\text {nd }}$ crop in early-mid Aug. Plant: moderate vigor; compact; attractive, extremely dark green, glossy leaves borne on upright shoots.

Pink Icing. See ZF06-079.

Raven $^{\text {TM }}$. See FL05-627.

Rocio. Very early ripening blueberry, extremely firm with excellent acid-sweetness balance. Origin: University of Florida, by P.M. Lyrene, A. Abad Alamo, and J.U. Hayler Lopez. FL 96-24 × FL 953; crossed 1996; selected in Almonte, Huelva, Spain 2001; tested as SO1-29-01; introduced 2009; USPP 20,374 P2. Fruit: violet-blue; slightly flattened shape; extremely firm; excellent acid-sweetness balance; ripens early-season. Plant: flowers very early; vase-shaped to generally upright growth habit with evergreen foliage; self-fertile; low chilling requirement.

Romero. Very early ripening blueberry amenable to machine harvest. Origin: University of Florida, by P.M. Lyrene, A. Abad Alamo, and J.U. Hayler Lopez. FL 95-3 × Star; crossed 1996; selected in Almonte, Huelva, Spain 2001; tested as SO1-18-12; introduced 2009; USPP 20,373 P2. Fruit: dark blue; slightly flattened; pleasant acid blueberry flavor; ripens very early-season. Plant: flowers very early; strong, vigorous, generally upright growth habit with evergreen foliage; self-fertile and an excellent pollen producer; low chilling requirement.

Salaspils Izturīgā. Mid-season, cold-resistant, rabbiteye blueberry. Origin: National Botanic Garden, Salaspils, Latvia, by A. Ripa. Tifblue O.P., 1987; selected 1993; introduced 2010. Fruit: medium large; dark blue; round flattened shape; good quality; medium firmness; small, dry pedicel scar. Plant: vigorous; upright; highyielding; resistant to anthracnose (Gleosporium fructigenum) and fire blight (Erwinia amylovora).

Sweetcrisp. Southern highbush blueberry with an extremely firm, crisp fruit texture. Origin: University of Florida, by P.M. Lyrene. Southern Belle $\times$ FL95-3; crossed 1996; selected 2000; tested as FL00-59; introduced 2005; USPP 20,027 P3. Fruit: medium to large; light blue; good picking scar and very sweet flavor; extremely firm, crisp texture that crunches at first bite; ripens with Star; excellent postharvest storage ability. Plant: vigorous, with very early spring leafing; excellent survival in the field; readily propagated by softwood cuttings; requires cross-pollination; chilling requirement $300 \mathrm{~h}$.

T-959 $\left(\operatorname{Titan}^{\mathrm{TM}}\right)$. Very-large-fruited, high-yielding rabbiteye blueberry. Origin: University of Georgia by D.S. NeSmith. T-460 $\times$ FL 80-11; crossed 2002; selected in 2005; introduced in 2011; US Plant Patent applied for. Fruit: very large, 3.0 to $3.5 \mathrm{~g}$; medium- to lightblue; medium, dry picking scar; excellent firmness; good flavor; ripens with Alapaha and Premier; susceptible to rain cracking. Plant: very vigorous; upright; high yielding; flowers with Alapaha, Premier, and Vernon; estimated chilling requirement $500-550 \mathrm{~h}$; suitable for fresh market and machine harvest; propagation by softwood cuttings; cross-pollination with other cultivars of similar bloom times highly recommended.

TH-819 (Georgia Dawn ${ }^{\text {TM }}$ ). Very-early-season southern-highbush blueberry. Origin: University of Georgia, by D.S. NeSmith. Star $\times$ Bladen; crossed 1998; selected in 2001; introduced in 2012; US Plant Patent applied for. Fruit: medium- to medium-large, 1.4 to $1.8 \mathrm{~g}$; medium light-blue color; small, dry picking scar; good firmness and flavor; ripens 7-10 days earlier than Star. Plant: vigorous; upright bush with a narrow crown; flowers 7-10 days earlier than Star; frost protection strongly recommended; yield comparable to Star when frost protected; concentrated ripening; good leafing; estimated chilling 
requirement $\leq 350$ hours; suitable for fresh market and likely machine harvestable; propagation easily accomplished using softwood cuttings; self-fertile, but Rebel or Emerald recommended for cross-pollination.

Titan $^{\mathrm{TM}}$. See T-959.

Top Shelf. Mid-season, mid-chill, jumbo blueberry for the fresh market. Origin: Fall Creek Farm and Nursery Lowell, OR, by D. Brazelton and A. Wagner. Magnolia $\times$ Draper; crossed 2004; selected 2007; tested as ZF07-070; introduced 2011; US Patent Application US 2013/0239261 P1. Fruit: very large; light blue; very firm; round, slightly flattened; strong tropical flavors and juicy texture; ripens in Draper season. Plant: vase-shaped; upright; strong vigor.

Utsugi Ao (Utsugi = a mountain in the Nagano prefecture, Ao=blue). Early-season northern highbush blueberry with excellent eating quality. Origin: Fruit Tree Nurseries - Komacihen Co., Nakagawamura, Nagano Pref., Japan, by T. Matuzawa. Spartan O.P., 1992; selected 2000; introduced 2008; registered as No. 16971 by the Seedlings Law of Japan. Fruit: very large (to medium in later part of season); oblate; light blue; scar small; excellent firmness and flavor; requires cross-pollination; ripens early-season, similar to Spartan; good postharvest shelf life; suitable for fresh market. Plant: moderately vigorous; upright; height $120-150 \mathrm{~cm}$; flowers similar to Spartan; moderate productivity; wider soil adaptability than Spartan.

Ventura. Early-season southern highbush blueberry for handharvest fresh markets. Origin: Fall Creek Farm and Nursery Lowell, OR, by D. Brazelton and A. Wagner. FL00-60 × FL96-24; crossed 2000 by Florida Foundation Seed Producers, Inc.; selected 2006; tested as FF-89; introduced 2011; US Patent Application US 2013/ 0239023 P1. Fruit: medium; medium blue; semi-spherical shape with a slight taper towards the calyx; small, dry scar; sweet flavor without strong acid component. Plant: extremely vigorous upright growth habit; fruit releases easily; good machine harvest potential; suitable for use in evergreen management systems in areas with very little chill.

\section{Vireo $^{\mathrm{TM}}$. See FL05-107.}

ZF05-196 (Jam Session). Mid-season, high-chill blueberry for the home gardener. Origin: Fall Creek Farm and Nursery, Lowell, OR, by D. Brazelton and A. Wagner. Duke $\times$ Legacy; crossed 2002 in Lowell, OR; selected 2005; tested as ZF05-196; introduced 2013; Patent Application US 2013/0239259 P1. Fruit: medium; long, attractive clusters; medium blue; medium firmness; round; sweet; slight flavor of grapes. Plant: upright; vigorous with very high yields.

ZF06-043 (Peach Sorbet). Ornamental blueberry for nursery, landscape, and home garden use. Origin: Fall Creek Farm and Nursery, Lowell, OR, by D. Brazelton and A. Wagner. FLX-2 (Bountiful Blue; FL95-12) $\times$ Toro; crossed 2003; selected 2006; tested as ZF06-043; introduced 2011; USPP 23,325 P2. Fruit: medium; small, dry scar; mildly sweet; moderately firm; smooth texture. Plant: medium; round, compact growth habit; deep green foliage with pink and orange new growth, which turns a deep purple color in the fall; retains foliage throughout the winter in Lowell, OR; self-fertile.

ZF06-079 (Pink Icing). Ornamental blueberry for nursery, landscape, and home garden use. Origin: Fall Creek Farm and Nursery, Lowell, OR, by D. Brazelton and A. Wagner. Toro $\times$ FLX-2 (Bountiful Blue; FL95-12); crossed 2003; selected 2006; tested as ZF06-079; introduced 2011; USPP 23,336 P2. Fruit: medium; round; medium dry scar; medium firmness; mildly sweet; smooth texture. Plant: medium; striking blue-green foliage with pink new growth throughout spring and summer; attractive lavender color in the fall; compact growth habit; self-fertile.

ZF06-179 (Jelly Bean). Cold-hardy ornamental blueberry for nursery, landscape, and home garden use. Origin: Fall Creek Farm and Nursery, Lowell, OR, by D. Brazelton and A. Wagner. Polaris $\times$ Tophat; crossed 2003; selected 2006; tested as ZF06-179; introduced 2011; Patent Application US 2013/0239263 P1. Fruit: medium; juicy berry with a balance between sweet and tart; smooth texture. Plant: dwarf growth habit; light green foliage with red tips throughout the growing season, turning yellow and red in the fall; self-fertile.

ZF06-288 (Last Call). High-yielding very-late-season northern highbush blueberry for the fresh market. Origin: Fall Creek Farm and Nursery, Lowell, OR by D. Brazelton and A. Wagner. Elliott $x$ Ozarkblue; crossed 2002; selected 2006; tested as ZF06-288; introduced 2012; USPP applied for. Fruit: large; light blue; slightly flattened; firm flesh with aromatic flavor; ripens with Aurora and Elliott. Plant: excellent vigor; upright growth; thick diameter canes.

ZF08-095 (Blueberry Glaze). Ornamental blueberry for nursery, landscape, and home garden use. Origin: Fall Creek Farm and Nursery, Lowell, OR, by D. Brazelton and A. Wagner, A. Draper. JU-60 × US-702; crossed 1988 (Beltsville, MD); selected 2008; tested as ZF08-095; introduced 2011; US Patent Application US 2013/0298296 P1. Fruit: small; round; dark-colored; sweet and aromatic flavor. Plant: semi-dwarf plant with mounded growing habit; dark green, shiny foliage with reddish new growth, turning yellow and red in the fall, semi-evergreen.

\section{CITRUS}

Ed W. Stover, USDA-ARS US Horticultural Research Laboratory, Ft. Pierce, FL

Tracy Kahn, Mikeal Roose, Toni Siebert, and Georgios Vidalakis, University of California, Riverside, CA

Robert Krueger, USDA-ARS National Clonal Germplasm Repository for Citrus and Dates, Riverside, CA

Fred Gmitter and Jude Grosser, Citrus Research and Education Center, University of Florida, Lake Alfred, FL

914 (UF 914). Red-flesh, seedless pummelo-grapefruit triploid hybrid with very low furanocoumarin content, potentially avoiding the socalled "grapefruit juice effect." Origin: University of FloridaInstitute of Food and Agricultural Sciences-Citrus Research and Education Center, Lake Alfred, FL by F.G. Gmitter, Jr., J.W. Grosser, and W.S. Castle. Siamese Sweet (CRC 2240, PI 539355, low acid pummelo) $\times$ Ruby Red grapefruit (tetraploid from undeveloped ovules from a chimeric, deep red sector of a Ruby Red through in vitro embryogenesis); crossed 2002; original seedling topworked onto a branch of a mature tree in 2004; selected 2008; introd. 2013 (USPP pending). Fruit: grapefruit shape, larger in size (average weight $680 \mathrm{~g}$ ) and with a thicker peel than typical grapefruit; typical grapefruit appearance with yellow rind and red blush; uniform red flesh color and seedless; ripens beginning of October in central Florida, can remain on the tree until March-April, depending on season; typical grapefruit flavor and aroma, perceived as sweeter because of higher Brix (10 ${ }^{\circ}$ Brix) and Brix/acid ratio (7.6), and lower acidity (0.99-1.21); very low content of furanocoumarin compounds. Tree: structure and leaf characteristics similar to grapefruit, leaves more closely resemble the pummelo parent foliage type; slightly thicker and broader leaf blades, and more conspicuous venation, typical of polyploid citrus plants; fruiting regular and annual.

950 (UF 950). Nearly seedless midseason mandarin for the fresh fruit market. Origin: University of Florida-Institute of Food and 
Agricultural Sciences-Citrus Research and Education Center, Lake Alfred, FL by F.G. Gmitter, Jr., J.W. Grosser, and W.S. Castle. LB8-8 [acidless fruited hybrid of Clementine mandarin $\times$ Minneola tangelo (Dancy tangerine $\times$ Duncan grapefruit) $] \times$ Fortune mandarin (Clementine mandarin $\times$ Dancy tangerine); crossed 1991; planted 1993 and transplanted 2000; selected 2007; introd. 2013. USPP 23,359; 29 Jan. 2013. Fruit: small-medium, round $(55-70 \mathrm{~mm}$ diameter, and 55-60 $\mathrm{mm}$ tall); orange to orange-red rind; very easy to peel and to separate the segments without expressing juice; flesh orange; sweet with excellent flavor and aroma $\left(13.10^{\circ}\right.$ Brix, $0.82 \mathrm{~g} \cdot \mathrm{L}^{-1}$ citric acid, and $15.98 \mathrm{Brix} /$ acid in late December); ripens in early to mid-December in most seasons in central Florida, and can be harvested until mid-January in some seasons. Tree: typical mandarin vigor and structure; flowers well annually; fruit set can be light but is substantially increased by applications of gibberellic acid or by light girdling of the trunk or major scaffold branches at bloom time and shortly thereafter; fruit and foliage very tolerant to Alternaria brown spot (Alternaria alternata).

Australian Finger Lime (VI 697). Specialty fruit, citrus relative also known as Microcitrus australasica one of six different species of citrus considered to be native to Australia. Origin: imported from Sydney, Australia, in 1965, released by Citrus Clonal Protection Program (CCPP) as VI 697 in 2007. Fruit: about 3 inches long and roughly the size of an average person's index finger, but fruit from juvenile trees can be less than 1 inch long; greenish black to very dark purple, thin durable skin; flesh clear-green to very light pink tiny round juice vesicles, resemble "citrus caviar"; very tart juice, much like a Mexican lime; main ripening season in California is NovemberDecember when the fruit falls off in your hand. Tree: very small (about $5 \mathrm{ft}$ on Schaub rough lemon) to large depending on the rootstock (the CVC has used several: Schaub rough lemon, Cleopatra mandarin, C-35 citrange, Carrizo citrange, Calamondin, Citrus macrophylla); leaves are tiny approximately one-half inch long and the branches become very dense and thorny with about one thorn set in every leaf axil; new growth is purple in color and the one-quarter inch wide flowers are white and pink during the main flowering season of February to April.

Avana apireno (VI 688). Willowleaf-type mandarin. Origin: originating in Sicily, Italy either in the 1800's or in 1962 (ambiguous passport data), The Instituto Sperimentale per l'Agrumicoltura, Acireale, in Sicily, Italy, donated budwood to INRA, San Giuliano, Corsica, France, in 1983; received by the Citrus Clonal Protection Program (CCPP) in 1997, released as VI 688 in 2010. Fruit: flattened shape like Avana tardivo (average length/width ratio of 0.82 ); pale orange rind; flesh medium orange; average 3.1 seeds per fruit; ripens by early December in Lindcove, Exeter, CA. Tree: vigorous $(5.0 \mathrm{ft}$ in height with a 5 - $\mathrm{ft}$ diameter, 4-year-old trees at Riverside, CA) dense and spreading.

Avana tardivo di Ciacalli (VI 687). Late maturing, willowleaf type mandarin, in US commonly known as Mediterranean mandarin. Origin: Ciaculli, Sicily, Italy, ; donated to INRA, San Giuliano, Corsica, France, in 1966; received by the Citrus Clonal Protection Program (CCPP) in 1997; released as VI 687 in 2010. Fruit: flattened (average length/width ratio of 0.83 ); pale orange rind; flesh medium orange; average 8.3 seeds per fruit; ripens in early January (a month later than 'Avana apireno') in in Lindcove, Exeter, CA; taste is best in February. Tree: vigorous ( $5.5 \mathrm{ft}$ in height with a 5 - $\mathrm{ft}$ diameter, 3 -yearold trees in Riverside, CA) and spreading.

Bahianinha (VI 699). Navel orange. Origin: Piracicaba, Sao Paulo, Brazil; donated to INRA, San Giuliano, Corsica, France, in 1971; received by the Citrus Clonal Protection Program (CCPP) in 1997 and released as VI 699 in 2010 . Fruit: smaller, more oval-shaped with a smaller, closed navel and a thinner rind tha Parent Washington; good fruit quality when grown on an appropriate rootstock; ripens 1-2 weeks earlier than Parent Washington. Tree: productive, smaller and less vigorous than Parent Washington.
Bahianinha Araras (VI 700). Navel orange better adapted to hot, tropical climates than Parent Washington. Origin: Instituto Agronomico do Estado Sao Paulo Campinas, Sao Paulo, Brazil; received by the USDA-ARS Horticultural Research Station in Ft. Pierce, FL, in 1940, and obtained by the Citrus Clonal Protection Program (CCPP) in 1999. Fruit: smaller, more oval-shaped with a smaller, closed navel and a thinner rind; good fruit quality when grown on an appropriate rootstock; ripens 1-2 weeks earlier than Parent Washington Naval Orange. Tree: productive, smaller and less vigorous than Parent Washington; less prone to alternate bearing than Parent Washington with differences less pronounced in California than in Brazil.

Bouquetier de Nice (VI 720). Specialty fruit, chosen for introduction to US due to the attractive horned fruits observed in Corsica. The Bouquetier-type sour oranges represent a distinctive group of bigarade-type sour or bitter oranges primarily grown for their perfumed flowers used in production of high quality neroli oil and its byproduct of orange flower water. Origin: Pamplona, Navarre, Spain, around 1421; obtained by the Institut Francais Recherches Fruitieres Outre-mer, Rabat, Morocco, and introduced into the Germplasm Agrumes Collection at Station de Recherches Agronomiques, Corsica, France, in 1960; obtained by the Citrus Clonal Protection Program (CCPP) in 1997 and released as VI 720 in 2011. Fruit: flattened fruit; most of the fruits on the trees in Riverside, CA did not have the horns; all of the fruits that were cut open showed the secondary fruit. Tree: small with few thorns and many flowers; leaves large, broad, and slightly tapered.

C4-15-19. Early-maturing seedless mandarin for fresh market. Origin: University of Florida-Institute of Food and Agricultural Sciences-Citrus Research and Education Center, Lake Alfred, FL by J.W. Grosser, F.G. Gmitter, Jr. and W.S. Castle. LB8-9 (USPP 21,356), diploid monoembryonic mandarin hybrid (female parent) $\times$ Nova mandarin, allotetraploid somatic hybrid (Clementine x Orlando) + Succari sweet orange (Citrus sinensis L. Osbeck) (male parent); obtained via embryo rescue, planted 2005; selected 2010; introd. 2013. Fruit: small-medium; seedless; easy to peel; dark orange rind with pronounced oil glands, pleasant fragrance when peeled; ripens in October-November in central Florida with exceptional sweet flavor. Tree: upright and lateral growth with drooping branches during heavy cropping.

California Roja (VI 760). Pigmented navel orange. Origin: Presumably a mutation of a standard navel orange; donated to the Germplasm Agrumes Collection at Station de Recherches Agronomiques, Corsica, France, in 1984; donated to the Citrus Clonal Protection Program (CCPP) in 1997; released by CCPP as VI 760 in 2010. Fruit: may be the same as Cara Cara. In Corsica, Cara Cara navel and California Roja navel are not at the same location, and sometimes there are differences in ripening time or coloration, but globally they really look the same. 'California Roja' was introduced to Corsica from Venezuela in 1984 and Cara Cara was introduced from Spain in 1991. Tree: Similar to most other navel trees.

China S-9 (VI 636). Satsuma mandarin selected from fields devastated after a very bad freeze and rated for cold hardiness, fruit quality, and tree vigor. Origin: collected in the Hubei, Sichuan, and Hunan Provinces of China, by Dr. H. Huang, Auburn University, AL, in June 1995 and Oct. 1998; released by Citrus Clonal Protection Program (CCPP) as VI 636 in 2007. Fruit: larger than most other satsumas; doesn't reach color break as soon as some of the early satsumas; ripes early in Riverside and the San Joaquin Valley, CA (about the same time as Miyagawa and Xie Shan). Tree: typical of satsuma trees.

Early St. Ann (VI 825). Tender, melting, easy peeling seedless satsuma mandarin. Origin: O.P. seedling planted at Louisiana State University Citrus Research Station in Port Sulphur by R. Brown, first superintendent of the station, in the late 1960s; selected in 1980s; sent to Citrus Clonal Protection Program (CCPP) for sanitizing in 
2007; released by CCPP as VI 825 in 2012. Fruit: typical satsuma fruits, medium to large; oblate; light yellow, thin leathery skin with an attractive appearance; peel adherence slight to moderate, easy peeling, common to satsuma mandarins; fruit puffiness ranges from none to slight; flesh orange, more intense than Early Armstrong; tender and melting, with easily separating segments; considered seedless, but it may have an occasional seed. Tree: medium and very productive; spreading with drooping thornless branches; leaves dark green, large (3-4 inches long and 1-3 inches wide), lanceolate, tapering at base and apex with a thin petiole.

FairchildLS. Mid-season, low-seeded mandarin. Origin: University of California, Riverside by T.E. Williams and M.L. Roose Gamma irradiation of buds of Fairchild, selected 2002, tested as Fairchild IR2, introd. 2010; USPP 22,649 P3. Fruit: medium, deep oblate to oval, no neck; rind moderately smooth, orange, moderately thin $(3.5 \mathrm{~mm})$, moderately easy to peel, seed per fruit about 2.4 , rarely up to 7-8; flesh moderately fine texture and orange color, juicy, flavor rich and sweet at maturity, ripens November to January. Tree: compact, rounded growth habit, thornless, yield high with cross pollination, medium alternate bearing, pollen viability low, $25-35 \%$ and pollen quantity is about $20 \%$ that of Fairchild.

Fukushu (VI 805). Small, thornless kumquat. Origin: probably originating in China, the bud source for this kumquat was obtained from Willits \& Newcomb Citrus Nursery, Arvin, CA; released by Citrus Clonal Protection Program as VI 805 in 2012. Fruit: medium, broadly obovate with a markedly depressed apex, thin rind; large number of segments (five or six, sometimes as many as eight); seeds few and polyembryonic. Tree: small and thornless.

Hansen (VI 709). Mandarin selection released by as VI 709 in 2010. Origin: most probably a tangor arose as an O.P. chance seedling in South Australia, originated on the property of Mr. Hansen of Renmark, South Australia; introduced as seed by the Germplasm Agrumes Collection at Station de Recherches Agronomiques, Corsica, France; and obtained as budwood by the Citrus Clonal Protection Program (CCPP) in 1997; released by CCPP as VI 709 in 2010. Fruit: medium; oblate; yellowish-orange, thin rind; flesh orange, moderately juicy; seedy (up to 12 seeds per fruit); moderate quality with good sugars but high acid levels that remain high until late in the season, giving good flavor from February to March; begins to reach color break in mid-November, but does not reach legal maturity until early January at Lindcove, Exeter, CA; Tree: strong vigor ( $6 \mathrm{ft}$ tall and $5 \mathrm{ft}$ in diameter ), and spreading growth habit.

Hickson (VI 685). Mid season mandarin. Origin: near the town of Roma, Queensland, Australia, as a sporting limb on Ellendale tangor; released by Citrus Clonal Protection Program as VI 685 in 2008. Fruit: similar in appearance to its Ellendale progenitor but the rind is not as smooth; peels more easily; averages $6 \mathrm{~cm} \times 5 \mathrm{~cm}$, has a slight neck, and a smooth, yellowish-orange rind with some gloss; flesh orange and juicy; good flavor; seeded with 12-15 seeds; in Australia, a mid-season variety, ripens in late June, about 2 weeks earlier than Ellendale; considered to hang better than Ellendale, with the harvest date extending through August. Tree: similar to Ellendale.

Imperial (VI 684). Early maturing mandarin. Origin: chance hybrid of Mediterranean or Willowleaf and another mandarin, possibly Emperor in approximately 1890 in Emu Plains, near Sydney, Australia; released by Citrus Clonal Protection Program as VI 684 in 2008. Fruit: medium or small in heavy crop years; yellow orange rind, more intense in regions with cool fall temperatures; generally must be clipped from the tree rather than plucked; skin is thin and soft, and although adherent, peels easily; firm when peeled; good quality; good balance of sugar and acid and good internal color; juice levels at least $35 \%$; granulation sometimes a problem because of the low juice content; usually 4 or fewer seeds per fruit in both solid and mixed plantings; short post-harvest life, 2-4 weeks; de-greening necessary when fruit are harvested early; Brix:acid ratio reaches
7:1 around mid-March in the earliest regions of Australia, with later regions reaching this ratio in early June; ripens extremely early, equivalent to Owari satsuma; can be harvested up to July or August in Australia, depending upon the region. Tree: vigorous and upright.

KinnowLS. Late-season low-seeded mandarin. Origin: University of California, Riverside by T.E. Williams and M.L. Roose. Gamma irradiation of buds of Kinnow, selected 2003, tested as Kinnow IR5, introd. 2011; USPP 23,743 P3. Fruit: medium, oblate, no neck; rind very smooth, orange, thin and generally easy to peel; seed per fruit about 2.5 , rarely up to 7 ; flesh moderately fine texture and orange color, flavor very sweet (SS 13-17\% in March); ripens December to March, holds well on tree. Tree: vigorous with vertical growth habit; thornless; yield high but prone to alternate bearing; pollen viability low, $10-20 \%$.

Lemonade (VI 734). Specialty fruit, semi-dwarfed lemon hybrid. Origin: sweet lemon hybrid of unknown parentage originating in New Zealand; bud source obtained from Nuccio's Nursery in Pasadena, CA; released by Citrus Clonal Protection Program (CCPP) as VI 734 in 2008. Fruit: small-medium; not very seedy; very pleasant taste; readily but not easily peeled; ripens in early spring in New Zealand, with much smaller summer crops. Tree: semidwarfed (on trifoliate rootstock), quite productive; tested negative for all known graft-transmissible diseases, trees propagated in Riverside, CA have shown a tendency to develop small brown to black lesions of unknown cause on the bark; trees propagated at Riverside are not particularly vigorous.

Marumi (VI 673). Golden yellow kumquat. Origin: received by the Germplasm Agrumes Collection at Station de Recherches Agronomiques, Corsica, France, in 1966 from Willits and Newcomb in Arvin, California; budwood received by the Citrus Clonal Protection Program from INRA, San Giuliano, Corsica, France, in 1997; released by Citrus Clonal Protection Program as VI 673 in 2010. Fruit: spherical or somewhat oblate, 1 to $1-1 / 4$ inches $(2.5-3 \mathrm{~cm})$ in diameter; golden yellow, short stalked; calyx small; rind smooth, thin, spicy to the taste and aromatic when bruised; oil cells large; pulp sparse; juice acid; sections four to seven; seeds one to three, small, oval, greenish; cotyledons two, greenish; ripening season same as Nagami (matures in the winter and holds well on the tree). Tree: similar to Nagami ( $F$. margarita), except that it is slightly thorny, and has the leaves somewhat smaller and rounder at the apex; leaves oval; apex obtuse; margin crenate halfway down the length; veins slightly more conspicuous than in Nagami; borne on short rigid, inconspicuously winged petioles, $1 / 4$ to $1 / 2$ inch $(6-13 \mathrm{~mm})$ long.

Miyamoto (VI 779). Satsuma mandarin Origin: budsport discovered on the property of L. Miyamoto, in Wakayama, Japan; donated to the Fruit Tree Research Station in Okitsu, Shizuoka, Japan; budwood sent to the Instituto Valenciano de Investigaciones Agrarias in Valencia, Spain, in 1988 and donated to the Citrus Clonal Protection Program (CCPP) in 2007; released by CCPP as VI 779 in 2010. Fruit: medium; more spherical than Okitsu or Miyagawa; good color, particularly the flesh, and a high Brix level; ripens 10 days and 15 to 20 days earlier than Okitsu and Miyagawa, respectively. Tree: typical satsuma tree.

OLL - 8. Late maturing sweet orange for fresh market or processing. Origin: University of Florida-Institute of Food and Agricultural Sciences-Citrus Research and Education Center, Lake Alfred, FL by J.W. Grosser, F.G. Gmitter, Jr. and W.S. Castle. Somaclone of OLL (Orie Lee Late) sweet orange, plant regenerated from embryogenic callus culture, planted 2004; selected 2010, introd. 2013. Fruit: round; exceptional juice quality and flavor;juice color usually exceeds that of Rhode Red Valencia; ripens in March in central Florida, but can hold on the tree into June. Tree: typical sweet orange tree with good vigor; apparently better stress tolerance than Valencia. 
Primosole (VI 777). Early ripening mandarin hybrid. Origin: University of Catania, Sicily, in 1980; Carvalhais mandarin $\times$ Miho Wase satsuma; released by Citrus Clonal Protection Program as VI 777 in 2009. Fruit: large, $150 \mathrm{~g}$ in southern Italy; oblate; orange rind; peel separates easily; flavor between satsuma and mandarin; handles degreening well; stores well; handles cold sterilization well; firm rind in comparison to satsumas; tends to have a ricyness in the core of the fruit that lessens with tree age; was completely granulated by the first sample dates in late September for the past 3 years in Lindcove Research and Extension Center, Exeter, CA; selfincompatible, but will pollinize compatible cultivars such as clementines; seedless in isolation and ripens very early (at the beginning of October in southern Italy or early April in Australia); Tree: thornless branches; lanceolate leaves that tend to fold as if under water stress; very sensitive to strong winds and can defoliate under windy conditions; good to very good crop load.

Rubidoux \#1 (VI 570) and Rubidoux \#2 (VI 571). Grapefruit hybrids. Origin: USDA Date and Citrus Station, Indio, released to UCR when the Station closed; left in the Citrus Clonal Protection Program (CCPP) Rubidoux screen house when E. Nauer retired in 1990; released by Citrus Clonal Protection Program as VI 570 and 571 in 2010. Grapefruit-pummelo hybrids of unknown parentage (indexed by D. Gumpf). Fruit: flesh light pink to pink; tender; juicy, with a very fine texture; flavor is sweet with very low bitterness and low acidity, similar to Oroblanco; thick pummelo-like rind; fairly seedy; both types have been sampled in Riverside, CA from January through June, when they are very sweet; VI 571 tends to be the sweeter of the two with a darker yellow rind and continues to be favored above VI 570. Tree: moderate size, vigor.

Santa Teresa (VI 835). Lemon selection Origin: Italian selection of the Femminello Ovale type, considered to have greater resistance to the mal secco disease than other clones. The parent tree in Italy was an old disease-free tree discovered in a Femminello orchard that had almost been destroyed by the disease; released by Citrus Clonal Protection Program as VI 835 in 2012. The current bud source, sanitized at CCPP, was obtained from Willits \& Newcomb Citrus Nursery, Arvin, CA; it is quite old, being obtained by Albert Newcomb, and it may or may not have the same origin as the Santa Teresa selection established at Riverside as CRC 3894 (PI 227692) in 1959. We can find no documentation of 'Santa Teresa' introductions other than PI 227692 and it is assumed that PI 227692 and VI 835 have similar characteristics. Fruit: elliptical to oblong, with a slightly necked to rounded base and a short, blunt nipple; 2.50 to 2.75 inches in diameter equates to a 75 to 95 box count; yellow peel at full maturity; moderately smooth texture; medium thickness and high oil content; the greenish-yellow flesh is tender, juicy and highly acidic; few seeds to seedless. Tree: round in shape; moderately vigorous, upright and spreading, with branches that are nearly thornless; medium height; highly productive, setting flowers and fruit throughout the year.

SPB-7. Reputedly wood pocket-free selection of Persian lime. Origin: Wood pocket was formerly very common in Florida and caused extensive losses. The industry requested help from researchers and after screening more than 100,000 trees, 10 trees were identified that were apparently free of wood pocket, based upon their survival. The current selection (SPB-7) was entered into the program in 1954 as Li-38-1-1-X. This selection was apparently erroneously identified as being wood pocket positive and was dropped but later reinstated and never showed wood pocket symptoms. The current selection was entered into the Florida Department of Plant Industries foundation program about 1961 and was imported into California in 2000; released by Citrus Clonal Protection Program as VI 708 in 2007. Fruit: typical of Persian type limes (large, acid limes). Tree: Trees of this selection have been planted at various places in California for evaluation as to the development of wood pocket. One of these locations is the Coachella Valley Agricultural Research Station in Thermal, CA. Since wood pocket develops more rapidly at high temperatures, the trees in Thermal should be the most susceptible to development of wood pocket. At this time, no wood pocket symptoms have been observed in Thermal. However, a personal communication from Costa Rica has indicated that under those conditions, wood pocket did appear. It is not clear as to why performance is different in California, Costa Rica, and Florida.

Sudachi (VI 693). Specialty fruit, used for cooking, and food and beverage flavoring while green. Origin: Tokushima Prefecture of Japan, on Shikoku island; chance seedling of papeda $\times$ mandarin hybrid; released by Citrus Clonal Protection Program as VI 693 in 2007. Fruit: oblate to round; significantly smaller than Yuzu, (27.2 g; $3.8 \mathrm{~cm}$ width and $3.4 \mathrm{~cm}$ length); color break between the first and third week of September; rind texture slightly pebbly, $1.9 \mathrm{~mm}$ thick; internal flesh color in the green stage is light green to green-yellow; mean juice weight $9.6 \mathrm{~g}$ and juice content $34.4 \%$; juice weight and juice content increased during the sampling dates; slightly more acidic than Yuzu with an average of 5\% citric acid; seed per fruit 9; when harvested young is considered to have a distinctive fragrance that is different from Yuzu; young fruits are used for cooking while still green, often being incorporated into vinegars or flavoring many different entrees, especially fish; flavor is now also used in soft drinks and alcoholic beverages. Tree: small to medium, moderate vigor; spreading (26-years-old trees on Carrizo and C-35 citrange rootstocks approximately $8 \mathrm{ft}$ tall, with no indications of rootstock-scion incompatibility); dense branching; leaves elliptical, with a small winged petiole; thorns up to $5 \mathrm{~mm}$ long in each leaf axil;the canopy has dense branching.

UF 914. See 914.

\section{UF 950. See 950.}

US Furr. Mid-season mandarin. Origin: USDA/ARS, at the US Horticultural Research Laboratory in Orlando, FL in 1953, Clementine $\times$ Murcott by P. Reece; selected by J. Furr at the USDA/ARS Indio, CA Date and Citrus Station in 1962; officially released 2014; widely tested under names C-54-4-4, Diamantina, Murcotão, Olé, Piemonte, SRA 337, and Taylor-Lee. Fruit: medium, oblate, no neck, flattened at apex; rind lightly pebbled, orange to scarlet/orange, generally easy to peel; seed per fruit 12-24 in mixed plantings; flesh moderately fine texture, deep orange in color, rich and sweet in flavor (SS 10.5-12.1\%); ripens December to January. Tree: spreading; thornless; yield similar to Murcott; susceptible to citrus scab.

US Furr-ST. Mid-season, scab tolerant mandarin. Origin: USDA/ ARS at the US Horticultural Research Laboratory in Orlando, FL in 1953, Clementine $\times$ Murcott by P. Reece; selected by J. Furr at the USDA/ARS Indio, CA Date and Citrus Station in 1962; irradiated in 1975 and again in 1990 by $\mathrm{H}$. Wutscher and a scab tolerant variant identified; officially released 2014; tested under names Clemcott, Furr and Clementine $\times$ Murcott. Fruit: medium, oblate, no neck, flattened at apex; rind lightly pebbled, orange to scarlet/orange, generally easy to peel; seed per fruit 12-24 in mixed plantings; flesh moderately fine texture, deep orange in color, and rich and sweet in flavor (SS 13.0-13.6\%); ripens December to January. Tree: spreading growth habit; thornless; yield similar to Murcott; reduced susceptibility to citrus scab compared to US Furr.

Verna (VI 701). Lemon selection Origin: Instituto Valenciano de Investigaciones Agrarias in Valencia, Spain, a Spanish cultivar of unknown origin, possibly arising in Murcia, Spain, from Monachello lemon; received by Citrus Clonal Protection Program (CCPP) in 2002; released by CCPP as VI 701 in 2010. Fruit: medium to large; oval to broad-elliptical; neck or collar short; nipple well developed; bright yellow at maturity; peel medium-thick (thinner in summer crop); surface somewhat pebbled, rough; tightly adherent; seed per fruit variable, but usually few to none; high juice content but with 
lower acids than other lemons; ripens mainly in winter but holds well into summer. Tree: very vigorous, upright-spreading, large, and productive, usually flowers twice, with most fruit held inside the tree.

VI 570. See Rubidoux \#1.

VI 571. See Rubidoux \#2.

VI 621. See Xie Shan.

VI 636. See China S-9.

VI 673. See Marumi.

VI 684. See Imperial.

VI 685. See Hickson.

VI 687. See Avana tardivo di Ciacalli.

VI 688. See Avana apireno.

VI 693. See Sudachi.

VI 697. See Australian FingerLime.

VI 699. See Bahianinha.

VI 700. See Bahianinha Araras.

VI 701. See Verna.

VI 709. See Hansen.

VI 720. See Bouquetier de Nice.

VI 734. See Lemonade.

VI 760. See California Roja.

VI 777. See Primosole.

VI 779. See Miyamoto.

VI 805. See Fukushu.

VI 825. See Early St. Ann

VI 835. See Santa Teresa.

Xie Shan (VI 621). Early satsuma mandarin. Origin: Institute of Subtropical Crops of Zheijiang Academy in China in 1992, collected by F. Gmitter, University of Florida, released by Citrus Clonal Protection Program as VI 621 in 2007. 'Xie Shan' is the Chinese translation that originally came from Japan where it was named Wakiyama. Fruit: In China, "extremely early ripening in comparison to other Chinese satsumas"; in a California trial, developed high brix levels somewhat earlier than other early satsuma cultivars tested (e.g., Armstrong, Miyagawa, and Chinese S-9); however, high acid levels kept the sugar/acid ratio within about the same range as the other cultivars. Xie Shan and Miyagawa were considered the earliest cultivars in this trial. Additionally, it was reported that 'Xie Shan' was completely seedless, easy peeling, and had a unique taste and flavor; projected harvest in the San Joaquin Valley, CA was midSeptember. Tree: typical of satsuma trees.

\section{CITRUS ROOTSTOCK}

Ed Stover, USDA-ARS US Horticultural Research Laboratory, Ft. Pierce, FL

Tracy Kahn, Mikeal Roose, Toni Siebert and Georgios Vidalakis, University of California, Riverside, CA

Robert Krueger, USDA-ARS National Clonal Germplasm Repository for Citrus and Dates, Riverside, CA

Fred Gmitter and Jude Grosser, Citrus Research and Education Center, University of Florida, Lake Alfred, FL

Sunki (VI 806). Traditional citrus rootstock. Origin: South China; came to the U.S. in 1956 from the Tanaka Institute of Citriculture and Horticultural Science in Japan; released by Citrus Clonal Protection Program as VI 806 in 2012. Plant: medium-small, upright tree with distinctive pale green leaves; a sour mandarin; medium-small fruit, markedly depressed at both ends; very thin rind, loose; light yellowish-orange, with a smooth, shiny surface and prominent oil glands; flavor acid; fruit not edible; seeds are medium-large, plump, and polyembryonic. Use: widely used as a rootstock in China but has not had extensive evaluation in other areas; tolerant of tristeza and xyloporosis but susceptible to exocortis; susceptible to Phytophthora but has survived well in some trials; tolerant of blight-like diseases in Brazil. Trees propagated on Sunki are reported to be highly salt tolerant, moderately cold hardy, and only slightly susceptible to chlorosis on calcareous soils; smaller than standard in China and Texas but large in Florida and California;fruit yield and quality equivalent to trees on sour orange or Cleopatra mandarin. Sunki is polyembryonic but has a higher proportion of zygotic seedlings than many other rootstocks.

\section{CRANBERRY}

Nicholi Vorsa, Department of Plant Biology and Pathology, Rutgers University, New Brunswick, NJ

Sundance. See WI-92-A-x15.

WI-92-A-X15 (Sundance). Mid- to late season cranberry with large berries, high yields, high fertilizer tolerance and excellent flower bud formation. Origin: University of Wisconsin-Madison, Madison, WI, by E.L. Zeldin and B.H. McCown. Stevens x BL8 (O.P. Ben Lear seedling); crossed 1990; selected 1992; introd. 2010; USPP applied for. Fruit: early-bulking, large, typically 2.25 to 2.75 g; oblongelliptical shape; mid- to late season maturity; anthocyanin content reliably over $40 \mathrm{mg} / 100 \mathrm{~g}$ fruit in early to mid-October, significantly higher fruit color development than Stevens in WI. Plant: very vigorous vine during establishment; once established, little vegetative growth, with a high tolerance to nitrogen fertilizers compared to other cranberry cultivars; exceptional recovery after mowing. Bud set: high flower bud set on fruiting and non-fruiting stems, uniform annual flowering and high yields. Extremely high floral bud set on mowed plantings.

\section{CURRANT}

\section{Kim E. Hummer, USDA ARS National Clonal Germplasm Repository, Corvallis, OR}

Ben Chaska. Early ripening, cold hardy, large fruited, rust resistant, black currant for mechanical harvest. Origin: James Hutton Institute, Invergowrie, Great Britain, by R.M. Brennan. SCRI P10/9/20 x Polar; crossed 1984; selected 1986; tested as SCRI D16/6/54; introd. 2013; USPP 23,417; 26 Feb. 2013. Fruit: large; black; round; early ripening, before Ben Como; flavor sweet-acid; fruit set $1.6 \mathrm{~kg}$ per plant in Becker, $\mathrm{MN}$; recommended for machine harvesting for processing. Plant: cold hardy; consistent cropping levels; compact; upright; resistant to white pine blister rust caused by Cronartium 
ribicola J.C. Fischer; resistant to powdery mildew caused by Sphaerotheca mors-uvae (Schwein.) Berk. et Curtis.

Ben Como. High yielding, cold hardy, rust resistant, black currant for mechanical harvest. Origin: James Hutton Institute, Invergowrie, Great Britain, by R.M. Brennan. SCRI P10/9/20 x Ri-74020-16; crossed 1984; selected 1986; tested as SCRI D16/8/14; introd. 2013; USPP 23,416; 26 Feb. 2013. Fruit: medium-size, black; round; midseason ripening, after Ben Chaska; flavor sweet-tart; high fruit set; $2.7 \mathrm{~kg}$ per plant in Becker, MN; recommended for machine harvesting for processing. Plant: later blooming, more vigorous, and larger plant than Ben Chaska; cold hardy; upright; resistant to white pine blister rust caused by Cronartium ribicola J. C. Fischer; resistant to powdery mildew caused by Sphaerotheca mors-uvae (Schwein.) Berk. et Curtis.

\section{ELDERBERRY}

Patrick L. Byers, Greene County Extension Office, University of Missouri Extension, Springfield, MO

Marge. Consistent yielding European elderberry adapted to the midwestern U.S. Origin: University of Missouri/Missouri State University, by A.L. Thomas and P.L. Byers. O.P. seedling of Haschberg, selected by Margaret Millican in 2007; introd. 2013. Fruit: large, $176 \mathrm{mg}$; skin dark; high quality; juice sdoluble solids $10.2^{\circ}$ Brix, $\mathrm{pH}$ 5.7. Cyme: small, $15 \mathrm{~g}$; ripens uniformly; resistant to shattering; decumbent position when ripe; abundant florets that are easily removed for use. Plant: medium, 1.5-2.2 m; upright; budbreak later, bloom time earlier than American elderberry cultivars; same harvest time as Bob Gordon; higher yields than American elderberry in several trials; consistent production. Less incidence of eriophyid mite damage than American elderberry in several trials.

\section{GRAPE}

\section{Christopher L. Owens, USDA-ARS, Grape Genetics Research Unit, Geneva, NY}

A-1710 (Tickled Pink ${ }^{\mathrm{TM}}$ ). Red, seedless, fresh-market table grape for the home garden. Origin: University of Arkansas Division of Agriculture, Fayetteville, AR, By J.R. Clark and J.N. Moore. Moored $\times$ NY 45791; tested as Ark. 1710; crossed 1976; selected 1979; introd. 2011. USPP applied for. Fruit: red; round; seedless with very small seed traces; slipskin; medium skin; resists cracking; very strong foxy flavor; soluble solids $22{ }^{\circ}$ Brix; ripens very early, mid-July in Arkansas. Cluster: small, 125 g; short cylindrical; well-filled. Vine: moderate vigor; hardy to $-15^{\circ} \mathrm{C}$ to likely colder; lobed leaves, unusual for a Vitis labrusca-type vine.

Arandell. Disease-resistant red wine grape. Origin: Cornell University, Geneva, NY, by B.I. Reisch, R.S. Luce, J.E. Vanden Heuvel and A.K. Mansfield. NY84.0101.03 × NY88.0514.01; tested as NY95.0301.01; crossed 1995; selected 2001; introd. 2013. Fruit: black; small; $1.1 \mathrm{~g} ; 19.5^{\circ} \mathrm{Brix} ; 3.3 \mathrm{pH}$; TA of $10.5 \mathrm{~g} \cdot \mathrm{L}^{-1}$. Cluster: range from 68-122 g. Vine: pronounced upright; budbreak between Traminette and Concord; bud hardiness averages $-25{ }^{\circ} \mathrm{C}$ in Geneva; highly resistant to powdery (Erysiphe necator) and downy mildew (Plasmopora viticola) as well as Botrytis bunch rot (Botrytis cinerea).

Aromella. Cold hardy, aromatic white wine grape. Origin: Cornell University, Geneva, NY, by B.I. Reisch, R.S. Luce, and A.K. Mansfield. Ravat $34 \times$ Traminette; tested as NY76.0844.24; crossed 1978; selected 1990; introd. 2013. Fruit: white; small; $1.53 \mathrm{~g} ; 19.5^{\circ} \mathrm{Brix}$; $\mathrm{pH} 3.0$, TA of $12 \mathrm{~g} \cdot \mathrm{L}^{-1}$; aromatic muscat, ripens mid-season in Geneva, NY. Cluster: 122 g; long, loose. Vine: semitrailing, budbreak before Traminette, after Concord; bud hardiness averages $-26{ }^{\circ} \mathrm{C}$ in Geneva; moderately resistant to powdery and downy mildew; sensitive to $2,4-\mathrm{D}$.
C51-63. Red, seedless fresh-market table grape. Origin: USDA-ARS, Parlier, CA by D.W. Ramming and R. Tarailo; C66-144 $\times$ Crimson Seedless; crossed 1988; selected 1991; introd. 2012. Fruit: red; 4.7 to $5.3 \mathrm{~g}$ ungirdled, 5.7-6.6 g girdled; oval to elliptical; firm texture; seedless. Cluster: large; conical and uniform; 680-900 g; ripens with Crimson Seedless. Vine: highly vigorous; $27 \mathrm{~kg}$ yield per vine.

\section{Cotton Candy ${ }^{\mathrm{TM}}$. See IFG Seven.}

Faith. Black, seedless, fresh-market table grape. Origin: University of Arkansas Division of Agriculture, Fayetteville, AR, by J.R. Clark and J.N. Moore. Ark.1962 × Jupiter; tested as Ark. 2412; crossed 1990; selected 1992; introd. 2012. USPP applied for. Fruit: black; medium; oval; seedless with very small seed traces; tender skin; resists cracking; neutral flavor; soluble solids $19^{\circ}$ Brix; ripens early, late July in Arkansas. Cluster: $250 \mathrm{~g}$; conical to cylindrical; wellfilled. Vine: moderate vigor; hardy to $-15^{\circ} \mathrm{C}$ to possibly colder; less susceptible to downy mildew (Plasmopora viticola) than Jupiter.

Gratitude. White, seedless, fresh-market table grape. Origin: University of Arkansas Division of Agriculture, Fayetteville, AR, by J.R. Clark and J.N. Moore. Ark. $1925 \times$ Ark. 1581; tested as Ark. 2505; crossed 1990; selected 1994; introd. 2012. USPP applied for. Fruit: white; medium; elliptical to narrow-elliptical; seedless with no seed trace; tender skin; crisp; resists cracking; neutral flavor; soluble solids $20^{\circ}$ Brix; ripens mid season, mid to late August in Arkansas. Cluster: $450 \mathrm{~g}$; conical to cylindrical; tightly filled. Vine: moderate vigor; hardy to $-15^{\circ} \mathrm{C}$ to possibly colder; very productive.

Hope. White, seedless, fresh-market table grape. Origin: University of Arkansas Division of Agriculture, Fayetteville, AR, by J.R. Clark and J.N. Moore. Ark. $1562 \times$ Ark. 1704; tested as Ark. 2053; crossed 1983; selected 1986; introd. 2012. USPP applied for. Fruit: white; medium-small; narrow-elliptic; seedless with no seed trace; tender skin; soft; resists cracking; fruity flavor; soluble solids $19{ }^{\circ}$ Brix; ripens mid season, mid to late August in Arkansas. Cluster: 300 g; conical; well-filled. Vine: moderate vigor; hardy to $-15{ }^{\circ} \mathrm{C}$ to possibly colder; consistently highly productive.

IFG Eight (Sweet Enchantment ${ }^{\mathrm{T} M}$ ). Black, seedless fresh-market table grape. Origin: International Fruit Genetics LLC, Bakersfield CA by D. Cain; Summer Royal $\times$ Regal; crossed 2004; selected 2006; USPP 23,315, 8 Jan. 2013. Fruit: black; oval; 8.4 g without girdling or GA treatment; seedless Cluster: medium density; $1154 \mathrm{~g}$; conical; early ripening Vine: medium size and vigor.

IFG Five (Sweet Jubilee ${ }^{\mathrm{TM}}$ ). Black, seedless fresh-market table grape. Origin: International Fruit Genetics LLC, Bakersfield CA by D. Cain; Redglobe $\times$ Summer Royal; crossed 2001; selected 2003; USPP 23,398 19 Feb. 2013. Fruit: black; elongated; oval; $12.8 \mathrm{~g}$ without girdling or treatment with GA; seedless. Cluster: medium density; 1422 g; circular to cylindrical; ripens mid-season. Vine: large, medium vigor.

IFG Nine (Jack's Salute ${ }^{\mathrm{TM}}$ ). Red, seedless fresh-market table grape. Origin: International Fruit Genetics LLC, Bakersfield CA by D. Cain; Redglobe $\times$ Princess; crossed 2001; selected 2003; USPP 23,$744 ; 16$ July 2013. Fruit: red; 6.9 g without girdling or treatment with GA; circular; seedless Cluster: narrow ellipsoid to cylindrical; $1.59 \mathrm{~kg}$; late-ripening. Vine: large, vigorous.

IFG Seven (Cotton Candy ${ }^{\mathrm{TM}}$ ). White, seedless fresh-market table grape with distinctive flavor. Origin: International Fruit Genetics LLC, Bakersfield CA by D. Cain; unnamed selection from the University of Arkansas A2674 × Princess; crossed 2003; selected 2005; USPP 23,399; 19 Feb. 2013. Fruit: green, 9.7 g, oval; aromatic; seedless. Cluster: 1261 g; loose; conical; ripens late-season. Vine: large, vigorous. 
IFG Six (Sweet Sapphire ${ }^{\mathrm{TM}}$ ). Black, seedless fresh-market table grape. Origin: International Fruit Genetics LLC, Bakersfield CA by D. Cain; Beita Mouni $\times$ unnamed USDA selection C22-121; crossed 2004; selected 2006; USPP 23,531; 16 Apr. 2013. Fruit: black; extremely elongated; narrow diameter; $10 \mathrm{~g}$; seedless. Cluster: loose; $1 \mathrm{~kg}$; ripens mid-season. Vine: large, vigorous.

\section{Jack's Salute ${ }^{\top M}$. See IFG Nine.}

Joy. Black, seedless, fresh-market table grape. Origin: University of Arkansas Division of Agriculture, Fayetteville, AR, by J.R. Clark and J.N. Moore. Ark. $1919 \times$ Ark. 1908; tested as Ark. 2494; crossed 1991; selected 1994; introd. 2012. USPP applied for. Fruit: black; small; narrow-elliptic; seedless with no seed trace; very tender skin; soft; resists cracking; fruity, unique flavor; flavor; soluble solids $19{ }^{\circ}$ Brix; ripens mid season, mid to late August in Arkansas. Cluster: 300 g; cylindrical; well-filled. Vine: moderate vigor; hardy to $-15{ }^{\circ} \mathrm{C}$ to possibly colder; consistently productive.

Sweet Enchantment ${ }^{\mathrm{TM}}$. See IFG Eight.

Sweet Jubilee $^{\mathrm{TM}}$. See IFG Five.

Sweet Sapphire $^{\mathrm{TM}}$. See IFG Six.

Tickled Pink ${ }^{\top \mathrm{TM}}$. See A-1710.

Valley Pearl. White, seedless fresh-market table grape. Origin: USDA-ARS, Parlier, CA, by D. Ramming and R. Tarailo; A60-42 x C77-79; crossed 1996; selected1999; introd. 2013; USPP 23,422 26 Feb. 2013. Fruit: white; round; fir; 7.2 g; seedless. Cluster: 1112 g; conical; medium density. Vine: approximately 124 clusters/vine if spur pruned; ripens early to mid-season in Parlier, CA.

\section{LIGONBERRY - Vaccinium vitis-ideae}

\section{Mark K. Ehlenfeldt, USDA-ARS, Genetic Improvement of Fruits and Vegetables Laboratory, Beltsville, MD}

Red Candy. Large-fruited lingonberry with an abundance of berries. Origin: Son \& Koot Nurseries, the Netherlands by J.A.M. Koot. Unnamed proprietary cultivar (unpatented) $\times$ Aalshorse; crossed in 2004; selected 2006; introduced 2011; USPP 22,105 P2. Fruit: large; deep red, $\sim 1.2 \mathrm{~cm}$; spherical; edible; acidic. Plant: evergreen foliage, compact habit, long flowering period and a large numbers of flowers; requires cross-pollination for abundant fruit production; grows well in an acid, well-drained soil in full sun or partial shade; suitable for mass planting, solitaire, groundcover, mixed container, peatbed, woodland garden, or compact hedges.

\section{NECTARINE}

Ksenija Gasic, School of Agricultural, Forest, and Environmental Sciences, Clemson University, Clemson, SC

Amoore Sweet. Yellow-fleshed, mid-early season, non/slow melting nectarine. Origin: University of Arkansas Division of Agriculture, Fayetteville, AR, by J.R. Clark. Ark. $699 \times$ Ark. 663 nectarines; crossed 2001; selected 2004; tested as Ark. 765; introd. 2012. USPP applied for. Fruit: med., 150 g; round; low acid, pH 4.1 and $0.29 \%$ malic acid, $17{ }^{\circ}$ Brix; very firm flesh that is classified as non/slowmelting; $80 \%$ blush with yellow ground color, ripens early July in Arkansas, near or just after Redhaven. Tree: flower non-showy, selffertile; chilling requirement estimated at $800 \mathrm{~h}$; leaf glands reniform and located near the base of the leaf blade on the top of the petiole; resistant to bacterial spot; hardy with good flower bud survival with mid-winter lows of $-17^{\circ} \mathrm{C}$.
ASFNBF0688. White-fleshed, semi-clingstone flat nectarine. Origin: S.A.R.L. Argo Selection Fruits, Elne, France by L. Maillard and A. Maillard. Redpearl × Flataugust; USPP 22,492; 14 Feb. 2012. Fruit: medium to large, $170 \mathrm{~g}$; uniform; round and flattened; luminous red overcolor covers $80-90 \%$ of red ground color; flesh white with a star-shaped red pigmentation; semi-sweet, very aromatic; firm, melting; even slow maturing; long shelf life; ripens 25 Aug.-1 Sept. in the Pyrenees-Orientales department, France. Tree: large, vigorous, very productive, semi-spread to semi-upright, medium dense; flowers medium to large, showy; self-fertile; 600-1201 chill hours; leaf glands medium, reniform.

Bowden. White-fleshed, mid-early season, non-melting nectarine. Origin: University of Arkansas Division of Agriculture, Fayetteville, AR, by J.R. Clark. Ark. $699 \times$ Ark. 663 nectarines; crossed 2001; selected 2004; tested as Ark. 764; introd. 2012. USPP applied for. Fruit: med., 150 g; round; standard acid, $\mathrm{pH} 3.4$ and $0.84 \%$ malic acid, $15^{\circ} \mathrm{Brix}$; very firm flesh that is classified as non-melting; $75 \%$ blush with white to creamy ground color, ripens early July in Arkansas, near or just after Redhaven. Tree: flower non-showy, self-fertile; chilling requirement estimated at $800 \mathrm{~h}$; leaf glands reniform and located near the base of the leaf blade on the top of the petiole; resistant to bacterial spot; hardy with good flower bud survival with mid-winter lows of $-17^{\circ} \mathrm{C}$.

Cakelove. White-fleshed, freestone flat nectarine. Origin: S.A.R.L. Argo Selection Fruits, Elne, France by A. Maillard and L. Maillard. Nectarmagie $\times$ Flatnice; USPP 24,107; 24 Dec. 2013. Fruit: mediumlarge; flat-oblate; uniform; red ground color with purple red blush; flesh white with pink pigmentation; semi-sweet, very long self-life; ripens 30 June-19 July in the Pyranees-Orientales department, France. Tree: vigorous, large, half-standing, in semi-spread to semi-upright; flowers large, showy, self-fertile; 600-1200 chill hours; leaf glands globose.

Cakepearl. White-fleshed, clingstone nectarine. Origin: S.A.R.L. Argo Selection Fruits, Elne, France by L. Maillard and A. Maillard. Flatnice $\times$ Nectarmagie; USPP 23,356; 29 Jan. 2013. Fruit: very large; flat; bright purple red color on washed-pink red ground; flesh white with red; very firm and very dense; semi-sweet; ripens 15 July-24 July in the Pyrenees-Orientales department, France. Tree: medium to high; vigorous; very productive; semi-spread and semi-upright; medium dense to dense; hardy; very frost resistant; flowers medium to large; showy; self-fertile; 350-1200 chill hours; leaf glands medium round.

Cakeredal. White-fleshed, clingstone nectarine. Origin: S.A.R.L. Argo Selection Fruits, Elne, France by L. Maillard and A. Maillard. Nectarcrisp O.P.; USPP 23,358; 29 Jan. 2013. Fruit: very large; oblate; bright purple red color on washed-pink red ground; flesh white with slight pink; very firm and very dense; semi-sweet; ripens 23 July-1 Aug. in the Pyrenees-Orientales department, France. Tree: medium to high; vigorous; very productive; semi-spread and semi-upright; medium dense to dense; hardy; very frost resistant; flowers medium to large; showy; self-fertile; 350-1200 chill hours; leaf glands medium reniform.

Fire Time. Yellow-fleshed, clingstone nectarine. Origin: Le Grand CA by L.G. Bradford. Western Pride $\times$ Grand Bright; USPP 22,741; 22 May 2012. Fruit: large, $255 \mathrm{~g}$; uniform; globose to slightly asymmetrical; deep red overcolor smoothly blending into a deep reddish orange ground color with some very deep red mottling spots and moderate orange yellow freckling towards apex; flesh yellow with some deep red streaking throughout; semi-clingstone; firm, melting, juicy; acidic; ripens 1-10 Aug., in San Joaquin Valley, CA. Tree: medium; moderately vigorous; upright and dense; flowers large showy; self-fertile; 650 chill hours; leaf glands reniform.

Nectardream. White-fleshed, clingstone nectarine. Origin: S.A.R.L. Argo Selection Fruits, Elne, France by L. Maillard and 
A. Maillard. Nectarmagie $\times$ Nectarcrisp; USPP 23,420; 26 Feb. 2013. Fruit: very large; round; skin purple red color on a pink red ground; flesh white with a slight pink red; very firm and very dense; semi-sweet; very juicy; ripens 23 July-8 Aug. in the PyreneesOrientales department, France. Tree: medium; vigorous; very productive; semi-spread to semi-upright; hardy; very frost resistant; flowers medium to large; showy; self-fertile; 350-1200 chill hours; leaf glands medium round.

Nectarlove. White-fleshed, clingstone nectarine. Origin: S.A.R.L. Argo Selection Fruits, Elne, France by L. Maillard and A. Maillard; Nectarmagie $\times$ Nectarcrisp; USPP 23,419; 26 Feb. 2013. Fruit: large; round; skin bright purple red color on a washed-pink cream ground; flesh white with a slight pink red; very firm and very dense; semi-sweet; ripens 8-18 Aug. in the Pyrenees-Orientales department, France. Tree: medium to high; vigorous; very productive; semispread and semi-upright; medium dense to dense; hardy; very frost resistant; flowers medium to large, showy; self-fertile; 350-1200 chill hours; leaf glands medium reniform.

Nectarperf. White-fleshed, clingstone nectarine. Origin: S.A.R.L. Argo Selection Fruits, Elne, France by L. Maillard and A. Maillard. Nectarmagie $\times$ Nectarcrisp; USPP 23,357; 29 Jan. 2013. Fruit: very large; round; bright purple red color on washed-pink red ground; flesh white with red; very firm and very dense; semi-sweet; ripens 5-12 Sept. in the Pyrenees-Orientales department, France. Tree: medium to high; vigorous; very productive; semi-spread and semiupright; medium dense to dense; hardy; very frost resistant; flowers medium to large; showy; self-fertile; 350-1200 chill hours; leaf glands medium reniform.

Nectarruby. White-fleshed, clingstone nectarine. Origin: S.A.R.L. Argo Selection Fruits, Elne, France by L. Maillard and A. Maillard. Nectarcrisp $\times$ 02.10.53NB-ASF0327; USPP 23,421; 26 Feb. 2013.

Fruit: large to very large; round; very firm and very dense; flesh is white with a slight pink and a slight red; bright purple red color on a pink-washed red ground; semi-sweet; very juicy; ripens 15-25 Aug. in the Pyrenees-Orientales department, France. Tree: large; strong vigor; very productive; hardy; very resistant to frost; semi-spreading and semi-upright; flowers medium to large; showy; self-fertile; 350 1200 chill hours; leaf glands medium reniform.

Nectartic. White-fleshed, clingstone nectarine. Origin: S.A.R.L. Argo Selection Fruits, Elne, France by L. Maillard and A. Maillard. Nectarcrisp × JMD 5 NB; USPP 23,442; 5 Mar. 2013. Fruit: large; round; bright purple red blush covers $90-100 \%$ on pink red ground; white flesh; very firm and very dense; juicy; semi-sweet; ripens 27 Aug.-6 Sept. in the Pyrenees-Orientales department, France. Tree: large; vigorous; semi-spreading and semi-upright; very productive; hardy; very frost resistant; medium dense to dense; flowers large; showy; self-fertile; 350-1200 chill hours; leaf glands medium reniform.

Pearl Time. White-fleshed, freestone sub-acid nectarine. Origin: Le Grand CA by L.G. Bradford. Snow Princess $\times$ Spring Bright; USPP 22,471; 31 Jan. 2012. Fruit: medium, 190g; uniform; round to slightly oval; dark red over a very red ground color with light orange yellow freckling on the sides and towards apex; flesh white to greenish-white, with slight amount of deep pink bleeding close to the stone; very firm, melting; sub-acid, sweet; ripens 22 June to 4 July near Le Grand, CA, in Merced County (San Joaquin Valley). Tree: medium, moderately vigorous, half-hardy, very productive, spreading and dense; flowers large, showy; 500 chill hours; leaf glands small, globose.

Pearlicious I. White-fleshed, clingstone nectarine. Origin: Le Grand CA by L.G. Bradford. Candy Pearl $\times$ Spring princess; USPP 22,758; 29 May 2012. Fruit: large (190g); uniform; globose compressed axially; dark red over a dark reddish orange ground color with light moderate orange yellow freckling toward the apex; white flesh; semi-freestone, firm, dense, meaty; sub-acid and sweet (14-20 brix); ripens 4-14 June in San Joaquin Valley, CA. Tree: medium; moderately vigorous; spreading and dense; flowers large showy; selffertile; 350 chill hours; leaf glands medium reniform.

Pearlicious II. White-fleshed, clingstone nectarine. Origin: Le Grand CA by L.G. Bradford. Rose Diamond $\times$ unnamed white flesh nectarine; USPP 22,759; 29 May 2012. Fruit: large; uniform; globose; dark red over a very red ground color with pale orange yellow freckling on the sides; greenish white flesh; firm, meaty, semimelting; sweet and sub-acid; ripens 8-20 June in San Joaquin Valley, CA. Tree: large; vogorous; spreading and dense; flowers large, showy, self-fertile; 500 chill hours; leaf glands small reniform.

Pearlicious VI. White-fleshed, clingstone nectarine. Origin: Le Grand CA by L.G. Bradford. 6P740 × Dimaond Pearl; USPP 23,607; 21 May 2013. Fruit: very large; globose; clingstone; firm and melting; dark red over a moderate red background with heavy pale yellow green; greenish white; freckling acid and sugar; ripens 2 July-16 July in San Joaquin Valley, CA. Tree: medium, vigorous, hardy, spreading and dense, productive; flowers showy; self-fertile; 525 chill hours; leaf glands medium reniform.

Pearlicious VII. White-fleshed, clingstone nectarine. Origin: Le Grand CA by L.G. Bradford. June Pearl $\times 1$ P1152; USPP 23,608; 21 May 2013. Fruit: uniform; large; globose; clingstone; firm and melting; yellowish white flesh color with a minor amount of light pink; dark red over a strong red background with pale orange yellow freckling; acid and sugar; ripens 7 July-21 July in San Joaquin Valley, CA. Tree: large, very vigorous, spreading and dense, hardy, productive; flowers large; showy; self-fertile; 550 chill hours; leaf glands large globose.

\section{PEACH}

\section{Ksenija Gasic, SAFES, Clemson University, Clemson, SC}

ASFNBF0796. White-fleshed, semi-clingstone slow maturing, flat peach. Origin: S.A.R.L. Argo Selection Fruits, Elne, France by L. Maillard and A. Maillard. Nectarmagie $\times$ ASFPBF0493; USPP 22,495; 14 Feb. 2012. Fruit: medium to large, 150-200 g; uniform; round and flattened; luminous red overcolor covers more than $95 \%$ of orange white ground color; flesh white with red pigmentation near the stone; semi-sweet, very aromatic; firm, melting; even slow maturing; long shelf life; ripens 25 July to 4 Aug. in the PyreneesOrientales department, France. Tree: large, moderately vigorous, very productive, semi-spread to semi-upright, medium dense; flowers medium, showy; self-fertile; 600-1200 chill hours; leaf glands medium, reniform.

ASFNBF0798. White-fleshed, semi-clingstone slow maturing flat peach. Origin: S.A.R.L. Argo Selection Fruits, Elne, France by L. Maillard and A. Maillard. Nectarmagie $\times$ ASFPBF0492; USPP 22,496; 14 Feb. 2012. Fruit: medium to large, $170 \mathrm{~g}$; uniform; round and flattened; luminous red overcolor covers $80-90 \%$ of pink red ground color; flesh white; semi-sweet, very aromatic; firm, melting; even, slow maturing; long shelf life; ripens 14-25 Aug. in the Pyrenees-Orientales department, France. Tree: large, vigorous, very productive, semi-spread to semi-upright, medium dense; flowers medium, showy; self-fertile; 600-1200 chill hours; leaf glands medium, reniform.

Aspen White. White-fleshed, clingstone peach. Origin: Modesto, CA by G.N. Zaiger, L.M. Gardner and G.G. Zaiger. 7LL330 $\times$ 396LN233; USPP 23,609; 21 May 2013. Fruit: large; globose; firm and meaty; clingstone; flesh white with yellow ground color and red blush; moderately juicy; bitter taste; ripens 7-17 June in Modesto CA. Tree: large, vigorous; productive; upright and medium dense; 
hardy; flowers large; showy; self-fertile; 600 chill hours; leaf glands medium-large; reniform.

Burpeachtwentyeight. Yellow-fleshed, medium-small, early ripening clingstone peach. Origin: The Burchell Nursery Inc. Oakdale, CA by T.J. Gerdts, J.K Slaughter. Spring Gem $\times$ B17.013; USPP 23,689; 25 June 2013. Fruit: large; uniform; round; red blush covers $80-90 \%$ of surface, yellow ground color; flesh orange yellow; firm, dense; melting; very sweet; even ripening; ripens 17-24 May in Fowler, CA. Tree: medium; moderately vigorous; upright; moderately dense; productive; flowers large; showy; self-fertile; 650 chill hours; leaf glands small reniform.

Burpeachtwentyfive. Red-fleshed, clingstone early ripening peach. Origin: The Burchell Nursery Inc. Oakdale, CA by J.K. Slaughter and T.J. Gerdts. Burpeachtwentytwo $\times$ unpatented peach; tested as N26.033; USPP 22,605; 27 Mar 2012. Fruit: large, 202 g; uniform; round; red overcolor covering $80-90 \%$ of yellow ground color; flesh color is mixture of red and orange yellow; firm, juicy, dense, nonmelting; sweet and moderately acidic, balanced taste; ripens 8-15 May in San Joaquin Valley, CA. Tree: medium to medium-small, vigorous; upright, moderately dense; flowers large, showy; self-fertile; 250 chill hours; leaf glands small reniform.

Burpeachtwentyseven. Yellow-fleshed, non-melting clingstone peach. Origin: The Burchell Nursery Inc. Oakdale, CA by J.K. Slaughter and T.J. Gerdts. Parentage unknown; tested as E8.017; USPP 23,160; 6 Nov 2012. Fruit: large, uniform; slighty oblate; red over color covering $80-90 \%$ of yellow ground color; flesh orange yellow; firm, juicy melting; sweet and moderately acidic; ripens 12-19 June in San Joaquin Valley, CA. Tree: medium to medium large; vigorous; upright; moderatey dense; flowers large, showy, selffertile; 650 chill hours; leaf glands small reniform.

Burpeachtwentysix. Yellow-fleshed, non-melting freestone peach. Origin: The Burchell Nursery Inc. Oakdale, CA by J.K. Slaughter and T.J. Gerdts. E62.012 × E48.050; tested as P4.099; USPP 23,161; 6 Nov 2012. Fruit: large; uniform; slightly oblate; red overcolor covering $70-80 \%$ of yellow ground color; flesh orange yellow, can develop reddish color at the outer margin of the pit cavity that can radiate into the flesh; firm, juicy non-melting; sweet and moderate to low acidic; ripens 10-17 Aug. in San Joaquin Valley, CA. Tree: medium to medium large, vigorous; upright and moderately dense; flowers showy; self-fertile; 550 chill hours; leaf glands small reniform.

Burpeachtwentythree. Yellow-fleshed, low chill, early ripening, clingstone peach. Origin: The Burchell Nursery Inc., Oakdale, CA by J.K. Slaughter and T.J. Gerdts. unpatented clingstone peach $\times$ Tropic Beauty; tested as J40.111; USPP 22,780; 12 June 2012. Fruit: large; uniform; round; red overcolor covering $70-80 \%$ of yellow ground color; flesh yellow; firm, juicy, dense, non-melting; mildly acidic and sweet; ripens 5-10 May July in San Joaquin Valley, CA. Tree: large, vigorous; upright and dense; flowers showy; self-fertile; 175 chill hours; leaf glands small reniform.

Candy Cane. Large, peppermint-type flower, ornamental peach. Origin: Warner Robins, GA by W. Okie. BY89P4594 selfed; USPP 23,443; 5 Mar. 2013. Fruit: small; firm, non-melting; light yellowgreen skin; clingstone; taste inferior to commercial; ripens mid Aug. in Byron, GA. Tree: medium; semi-spreading and rounded; moderately vigorous; hardy; very rarely produces; homozygous for red leaf (GrGr), red flower (rr), double flower (dd), and unstable white flower (w.sup.vw.sup.v); flowers large, double showy; mostly infertile; 850 chill hours; leaf glands medium reniform.

Crispbella. Yellow-fleshed, clingstone peach. Origin: S.A.R.L. Argo Selection Fruits, Elne, France by L. Maillard and A. Maillard. Nectarprima $\times$ Maillarbo; USPP 23,198; 20 Nov. 2012. Fruit: large; round to slightly oblong; red blush covers $100 \%$ of surface; flesh yellow with red; very firm and very dense; semi-sweet; very juicy; ripens 5-16 July in the Pyrenees-Orientales department, France. Tree: medium to high; vigorous; very productive; semi-spread and semi-upright; medium dense to dense; hardy; very frost resistant; flowers small; non-showy; self-fertile; 350-1200 chill hours; leaf glands medium reniform.

Flatbeauti. White-fleshed, clingstone frost resistant peach. Origin: S.A.R.L. Argo Selection Fruits, Elne, France by L. Maillard and A. Maillard. Flatpretty $\times$ Nectarmagie; USPP 23,197; 20 Nov. 2012. Fruit: large; round and oblate; bright red overcolor covering an orange red groundcolor; flesh white with a red pigmentation; semisweet; very firm and very dense; very juicy; ripens $15-23$ July in the Pyrenees-Orientales department, France. Tree: medium to high; vigorous; very productive; semi-spread and semi-upright; medium dense to dense; hardy; very frost resistant; flowers medium to large; showy; self-fertile; 350-1200 chill hours; leaf glands reniform.

Flatbella. White-fleshed, clingstone mid-season peach. Origin: S.A.R.L. Argo Selection Fruits, Elne, France by L. Maillard and A. Maillard. Flatpretty $\times$ Nectarmagie; USPP 23,194; 20 Nov 2012. Fruit: large; round and oblate; bright red color on an orange red ground; flesh white with a red pigmentation; semi-sweet; very firm and very dense; very juicy; ripens 7-16 July in the Pyrenees-Orientales department, France. Tree: medium to high; vigorous; very productive; semi-spread and semi-upright; medium dense to dense; hardy; very frost resistant; flowers medium to large; showy; self-fertile; 3501200 chill hours; leaf glands reniform.

Glacier Princess. White-fleshed, freestone late ripening peach. Origin: Le Grand CA by L.G. Bradford. 52P566 × Snow Duchess; USPP 23,867; 3 Sept. 2013. Fruit: large, globose; freestone; firm, melting; white flesh, red to pink in skin color; lightly acidic ; ripens 13-27 Sept. in San Joaquin Valley, CA. Tree: medium to weak vigor; upright and dense; hardy; flowers large; showy; self-fertile; 475 chill hours; leaf glands reniform.

Glacier Queen. White-fleshed, firm, freestone, subacid peach. Origin: Le Grand CA by L.G. Bradford. Snow Princess $\times 3$ P1236; USPP 23,868; 3 Sept. 2013. Fruit: very large; uniform; globose; deep red overcolor smoothly blending into light yellowish pink; flesh white with dark red streaking toward stone with maturity; firm, melting; sweet, subacid; ripens 24 Aug.-5 Sept. in San Joaquin Valley, CA. Tree: large; vigorous; spreading and dense; hardy ; flowers large, showy; self-fertile; 450 chill hours; leaf glands globose.

Ivory May. White-fleshed, clingstone peach. Origin: Le Grand CA by L.G. Bradford. 32P462 × 53P100; USPP 23,866; 3 Sept. 2013 Fruit: uniform, medium; globose; clingstone; firm, melting; flesh yellowish white; dark red overcolor covering light orange yellow ground color; ripens 20 May-3 June in San Joaquin Valley, CA. Tree: large; vigorous; spreading and dense; vase type; hardy; flowers large, showy; self-fertile; 550 chill hours; leaf glands medium reniform.

Jin Yu. White-fleshed, sweet semi-freestone peach. Origin: Pomology Institute, Shanxi Academy of Agricultual Sciences, by S. Chen, L. Huang, B. Dong and P. Yang. Zhao Hui $\times$ Okayama Early; Introduced in 2013; registered in Shanxi province on July 2013. Fruit: large; comparatively uniform, red overcolor covering $80 \%$ of greenish white ground color with deep dark red spot near the suture; moderate pubescence; flesh milky white, soft, very good, sweet; semifreestone, no red near pit; ripens late June to early July in Jin Zhong Shanxi province. Tree: medium, vigorous, more upright, productive; flowers medium, nonshowy pink.

June Time. Yellow-fleshed, clingstone peach. Origin: Le Grand CA by L.G. Bradford. Parentage unknown; USPP 23,530; 16 Apr. 2013. 
Fruit: uniform; large; acidic; globose; clingstone; firm and nonmelting; yellow with red bleeding in flesh color; mostly dark red in skin color; ripens 16-26 June in San Joaquin Valley, CA. Tree: large; vigorous; hardy; spreading and dense; productive; flowers large; showy; self-fertile; 600 chill hours; leaf glands small reniform.

Kodiak. Yellow-fleshed, clingstone low acid peach. Origin: Modesto CA by G.N. Zaiger, L.M. Gardner and G.G. Zaiger. 36ZD906 (Sugar Lady, Ricj Lady, Country Sweet, Earlitreat, 92ED535) O.P.; USPP 23,004; 4 Sept. 2012. Fruit: large; globose; high degree of attractive red skin color over yellow ground color; flesh yellow, firm and meaty; low acid, sweet; good storage and shipping quality; ripens 3-10 June near Modesto, Stanislaus County, CA. Tree: large, vigorous, upright; flowers large showy; self-fertile; 700 chill hours; leaf glands small to medium, reniform.

NJ354. White-fleshed, clingstone low acid peach. Origin: Rutgers, The State University, New Brunswick, NJ by J.C. Goffreda and A.M. Voordeckers. NJ318 × White Lady; USPP 23,669; 18 June 2013. Fruit: large; uniform; round; slightly mottled red-purple over a red blush covering red ground color; flesh green-white flecked with red; firm and melting; sweet with little acidity; ripens 14-30 July in Cream Ridge, NJ. Tree: moderately vigorous; spreading; flowers small, non-showy; self-fertile; leaf glands reniform.

NJ355. Greyed-white-fleshed, clingstone, non-melting peach. Origin: Rutgers, The State University, New Brunswick, NJ by J.C. Goffreda and A.M. Voordeckers. J19-19-862144 O.P.; USPP 23,883; 10 Sept. 2013. Fruit: medium; uniform; nearly round slightly oblong; mottled red and greyed purple overcolor covering orange white ground color; flesh greyed-white, becoming greyed yellow near the stone; very firm, non-melting; sweet and slightly acidic; excellent keeping and shipping quality; ripens 11-31 July in Cream Ridge, NJ. Tree: medium to large; moderately vigorous and spreading; flowers non-showy, large; self-fertile; leaf glands reniform.

NJ356. Yellow-fleshed, freestone, subacid peach. Origin: Rutgers, The State University, New Brunswick, NJ by J.C. Goffreda and A.M. Voordeckers. D90-9 × NJ318; USPP 23,884; 10 Sept. 2013. Fruit: large; round; mottled red overcolor covering orange white ground color; flesh yellow-white; firm; melting; subacid; ripens 18 Aug.10 Sept. in Cream Ridge, NJ. Tree: medium; vigorous; winter hardy; moderately spreading; very productive; flowers non-showy; selffertile; leaf glands reniform.

Polar Princess. White-fleshed, freestone peach. Origin: Le Grand CA by L.G. Bradford. 5P495 × Snow Princess; USPP 23,723; 9 July 2013. Fruit: very large, uniform; globose; deep red ovecolor covering yellowish white ground color; flesh pinkish white acquiring some moderate red streaking; sub-acidic, freestone, firm and melting; ripens 21 July-4 Aug. in San Joaquin Valley, CA. Tree: medium; medium vigor; upright and dense; hardy; very productive; flowers large; showy; self-fertile; 500 chill hours; leaf glands large reniform.

Sauzee Lady. White-fleshed, clingstone flat peach. Origin: Zeiger CA by G.N. Zeiger, L.M. Gardner, G.G. Zeiger. 52LA314 (Fayette, Royal Gold, Redwig, Sugar Lady, Red Grand) × 333LH428 (Carolyn, Fayette, May Grand and peento); USPP 22,404; 27 Dec. 2011. Fruit: medium to large, $173 \mathrm{~g}$; round flattened; attractive light red blush; flesh white; firm, meaty; sweet, sub-acid; ripens 2-8 Aug. near Modesto, Stanislaus County, CA. Tree: large, vigorous, upright, medium dense; flowers large, showy; 800 chill hours; leaf glands small to medium, reniform.

Sitka. White-fleshed, clingstone low acid peach. Origin: Modesto CA by G.N. Zaiger, L.M. Gardner and G.G. Zaiger. 172LE55 × 54Z432; USPP 23,799; 6 Aug. 2013. Fruit: large; uniform; round; ground color pale yellow with red-orange blush; firm; mild sweet, low acid; ripens 30 May-6 June in Modesto, CA. Tree: large, vigorous; upright; medium dense; productive; hardy; flowers large; showy; selffertile; 500 chill hours; leaf glands large reniform.

Souvenirs. Yellow-fleshed, mid-early season freestone, slow melting peach. Origin: University of Arkansas Division of Agriculture, Fayetteville, AR, by J.R. Clark. Ark. $708 \times$ Winblo; crossed 2001; selected 2004; tested as Ark. 763; introd. 2012. USPP applied for. Fruit: med.-large, $180 \mathrm{~g}$; round; low acid, $\mathrm{pH} 4.5$ and $0.26 \%$ malic acid, $14{ }^{\circ}$ Brix; very firm flesh that is classified as slow-melting, which is very firm until fully mature then softens to melting; freestone; $90 \%$ blush with yellow ground color, ripens early July in Arkansas, near or just after Redhaven. Tree: flower large, showy, self-fertile; 800 chill hours; leaf glands reniform and located near the base of the leaf blade on the top of the petiole; resistant to bacterial spot (Xanthomonas campestris pv. pruni); hardy with good flower bud survival with mid-winter lows of $-17^{\circ} \mathrm{C}$.

Spring Fire. Yellow-fleshed, early ripening, clingstone peach. Origin: Zeiger, CA by G.N. Zeiger, L.M. Gardner, G.G. Zeiger. 202LK334 (Royal Glo, Fayette, Royal April, Ruby Giold, May Glo) $\times$ 58ZA724 (Honey Kist, Bonita, May Grand, May Glo, May Crest, Desert Gold, 3W11); USPP 22,278; 29 Nov. 2011. Fruit: medium, $145 \mathrm{~g}$; globose; attractive red skin color; flesh yellow; firm, meaty; balanced taste; clingstone; ripens 8-15 May near Modesto, Stanislaus County, CA. Tree: large, vigorous, upright; flowers medium to large, reniform; 300 chill hours; leaf glands large, showy.

Supechseventeen. Yellow-orange flesh, early ripening, clingstone melting peach. Origin: Sun World International, LLC (Bakersfield, CA) by T. Bacon. Supechsix $\times$ 91-006C; USPP 22,588; 20 Mar 2012. Fruit: medium, $136 \mathrm{~g}$; rounded; medium red overcolor over dark yellow-orange ground color; flesh medium yellow-orange; firm, melting; fruit skin and pit have tendency to crack in wet seasons; ripens 4-12 May in Wasco, Kern County, CA. Tree: medium vigor, productive, semi-upright; flowers medium; leaf glands reniform.

Sweetregal. White-fleshed, clingstone peach. Origin: S.A.R.L. Argo Selection Fruits, Elne, France by L. Maillard and A. Maillard. Nectachief $\times$ Malatewhite; USPP 23,196; 20 Nov. 2012. Fruit: large; round and oblate; bright purple red color covering a washedpink red ground color; flesh white with a red pigmentation; semisweet; very firm and very dense; very juicy; ripens 3-13 Aug. in the Pyrenees-Orientales department, France. Tree: medium to large; vigorous; very productive; semi-spread and semi-upright; medium dense to dense; hardy; very frost resistant; flowers medium to large; showy; self-fertile; 350-1200 chill hours; leaf glands reniform.

Sweetreine. White-fleshed, clingstone peach. Origin: S.A.R.L. Argo Selection Fruits, Elne, France by L. Maillard and A. Maillard. Nectachief $\times$ Masnow; USPP 23,195; 20 Nov. 2012. Fruit: large; round and oblate; bright purple red overcolor covering a washedpink red ground color; flesh white with a red pigmentation; semisweet; very firm and very dense; very juicy; ripens 11-25 Aug. in the Pyrenees-Orientales department, France. Tree: medium to high; vigorous; very productive; semi-spread and semi-upright; medium dense to dense; hardy; very frost resistant; flowers, medium to large; showy; self-fertile; 350-1200 chill hours; leaf glands reniform.

UFSharp. Yellow-fleshed, non-melting clingstone peach. Origin: Florida Foundation Seed Producers, by J.X. Chaparro; Fla. 90-50 cn $\times$ Fla. 88-6; tested as Fla. 97-52c; USPP 22,294; 6 Dec. 2011. Fruit: medium large, uniform; oval; bright red overcolor covering 50-70\% of rich yellow ground color; flesh yellow; firm, juicy, melting when fully ripe; moderately sweet, slightly acid ; ripens 20-28 May in Gainesville FL. Tree: medium, moderately vigorous, upright; flowers showy; 350 chill hours; leaf glands globose.

White Diamond. White-fleshed, freestone, late-season, sub-acid peach. Origin: University of Arkansas Division of Agriculture, 
Fayetteville, AR by J.R. Clark and J.N. Moore. Ark. $392 \times$ White River; USPP 22,464; 24 Jan. 2012. Fruit: medium-large, 200-230g; uniform; rounded with slight suture bulge; red overcolor covering $87 \%$ of yellow ground color; flesh white; very firm, melting; sweet, low-acid; resistant to bacterial spot; ripens 29 July to 10 Aug. in Clarksville, AR. Tree: vigorous; semi-upright; resistant to bacterial spot; flowers showy; leaf glands reniform.

Zee Pride. Yellow-fleshed, early-season, cllingstone peach. Origin: Zeiger CA by G.N. Zeiger, L.M. Gardner, G.G. Zeiger. Vista Rich $\times$ 57EE22 (Sierra Rich $\times$ Country Sweet); tested as 175LE263; USPP 22,606; 27 May 2012. Fruit: large; globose; uniform; attractive red overcolor covering $80-90 \%$ of yellow ground color; flesh yellow; firm, meaty; balanced taste; ripens 20 days before Sierra Rich in Modesto, CA. Tree: large, vigorous; upright; flowers large showy; 850 chill hours; leaf glands large, reniform.

\section{PEACH ROOTSTOCK}

Thomas G. Beckman, USDA-ARS Southeastern Fruit and Tree Nut Res. Lab. Byron, GA

Controller $^{\circledR}$ 6. See HBOK 27.

Controller $^{\circledR}$ 7. See HBOK 32.

Controller $^{\circledR}$ 8. See HBOK 10.

\section{Controller ${ }^{\circledR}$ 9.5. See HBOK 50.}

Densipac (Rootpac $\left.{ }^{\circledR} 20\right)$. Clonal plum hybrid rootstock for peach and nectarine. Origin: Agromillora Catalana, Barcelona, Spain. Prunus besseyi $\times$ P. cerasifera (both unpatented and unnamed clones); selected in 1998 by J. Pinochet; tested as PAC 9801-02; introduced 2011. USPP 23,865; 3 Sept., 2013. Plant: propagated easily via tissue culture; unbudded tree is low vigor with a semierect, compact form; medium chilling requirement $(600-800 \mathrm{cu})$; reproductively sterile. Rootstock performance: low vigor, similar to GF655-2; advances fruit maturity and increases fruit size compared to peach rootstocks; little or no rootstock suckering; tolerant of calcareous soils and asphyxia; moderate resistance to root-knot nematode (Meloidogyne spp.); resistant to lesion nematode populations (Pratylenchus vulnus); resistant to Rosellinia necatrix root fungus; good compatibility with peach and nectarine varieties.

HBOK 10 (Controller ${ }^{\circledR}$ 8). Clonal peach hybrid rootstock for peach and nectarine. Origin: University of California, Davis, CA. Prunus persica $\mathrm{F}_{2}$ hybrid from P248-139O.P. (Harrow Blood $\times$ Okinawa; both unpatented); tested as 94-94-10; introduced 2010. USPP 22,505; 21 Feb., 2012. Plant: propagated via leafy cuttings, hardwood cuttings or tissue culture; unbudded tree has a lower chilling requirement than typical Californian peach cultivars; reniform leaf glands; and showy flowers; fruit freestone with little, if any, red blush; flesh white. Rootstock performance: low to moderate vigor, ca. $60 \%$ the size of trees on Nemaguard; yield efficiency comparable to trees on Nemaguard at first but gradually improving as trees age; little or no reduction in fruit size compared to trees on Nemaguard; very few root suckers; good anchorage; (heterozygous) resistant to root-knot nematode (Meloidogyne incognita); lower reproduction of lesion nematode (Pratylenchus vulnus) compared to Nemaguard; good compatibility with peach and nectarine varieties tested.

HBOK 27. (Controller ${ }^{\circledR}$ 6). Clonal peach hybrid rootstock for peach and nectarine. Origin: University of California, Davis, CA. Prunus persica $\mathrm{F}_{2}$ hybrid from P248-139 O.P. (Harrow Blood $\times$ Okinawa; both unpatented); tested as 94-94-27, introduced 2012. USPP 23,631; 28 May, 2013. Plant: propagated via leafy cuttings, hardwood cuttings or tissue culture; reniform leaf glands; and showy flowers; fruit freestone with little, if any, red blush; flesh white.
Rootstock performance: low to moderate vigor, ca. $50 \%$ the size of trees on Nemaguard; yield efficiency comparable to trees on Nemaguard at first but becoming significantly better as trees age; increased fruit size compared to trees on Nemaguard; very few root suckers; moderate resistance to root-knot nematode (Meloidogyne incognita); good compatibility with peach and nectarine varieties tested.

HBOK 32 (Controller ${ }^{\circledR}$ 7). Clonal peach hybrid rootstock for peach and nectarine. Origin: University of California, Davis, CA. Prunus persica $\mathrm{F}_{2}$ hybrid from P248-139 O.P. (Harrow Blood $\times$ Okinawa; both unpatented); tested as 94-94-32; introduced 2010. USPP 22,845; 10 July, 2012. Plant: propagated via leafy cuttings, hardwood cuttings or tissue culture; unbudded tree has a lower chilling requirement than typical Californian peach cultivars; reniform leaf glands; and showy flowers. Fruit is freestone with little, if any, red blush and white fleshed. Rootstock performance: low to moderate vigor, ca. $60 \%$ the size of trees on Nemaguard; yield efficiency comparable to trees on Nemaguard at first but gradually improving as trees age; small reduction in fruit size compared to trees on Nemaguard; few, if any, root suckers; (homozygous) resistant to root-knot nematode (Meloidogyne incognita); reproduction of lesion nematode (Pratylenchus vulnus) comparable to Nemaguard; good compatibility with peach and nectarine cultivars tested.

HBOK 50 (Controller ${ }^{\circledR}$ 9.5). Clonal peach hybrid rootstock for peach and nectarine. Origin: University of California, Davis, CA. Prunus persica $\mathrm{F}_{2}$ hybrid from P248-139 O.P. (Harrow Blood $\times$ Okinawa; both unpatented); tested as 94-94-50; introduced 2010. USPP 22,208; 25 Oct., 2011. Plant: propagated via leafy cuttings, hardwood cuttings or tissue culture; unbudded tree has a lower chilling requirement than typical Californian peach cultivars; reniform leaf glands; and showy flowers; fruit freestone with little, if any, red blush; flesh white. Rootstock performance: moderate vigor, comparable to or slightly lower than trees on Nemaguard; yield efficiency comparable to trees on Nemaguard; small reduction in fruit size compared to trees on Nemaguard; few, if any, root suckers; (heterozygous) resistant to root-knot nematode (Meloidogyne incognita); lower reproduction of lesion nematode (Pratylenchus vulnus) compared to Nemaguard; good compatibility with peach and nectarine varieties tested.

$\operatorname{Rootpac}^{\circledR}$ 20. See Densipac.

\section{PERSIAN WALNUT}

Charles A. Leslie, Walnut Improvement Program, University of California, Davis, CA

Solano. Early-mid season harvesting walnut with extra-light kernel color. Origin: University of California-Davis, by G. McGranahan and C. Leslie. UC67-13 × Chico; crossed 1995; selected 2003; tested as UC95-011-16, introd. 2012. USPP applied for. Nut: 14.7g; smooth, oval; seals strong; 55\% kernel; suitable for use in-shell; kernel: $8.0 \mathrm{~g}$; easily removed in halves; high proportion of extra-light color. Tree: vigor moderate; upright; bears on terminals and laterals; precocious; protandrous; yield high; harvest date mid-early, similar to Vina and 2 weeks before Chandler.

\section{PLUM}

\section{Ksenija Gasic and Breanna Burkes, SAFES, Clemson University, Clemson, SC}

Autumn Fantasy. Yellow-fleshed, clingstone interspecific plum. Origin: Modesto CA by G.N. Zaiger, L.M. Gardner and G.G. Zaiger. 329LN1 × 29Z574; USPP 24,041; 13 Apr. 2012. Fruit: medium to large; globose to slightly elongate; firm and meaty; moderate aroma; dark red skin; very sweet; ripens 10-20 Oct. in Modesto Stanislaus county, CA. Tree: large; vigorous; upright; productive; medium 
density; hardy; flowers medium; self-sterile; 850 chill hours; leaf glands globose.

Bella Kat. Red-fleshed, clingstone interspecific plum. Origin: Modesto CA by G.N. Zaiger, L.M. Gardner and G.G. Zaiger. 179LM244 × Royal Lee; USPP 24,040; 19 Mar. 2012. Fruit: medium to large; globose to slightly elongated; firm and meaty; slight aroma; good eating quality and flavor; moderately juicy; sweet; ripens 25 July-2 Aug. in Modesto Stanislaus County, CA. Tree: large; vigorous; upright; productive; medium density; hardy; flowers medium to large; self-sterile; 600 chill hours; leaf glands globose.

Bella Zee. Yellow-fleshed, clingstone interspecific plum. Origin: Modesto CA by G.N. Zaiger, L.M. Gardner and G.G. Zaiger; 257 LK9 $\times$ Dapple Fire; USPP 24,138; 25 Apr. 2012. Fruit: medium to large; globose to slightly elongated; firm and meaty; slight aroma; dark red skin; very sweet; ripens 4-13 Sept. in Modesto, Stanislaus County, CA. Tree: large; vigorous; semi-spreading; hardy; medium dense; flowers medium, self-sterile; 1000 chill hours; leaf glands globose.

Black Majesty IV. Yellow-fleshed, clingstone interspecific plum. Origin: Le Grand, CA by L. G. Bradford. Yummy.RTM Gem $\times$ unknown; USPP 23,739; 8 Dec. 2011. Fruit: large; uniform; blackish red skin; globose; firm and meaty; moderate juice; sweet; slight aroma; ripens 23 July-8 Aug. in San Joaquin Valley, CA. Tree: medium; medium vigor; spreading and dense; hardy; leaf glands globose.

Blackred IX. Red-fleshed, clingstone interspecific plum. Origin: Le Grand, CA by L.G. Bradford. 19P442 × unknown; USPP 23,694; 8 Dec. 2011. Fruit: large; uniform, globose, symmetrical; very dark red skin; very juicy; firm, crisp, melting; acid and sweet; very slight aroma; ripens 29 Aug.-14 Sept. in San Joaquin Valley. Tree: medium; vigorous; upright and open; hardy; productive; leaf glands globose.

Blackred VI. Red-fleshed, clingstone interspecific plum. Origin: Le Grand, CA by L. G. Bradford. 19P442 × unknown; USPP 23,718; 8 Dec. 2011. Fruit: medium to large; uniform, oblate, symmetrical; very dark red skin; moderate juice; firm, tough, crisp; acidity and sweet; slight aroma; ripens 27 June-10 July in San Joaquin Valley. Tree: medium; vigorous; upright and dense; hardy; productive; leaf glands globose.

Ebony Rose. Red-fleshed, clingstone interspecific plum. Origin: Modesto, CA by G.N. Zaiger, L.M. Gardner and G.G. Zaiger. Crimson Kat $\times 168$ LM497; USPP 24,055; 13 Apr. 2012. Fruit: medium to large; globose to slightly oblate; firm and meaty; moderate aroma; solid dark red skin; sweet and very juice; ripens 13-20 July in Modesto, Stanislaus County, CA. Tree: large; vigorous; upright; productive; regular bearer; medium density; hardy; flowers medium; self-sterile; 600 chill hours; leaf glands globose.

Festival Red. Red-fleshed, clingstone interspecific plum. Origin: Modesto CA by G.N. Zaiger, L.M. Gardner and G.G. Zaiger. 288LF477 × Flavor Treat; USPP 23,778; 12 Dec. 2011. Fruit: dark red skin; large; globose; firm and meaty; slight aroma; juicy and sweet; ripens 27 Jun-7 Jul in Modesto, Stanislaus County, CA. Tree: large; vigorous; upright; medium density; hardy; flowers small to medium; self-sterile; 600 chill hours; leaf glands globose.

Flavor Blast. Yellow-fleshed, clingstone interspecific plum. Origin: Modesto CA by G.N. Zaiger, L.M. Gardner and G.G. Zaiger. USPP 23,720; 12 Dec. 2011. Fruit: medium; globose to slightly elongated; very firm; crisp, meaty; moderate aroma; acid and sweet; ripens $23-$ 31 Aug. in Modesto, Stanislaus County, CA. Tree: large; vigorous; upright; medium density; hardy; flowers medium; self-sterile; 700 chill hours; leaf glands globose.
Glory Red. Red-fleshed, free-stone plum. Origin: Bakersfield, CA by D.W. Cain, T. A. Bacon. 93P-007 × 90P-055; USPP 23,780; 10 Nov. 2011. Fruit: medium; black skin; round; medium firmness; mildly tart; medium-high acidity; very sweet; juicy; slight aroma; ripens 28 July-7 Aug. in Wasco, Kern County, CA. Tree: medium; moderately vigorous; semi-upright; medium density; hardy; flowers medium; 600 chill hours; leaf glands globose.

Greensweet XX. Yellow-fleshed, clingstone interspecific plum. Origin: Le Grand, CA by L. G. Bradford. September Yummy.RTM $\times$ unknown; USPP 23,738; 8 Dec. 2011. Fruit: small to medium; green and red skin; globose; firm, crisp, meaty; sweet with moderate acid; very slight aroma; ripens 23 Oct.-6 Nov. in San Joaquin Valley, CA. Tree: medium; vigorous; upright and dense; hardy; leaf glands globose.

Greensweet XXI. Yellow-fleshed, clingstone interspecific plum. Origin: Le Grand, CA by L.G. Bradford. September Yummy.RTM $\times$ unknown; USPP 23,693; 8 Dec. 2011. Fruit: small to medium; uniform, globose; deep red skin; very juice; firm, tough, meaty; very sweet with moderate acid; very slight aroma; ripens 2-16 Nov. in San Joaquin Valley, CA. Tree: medium; medium vigor; upright and dense; hardy; productive; leaf glands globose.

Latesweet XX. Yellow-fleshed, semi-clingstone interspecific plum. Origin: Le Grand, CA by L.G. Bradford. September Yummy.RTM $\times$ unknown; USPP 23,740; 8 Dec. 2011. Fruit: medium; uniform, oblate; very dark red; moderately juice; firm, crisp, meaty; sweet with moderate acid; very slight aroma; ripens 23 Oct. -6 Nov. in San Joaquin Valley, CA. Tree: medium; vigorous; upright and dense; hardy; leaf glands globose.

Latesweet XXI. Yellow-fleshed, clingstone interspecific plum. Origin: Le Grand, CA by L.G. Bradford; September Yummy.RTM $\times$ unknown; USPP 23,779; 8 Dec. 2011. Fruit: juicy; firm; full red to purple skin; small to medium; globose to slightly oblong; moderately juicy; firm, crisp, meaty; sweet with slight acid; very slight aroma; ripens 2-16 Nov. in San Joaquin Valley, CA. Tree: small; medium vigor; upright and dense; hardy; leaf glands globose.

Plumcandy X. Yellow-fleshed, clingstone interspecific plum. Origin: Modesto CA by G.N. Zaiger, L.M. Gardner and G.G. Zaiger. 162LM354 × 21ZA1058; USPP 23,211; 10 Jan 2011. Fruit: small to medium; globose; firm, meaty; very slight aroma; acid and sweet; yellow-red skin; ripens 27 June-5 July in Modesto, Stanislaus County, CA. Tree: large; vigorous; upright; productive; medium density; hardy; flowers small to medium; self-sterile; 900 chill hours; leaf glands globose.

Plumred IX. Red-fleshed, clingstone interspecific plum. Origin: Le Grand, CA by L.G. Bradford. September Yummy.RTM $\times$ unknown; USPP 23,719; 8 Dec. 2011. Fruit: medium; full red skin; globose to oblate; firm; acid and sweet; moderate aroma; ripens 29 Aug.-23 Sept. in San Joaquin Valley, CA. Tree: medium; moderately vigorous; upright and dense; hardy; productive; leaf glands globose.

Plumred VII. Red-fleshed, clingstone interspecific plum. Origin: Le Grand, CA by L.G. Bradford. 26P166 × unknown; USPP 23,686; 8 Dec. 2011. Fruit: medium; uniform, globose; dark red skin; very juicy; firm, crisp; acid and sweet; slight aroma; ripens 25 July-10 Aug. in San Joaquin Valley, CA. Tree: medium; moderately vigorous; spreading and dense; hardy; productive; leaf glands globose.

Plumred VIII. Red-fleshed, clingstone interspecific plum. Origin: Le Grand, CA by L.G. Bradford. 19P442 × unknown; USPP 23,741; 8 Dec. 2011. Fruit: medium to large; deep red skin; globose; firm and crisp; juicy; slight aroma; ripens 19 Aug.-2 Sept. in San Joaquin Valley, CA. Tree: medium; vigorous; upright and dense; hardy; leaf glands globose. 
Plumsweet XIV. Red-fleshed, clingstone interspecific plum. Origin: Modesto CA by G.N. Zaiger, L.M. Gardner and G.G. Zaiger. 30M591 × 160LM295; USPP 23,668; 1 Dec. 2011. Fruit: large; globose; firm, meaty; moderate aroma; acid and sweet; very juicy; dark red skin; ripens 4-12 Sept. in Modesto, Stanislaus County, CA. Tree: large; upright; productive; vigorous; hardy; flowers medium; self-sterile; 750 chill hours; leaf glands globose.

Plumsweet XV. Yellow-fleshed, semi-clingstone interspecific plum. Origin: Le Grand, CA by L.G. Bradford. 39P898 × unknown; USPP 23,685; 8 Dec. 2011. Fruit: medium; uniform, globose; very red skin; moderately juicy; firm, tough, meaty; hint of coconut; very slight aroma; ripens 8-22 Sept. in San Joaquin Valley, CA. Tree: large; medium vigor; spreading; hardy; production; leaf glands globose.

Suplumfortyfour. Yellow-fleshed, semi-freestone plum. Origin: Bakersfield, CA by D.W. Cain, T.A. Bacon. 91P-045 × 92P-033; USPP 23,722; 10 Nov. 2011. Fruit: large; round; light yellow-green skin; mildly tart; juicy; slight aroma; ripens 20-23 June in Wasco, Kern County, CA. Tree: medium; moderately vigorous; semi-upright; medium density; hardy; flowers medium; leaf glands globose.

Sweet Pixzee 2. Yellow-fleshed, clingstone interspecific plum. Origin: Modesto CA by G.N. Zaiger, L.M. Gardner and G.G. Zaiger. 178LM74 × 5ZA500; USPP 23,796; 12 Dec. 2011. Fruit: medium; slightly elongated to globose; firm and meaty; slight aroma; very juicy; red skin; sweet; ripens 24 June-2 July in Modesto, Stanislaus County, CA. Tree: large; vigorous; upright; medium density; hardy; flowers medium; self-sterile; 850 chill hours; leaf glands globose.

\section{PLUM ROOTSTOCK}

Thomas G. Beckman, USDA-ARS Southeastern Fruit and Tree Nut Res. Lab., Byron, GA

Densipac. Compatible with Japanese plum varieties. Described under Peach Rootstock.

HBOK 27. Compatible with Japanese plum varieties. Described under Peach Rootstock.

\section{POMEGRANATE}

\section{John M. Chater, Department of Botany and Plant Sciences, University of California, Riverside, Riverside, CA}

Blaze. Medium-sized, tart, shiny, bright red pomegranate. Origin: Camarillo, CA, by S.J. Chater in the 1980s. Parentage unknown. Fruit: midsized, round, variable, weighs up to $850 \mathrm{~g}$; exocarp shiny, smooth, leathery;color bright red;calyx medium-sized, delicate, proportional, typically open, with triangular lobes that bend outward; ripens up to November in Riverside, CA; arils red to dark red, turning to blackish red at maturity (color development may depend on climate), medium to large, juicy; seed hardness moderate; eaten fresh, has a tart to sweet-tart, astringent flavor with slight grenadine syrup undertone; juice red to blackish red, pulpy, syrupy, sweet-tart to tart with grenadine character; useful for fresh market, juice, syrup, jellies and cocktails. Tree: leaves average size, showy flowers, productive, vigorous upright branching with willowing and branching characteristic of pomegranate; readily propagated by hardwood cuttings.

Golden Globe. Very large, honey-sweet, golden-yellow pomegranate. Origin: Camarillo, CA, by S.J. Chater in the 1980s. Parentage unknown. Fruit: very large, round, weighing up to 900 g; exocarp thick and smooth; color predominately golden-yellow with pinkish and/or reddish blushing; calyx medium-sized, typically open, with triangular lobes that tend to bend outward;ripens September to November in Riverside, CA, earlier than Green Globe;arils pink, large, with moderately hard seeds, eaten fresh, has a very sweet, lowacid honey and apple flavor; juice pink, very sweet, low-acid with striking honey character; useful for fresh market, better for juice. Tree: very large leaves, with blade up to $9 \mathrm{~cm}$ in length, vigorous upright branching with willowing characteristic; readily propagated by hardwood cuttings.

Green Globe. Large, sweet, green-skinned pomegranate. Origin: Camarillo, CA, by S.J. Chater in the 1980s. Parentage unknown. Fruit: large, elegantly rotund, weighs up to $850 \mathrm{~g}$; exocarp thick, waxy, leathery and smooth; color starts out green and turns goldenyellow at maturity, may display pink to pinkish red hues and green color at maturity; calyx large, typically open at maturity, durable and thick, with triangular, pointy lobes that stand upright and are crownlike; arils medium-sized, plump, ruby to pinkish red, juicy with midsized, moderately hard, crunchy seeds; ripens from September to November in Riverside, CA, prone to late-season split; . eaten fresh, has a sweet, low-acid flavor; juice bright pinkish red, very sweet with low acidity; useful for fresh market or juice. Tree: very large leaves, with blades up to $9 \mathrm{~cm}$ long, vigorous upright branching with partial willowing and creeping characteristics;difficult to propagate by hardwood cuttings.

Phoenicia. Large semi-tart multipurpose pomegranate. Origin: Camarillo, CA, by S.J. Chater in the 1980s. Parentage unknown. Fruit: large, round and uniform, diameter measuring up to $12.7 \mathrm{~cm}$; leathery exocarp very rigid;color highly variable mottled red and green, may contain pinkish hues; calyx large, durable and thick, with pentagonal, triangular-tipped lobes that stand upright like a crown;arils large, florescent pinkish-rubine red to pinkish red, fleshy with midsized, fully developed, moderately hard yet edible seeds;ripens mid to late October in Riverside, CA; prone to late-season splitting, depending on climate; . eaten fresh, has a piercing sweet- to semi-tart flavor;juice bright pinkish red, sweet-tart;useful for fresh market or for value-added products including juices, jellies, grenadine syrups and cocktail mixers, although may be too tart for some fresh market consumers;arils and fruit keep well in refrigerated storage. Tree: large leaves, vigorous upright branching;not as easily propagated as other pomegranate cultivars by hardwood cuttings.

Rosamia. Scarlet, sweet, soft-seeded pomegranate. Origin: Camarillo, CA, by S.J. Chater in the 1980s.Parentage unknown; named after breeder's wife, R.E. Chater. Fruit: similar to Eversweet, but larger and scarlet in color, not pink; produces only one determinant crop per season, which is different than the indeterminate nature of Eversweet; soft exocarp with medium to thick rind, pink to scarlet red; calyx same as Eversweet, pointing inward, durable and thick, with triangulartipped lobes; arils medium, pink to pinkish red, juicy with soft seeds; ripens late August to September in Riverside, CA, depending on season and climate eaten fresh, has a sweet, fuller flavor than 'Eversweet,' with similarly soft seeds; juice pink to reddish pink, sweet and delicate; useful for fresh market, has potential for wine-making. Tree: size medium, larger, more vigorous and productive than Eversweet; growth pattern willowy and creepy with tendency to sucker; propagation success by hardwood cuttings unknown; one crop per year.

\section{RASPBERRY}

Patrick P. Moore, Horticulture and Landscape Architecture Department, Washington State University, Puyallup, WA

Chaim Kempler. Agriculture and Agri-Food Canada, Pacific Agri-Food Research Center, Agassiz, BC, Canada

Cascade Harvest. Mid-season, floricane fruiting red raspberry for fresh or processed markets. Origin: Washington State University, by P.P. Moore and W. Hoashi-Erhardt. Cascade Dawn $\times$ WSU 1145; crossed 1998; selected 2001; tested as WSU 1507; introd. 2014. USPP applied for. Fruit: large; long conical; medium red; ripens 2-6 days before Meeker; easily removed from receptacle; well suited to 
machine harvest. Plant: upright canes; moderate sucker production; resistant to Raspberry bushy dwarf virus (RBDV); tolerant of root rot (Phytophthora rubi).

Crimson Night. Late season, primocane fruiting red raspberry for fresh or processing suitable for cool climate production. Origin: New York State Agricultural Experiment Station-Geneva, Cornell University, Ithaca, NY, by C.A. Weber. NY270 $\times$ NY357; crossed 1999; selected 2003; tested as NY03-56; introd. 2012. USPP applied for. Fruit: large; wide conical; firm; dark shiny red; high flavor with low acidity; ripens with Heritage; detaches easily from receptacle; good shelf-life. Plant: sturdy upright canes; moderate sucker production; highly pigmented red/purple primocanes; fruit produced on upper $2 / 3$ of canes.

Double Gold. Late season, primocane fruiting amber/blush raspberry for fresh market cool climate production. Origin: New York State Agricultural Experiment Station-Geneva, Cornell University, Ithaca, NY, by C.A. Weber. NY319 $\times$ Graton Gold (Goldie); crossed 1999; selected 2004; tested as NY04-25; introd. 2012. USPP applied for. Fruit: medium; conical; moderately soft; highly blushed amber; pink when frozen; very high flavor; ripens 2 weeks after Heritage; detaches easily from receptacle. Plant: medium diameter, upright, very tall canes; high sucker production; little cane pigmentation; primocane fruit produced on upper $1 / 3$ of canes; tall canes suitable for double cropping systems.

Niwot. Double-cropping black raspberry, fruiting well on both floricanes and primocanes; suitable for backyard growers, farmers markets, and PYO. Origin: Longmont, CO by P. Tallman. Third generation derivative of 1998 cross of PT-CB $\times$ PT-W1.7; selected 2006; tested as PT-2A4; introd. 2014; USPP applied for. Fruit: appearance and flavor similar to Jewel, black, $2 \mathrm{~g}$; floricane berries start ripening one week before Jewel; primocane berries $3 \mathrm{~g}$, start ripening late August or early September continuing until first frost. Plant: very vigorous; more hardy than Jewel in USDA hardiness zone 5; suitable for USDA hardiness zones 5 to 7.

NR7 (Raspberry ShortCake ${ }^{\mathrm{TM}}$ ). Dwarf floricane fruiting red raspberry particularly suited to home gardens. Origin: Plant and Food Research Limited, Motueka, New Zealand by M.J. Stephens and H.K. Hall. HR101 × Willamette; crossed 1997; selected 2001; tested as NR7; introd. 2012. USPP 22,141, 13 Sept. 2011. Fruit: medium (3-5 g); dull red; ovate-round; mid-season ripening, mild flavor, easily removed from receptacle; recommended for fresh consumption. Plant: dwarfing canes, very short internodes $(10-20 \mathrm{~mm})$, canes commonly only achieve 500-600 mm height, many completely spineless canes; ornamental plant particularly suitable to home gardens and containerized patio planting, resistant to RBDV.

Raspberry ShortCake ${ }^{\mathrm{TM}}$. See NR7.

\section{STRAWBERRY}

\section{Kim S. Lewers, USDA-ARS, Genetic Improvement of Fruits} and Vegetables Laboratory, Beltsville, MD

Barak. Short-day strawberry adapted to winter production in Israel's Sharon Coastal Plain. Origin: State of Israel, Ministry of Agriculture and Rural Development, Agricultural Research Organization, Bet Dagan, Israel, by N. Dai, Z. Tanami, S. Slotzky, A. Daos. Tamir $\times$ ARO 730, crossed 2004; selected in Bet-Dagan, Israel, greenhouse, 2006; USPP 22,633, 10 Apr. 2012. Fruit: glossy dark red (RHS 45A; mid-sized, 19-24 g; uniform conic; firm, red (RHS 45C) flesh, sweet, low acidity; large reflexed surface calyx; surface achenes; early season. Plant: moderate to strong vigor, many stolons; moderate yield, 744-746 g/plant; globose, medium density; flowers above foliage, prostrate fruiting trusses; moderately tolerant to Botrytis fruit rot (Botrytis cinerea), powdery mildew (Sphaerotheca macularis).
Benicia. Short-day strawberry adapted to arid sub-tropical climates. Origin: The University of California, by D.V. Shaw, K.D. Larson. Palomar $\times$ Cal 0.18-601, crossed 2004; selected in Winters, CA, 2005; tested as Cal 4.39-1 and C225; USPP 22,542, 6 Mar. 2012. Fruit: red (Munsell 2.5 R 7/10); very large, $33.7 \mathrm{~g}$; variable, medium to long conic, slight neck; very firm, orange-red (Munsell 7.5 R 5/13) flesh, outstanding flavor; inset-surface calyx equal to or larger than fruit; surface-inset achenes; season later than Ventana and Palomar, earlier than Camarosa. Plant: moderate vigor, medium stolon number, 28 daughter plants; very high yield 2,566 g/plant; flowers at or above canopy, fruiting trusses; moderately resistant to powdery mildew; tolerant to two-spotted spider mite (Tetranychus urticae), local strawberry viruses; moderately susceptible to anthracnose crown rot (Colletotrichum acutatum), Phytophthora crown rot (Phytophthora cactorum), common leaf spot (Ramularia tulasnei); very susceptible to Verticillium wilt (Verticillium dahliae).

Bob. Dayneutral strawberry adapted to coastal central California. Origin: Sweet Darling Sales, Inc., Aptos, CA, by J. Larse. $1501 \times$ 1242; selected in Watsonville, CA; tested as 105626; USPP 23,935, 1 Oct. 2013. Fruit: red (RHS 45A); mid-sized to large, $20.7 \mathrm{~g}$; variable, conic, cylindrical, wedge-shaped; firm, orange-red (RHS 41B) and white (RHS 155C) flesh, balanced flavor; mid-sized clasping to reflexed surface calyx; surface achenes; early season. Plant: vigorous, few stolons, 1 daughter plant; low yield, 153.4 g/plant; globose, medium density; flowers at canopy, prostrate fruiting trusses; susceptible to bruising, rain.

Capri. Fully remontant strawberry adapted to European continental climates. Origin: Consorzio Italiano Vivaisti-Societa Consortile A R.L., Ferrara, Italy, by M. Leis, A. Martinelli, G. Castagnoli. CIVRI-30 × R6R1-26; selected in San Giuseppe di Comacchio, Ferrara, Italy, 2005; USPP 23,339, 22 Jan. 2013. Fruit: glossy red (RHS 46A); large, 20g-33 g; moderately uniform conic; firm, orange red (RHS 33A, RHS 35A) and white (RHS 155D) flesh, very good flavor (7.5-8.5 ${ }^{\circ}$ Brix); mid-sized spreading surface calyx; surface achenes; long season, June-Nov. Plant: medium to strong vigor, medium stolon number, 7-9/plant; high yield, 1,000-1,200 g/plant; semi-upright, medium density; flowers at canopy, semi-erect fruiting trusses; resistant to local fungal diseases, tolerant to mildew, moderately susceptible to leaf spot.

Cupcake. Dayneutral strawberry adapted to coastal central California. Origin: Sweet Darling Sales, Inc., Aptos, CA, by J. Larse.102213 × 1581; selected in Watsonville, CA; tested as 107615; USPP 23,956, 8 Oct. 2013. Fruit: glossy light red (RHS 45A); mid-sized to large, $31.5 \mathrm{~g}$; variable, conic, cylindrical5, wedge-shaped; firm to very firm, orange-red (RHS 41B) and white (RHS155C) flesh, balanced flavor; mid-sized spreading surface calyx; surface achenes; early season. Plant: vigorous, few stolons, 1 daughter plant; very low yield, $105.1 \mathrm{~g} / \mathrm{plant}$; globose, upright, medium density; flowers at canopy, prostrate fruiting trusses; resistant to bruising, rain.

Dely. Short-day strawberry adapted to European continental climates. Origin: Consorzio Italiano Vivaisti-Societa Consortile A R.L., Ferrara, Italy, by M. Leis, A. Martinelli, G. Castagnoli. T2-6 $\times$ A20-17; selected in San Giuseppe di Comacchio, Ferrara, Italy, 2004; USPP 23,127, 23 Oct. 2012. Fruit: glossy red (RHS 45A); medium to large; moderately uniform conic; moderately firm, red (RHS 44A), orange-red (RHS 39) and white (RHS 155D) flesh, very good flavor ( $\sim 9{ }^{\circ}$ Brix $)$; mid-sized spreading surface calyx; surface achenes; early season. Plant: vigorous, medium to high stolon number, 10-15/plant; moderate yield, $600 \mathrm{~g} /$ plant; globose, semi-upright, medium density; flowers at canopy, semi-erect fruiting trusses; resistant to local leaf and root diseases.

DrisStrawEighteen. Fully everbearing strawberry adapted to coastal southern California. Origin: Driscoll Strawberry Associates, Inc., Watsonville, CA, by M.D. Ferguson, T.C. Moran. 91J302 × 26H165, crossed 2004; selected in Shasta County, CA, 2005; USPP 
23,107, 16 Oct. 2012. Fruit: dark red (RHS 46B); mid-sized, 27.2 g; uniform conic; firm, medium red-orange (RHS RHS N34B) and white (RHS 155C) flesh, sweet, moderate acidity, fine texture; large spreading to reflexed surface calyx; surface achenes; early season. Plant: moderate vigor, 3 crowns/plant, few stolons, 12 daughter plants; low yield, $335.2 \mathrm{~g} /$ plant; globose, semi-upright, medium density; flowers below foliage, prostrate fruiting trusses; moderately resistant to wind, high $\mathrm{pH}$; moderately susceptible to powdery mildew, leather rot (Phytophthora cactorum), common leaf spot, leaf scorch (Diplocarpon earlianum), leaf blight (Phomopsis obscurans), black root rot disease complex (Rhizoctonia fragariae, Coniothyrium fuckelii, Hainesia lythri, Idriella lunata, Pyrenochaeta sp., Pythium spp.), angular leaf spot (Xanthomonas fragariae), two-spotted spider mite, cyclamen mite (Tarsonemus pallidus), strawberry foliar nematode (Aphelencoides fragariae), root lesion nematode (Pratylenchus penetrans), stem eelworm (Ditylenchus dipsac), strawberry blossom weevil (Anthonomus rubi), aphids (Aphis spp.), high temperatures, water logging; susceptible to Botrytis fruit rot, Verticillium wilt, red stele (Phytophthora fragariae), Lygus bug (Lygus hesperus), drought, high soil salt levels.

DrisStrawNineteen. Dayneutral strawberry adapted to Florida. Origin: Driscoll Strawberry Associates, Inc., Watsonville, CA, by K.L. Gilford, J.R. Alcazar, B.D. Mowrey, P.J. Stewart. Driscoll Atlantis $\times 43 \mathrm{~J} 313$, crossed 2004; selected in Shasta County, CA, 2005; USPP 23,148, 30 Oct. 2012. Fruit: dark red (RHS 46A); midsized, $25.3 \mathrm{~g}$; moderately uniform conic to bi-conic; firm, medium red (RHS 41B) and white (RHS 155B) flesh, moderately sweet, low acidity, medium texture; large raised clasping to reflexed calyx; raised achenes; very early season. Plant: moderate vigor, 3 crowns/ plant, many stolons, 78 daughter plants; low yield, $210 \mathrm{~g} / \mathrm{plant}$; flat globose, medium density; flowers below foliage, prostrate fruiting trusses; moderately resistant to Botrytis fruit rot, powdery mildew, angular leaf spot, two-spotted spider mite; highly susceptible to Lygus bug.

DrisStrawTwenty. Short-day strawberry adapted to coastal southern California. Origin: Driscoll Strawberry Associates, Inc., Watsonville, CA, by M.D. Ferguson, J.R. Alcazar. 2K297 × Driscoll Ojai, crossed 2005; selected in Shasta County, CA, 2005; USPP 23,383, 12 Feb. 2013. Fruit: glossy red (RHS 46A); large, $25.8 \mathrm{~g}$; uniform conic; firm, red (RHS 44B, RHS 2B) and white (RHS 155B) flesh, moderately sweet, low acidity, medium texture; large raised reflexed calyx; surface achenes; late season. Plant: vigorous, 3 crowns/plant, many stolons, 28 daughter plants; moderate yield, $544 \mathrm{~g} /$ plant; globose, semi-upright, medium density; flowers above foliage, erect fruiting trusses; resistant to powdery mildew, angular leaf spot, moderately resistant to two-spotted spider mite.

DrisStrawTwentyTwo. Fully everbearing strawberry adapted to coastal southern California. Origin: Driscoll Strawberry Associates, Inc., Watsonville, CA, by M.D. Ferguson, T.C. Moran. DrisStrawThree $\times$ 50L206, crossed 2006; selected in Shasta County, CA, 2007; USPP 23,517, 9 Apr. 2013. Fruit: dark red (RHS 46A); mid-sized, $30.6 \mathrm{~g}$; uniform conic to cylindrical; firm, red (RHS 46A, RHS 43A) and white (RHS 155D, RHS N155B) flesh, balanced flavor, coarse texture; mid-sized reflexed surface calyx; surface achenes; midseason. Plant: moderate vigor, 3 crowns/plant, few stolons, 45 daughter plants; low yield, 285.1 g/plant; globose, semi-upright, dense; flowers below foliage, prostrate fruiting trusses.

DrisStrawTwentyEight. Partially everbearing strawberry adapted to coastal central California. Origin: Driscoll Strawberry Associates, Inc., Watsonville, CA, by P.J. Stewart, J.F. Coss, M.P. Madesko, B.D. Mowrey. 95L299 × 251M27; selected in Monterey County, CA, 2007; USPP 23,459, 12 Mar. 2013. Fruit: dark red (RHS 46A); mid-sized, $21.1 \mathrm{~g}$; uniform conic; firm red (RHS 43B, RHS 43D, RHS 49B) and white (155B) flesh, tart, moderate sweetness, medium texture; midsized, reflexed surface calyx; raised achenes; mid-season. Plant: vigorous, 3 crowns/plant, medium stolon number, 49 daughter plants; high yield, 1,218 g/plant; flat, globose, medium density; flowers at canopy, prostrate fruiting trusses; resistant to moderately resistant to Botrytis fruit rot; moderately susceptible to powdery mildew, Verticillium wilt, high temperatures; moderately susceptible to susceptible to wind.

DrisStrawTwentyFive. Short-day strawberry adapted to coastal southern California. Origin: Driscoll Strawberry Associates, Inc., Watsonville, CA, by M.D. Ferguson, T.C. Moran. 18L33 × 192M122; selected in Ventura County, CA, 2007; USPP 23,382, 12 Feb. 2013. Fruit: dark red (RHS 46B); very large, 33.6 g; moderately uniform conic; firm, red-orange (RHS 33B) and white (RHS 155D) flesh, sweet, medium acidity and texture; mid-sized reflexed surface calyx; surface achenes; early season. Plant: moderate vigor, 3 crowns/plant, many stolons, 59 daughter plants; high yield, 1,208 g/plant; flat, globose, medium density; flowers above foliage, prostrate fruiting trusses; moderately resistant to Verticillium wilt, angular leaf spot, wind, high $\mathrm{pH}$, high soil salt levels; moderately susceptible to high temperatures; susceptible to Botrytis fruit rot, powdery mildew, aphids, Lygus bug.

DrisStrawTwentyFour. Partially everbearing strawberry adapted to Florida. Origin: Driscoll Strawberry Associates, Inc., Watsonville, CA, by E.J. Pullen, P.J. Stewart, K.L. Gilford, B.D. Mowrey. 3M44× 50L174; selected in Hillsborough County, FL, 2007; USPP 23,378, 5 Feb. 2013. Fruit: glossy dark red (RHS 46B); very large, 28.4 g; moderately uniform conic; firm, red (RHS 44A, RHS 39B) and white (RHS 155B) flesh, balanced flavor, coarse texture; mid-sized raised clasping to reflexed calyx; raised achenes; very early season. Plant: moderate vigor, 3 crowns/plant, medium stolon number, 73 daughter plants; moderate yield, $682 \mathrm{~g} /$ plant; flat, spreading, open, sparse to medium density; flowers below foliage, prostrate fruiting trusses; moderately resistant to high temperatures, high $\mathrm{pH}$, cool weather/ freezes; susceptible to Botrytis fruit rot, powdery mildew, Verticillium wilt, angular leaf spot.

DrisStrawTwentyOne. Fully everbearing strawberry adapted to Florida. Origin: Driscoll Strawberry Associates, Inc., Watsonville, CA, by M.D. Ferguson, T.C. Moran. $13 \mathrm{H} 377 \times 587 \mathrm{~L} 48$, crossed 2007; selected in Shasta County, CA, 2008; USPP 23,506, 2 Apr. 2013. Fruit: dark red (RHS 46A); large, 30.8 g; moderately uniform bi-conic; moderately firm, red (RHS 44B, RHS 41B) and white (RHS 155B) flesh, mild flavor, medium texture; large inset reflexed calyx; surface achenes; late season. Plant: vigorous, 4 crowns/plant, few stolons, 28 daughter plants; moderate yield, $487 \mathrm{~g} / \mathrm{plant}$; upright, dense; flowers below foliage, prostrate fruiting trusses.

DrisStrawTwentySeven. Short-day strawberry adapted to coastal southern California. Origin: Driscoll Strawberry Associates, Inc., Watsonville, CA, by M.D. Ferguson, T.C. Moran. DrisStrawEight $\times$ 10L297; selected in Ventura County, CA, 2007; USPP 23,400, 19 Feb. 2013. Fruit: glossy dark red (RHS 46A); very large, 30.3 g; moderately uniform conic; firm red (RHS 40C) and white (155D) flesh, sweet, low acidity, coarse texture; mid-sized raised reflexed calyx; surface achenes; very early season. Plant: moderate vigor, 3 crowns/ plant, many stolons, 108 daughter plants; high yield, 1,063 g/plant; flat, globose, medium density; flowers above foliage, prostrate fruiting trusses; moderately resistant to Verticillium wilt, wind, high temperatures, high $\mathrm{pH}$, high soil salt levels, water logging; moderately susceptible to powdery mildew, common leaf spot, angular leaf spot, aphids; susceptible to Botrytis fruit rot, Lygus bug.

DrisStrawTwentySix. Short-day strawberry adapted to coastal southern California. Origin: Driscoll Strawberry Associates, Inc., Watsonville, CA, by M.D. Ferguson, T.C. Moran. 18L33 × 193M68; selected in Ventura County, CA, 2007; USPP 23,377, 5 Feb. 2013. Fruit: dark red (RHS 46A); large, $30 \mathrm{~g}$; moderately uniform conic; moderately firm, light red (RHS 39B) and white (RHS 155A) flesh, balanced flavor, medium texture; mid-sized, reflexed surface calyx; surface achenes; very early season. Plant: moderate 
vigor, 3 crowns/plant, medium stolon number, 82 daughter plants; very low yield, $94.3 \mathrm{~g} / \mathrm{plant}$; flat, globose, medium density; flowers above foliage, prostrate fruiting trusses; moderately resistant to high $\mathrm{pH}$, high soil salt levels; moderately susceptible to powdery mildew, angular leaf spot, high temperatures, wind; susceptible to Botrytis fruit rot, Verticillium wilt, aphids, Lygus bug.

DrisStrawTwentyThree. Short-day strawberry adapted to Florida. Origin: Driscoll Strawberry Associates, Inc., Watsonville, CA, by E.J. Pullen, P.J. Stewart, K.L. Gilford, B.D. Mowrey. 1M16 × 87K286; selected in Hillsborough County, FL, 2007; USPP 23,401, 19 Feb. 2013. Fruit: dark red-orange (RHS N34A); very large, 29.2 g; uniform bi-conic; moderately firm, red (RHS 42B, RHS 39A) and white (RHS 155B, RHS 155D) flesh, balanced flavor, coarse texture; very small, raised, clasping to reflexed calyx; raised achenes; early season. Plant: medium to strong vigor, 3 crowns/plant, very few stolons, 68 daughters/plant; moderate yield, $616.3 \mathrm{~g} /$ plant; upright center, flat perimeter, dense center, sparse perimeter; flowers below foliage, prostrate fruiting trusses; moderately resistant to high temperatures, low acid; moderately susceptible to Botrytis fruit rot, powdery mildew, Verticillium wilt; susceptible to angular leaf spot, cold temperatures.

FL 05-107. Short-day strawberry adapted to Florida. Origin: University of Florida, by C.K. Chandler. Florida Radiance $\times$ Earlibrite; selected in Balm, FL, winter 2005-2006; USPP 23,042, 18 Sept. 2012. Fruit: glossy bright red (RHS 34B); mid-sized 30-40 g primaries, 10-30 g secondaries and tertiaries; uniform conic; very firm, light orange (RHS 32C) flesh, sweet, low acidity; medium to large attractive calyx; surface achenes; early season. Plant: moderate to high yield, 453-1,060 g/plant; flowers at or below canopy; resistant to abrasion, anthracnose fruit rot (C. acutatum).

Flair. Short-day strawberry adapted to The Netherlands. Origin: El Santa Beheer B.V., Ens, The Netherlands, by M.E. Suiker. Flevo 00-24-7 × Flevo 00-08-4, crossed 2003; selected in a controlled environment in Ens, The Netherlands, 2004; PP23,162, 6 Nov. 2012. Fruit: glossy red-orange (RHS 34A); mid-sized; conic to roundcordate; moderately firm, orange-red (RHS 33A) flesh, balanced flavor; mid-sized raised spreading calyx; surface achenes; early season. Plant: vigorous; globose, open.

Flavorfest. Short-day strawberry adapted to the Mid-Atlantic, USA. Origin: USDA-ARS, Beltsville, MD, by K.S. Lewers, J.M. Enns, S.C. Hokanson, J.L. Maas, G.J. Galletta. B759× B786, crossed 1996; selected in Beltsville, MD, 1998; tested as B1033; introduced 2013. Fruit: bright red; large/average from $49 / 25$ g to $28 / 14 \mathrm{~g}$; variable plump round-conic; firm, light red flesh, excellent flavor $\left(6.4-9.8^{\circ} \mathrm{Brix}\right.$, pH 3.3-4.0); small-medium spreading surface calyx; inset-surface achenes; long mid-season. Plant: vigorous, medium stolon number; moderate to high yield, $690 \mathrm{~g} /$ plant 9-year average (341-1,114 $\mathrm{g} / \mathrm{plant}$ ); large, upright, medium density, light at base; flowers at or below canopy, prostrate fruiting trusses, resistant to local anthracnose fruit rot, crown rot (C. accutatum, C. fragariae CF63), red stele (Race A-3, $R p f_{1}$ ); moderately resistant to field Botrytis fruit rot, leaf blight, leaf scorch; moderately susceptible to powdery mildew, red stele (Race A-5); susceptible to anthracnose crown rot (C. fragariae CG163, C. gloeosporoides CG162), postharvest Botrytis fruit rot.

Ginza. Dayneutral strawberry adapted to coastal central California. Origin: Sweet Darling Sales, Inc., Aptos, CA, by J. Larse. $1929 \times$ 1902; selected in Watsonville, CA; tested as 102011; USPP 23,934, 1 Oct. 2013. Fruit: red (RHS 45A); mid-sized, 16.8 g; variable, conic, long-conic, long-wedge; firm, orange-red (RHS 41B) and white (RHS 155C) flesh, balanced flavor; mid-sized spreading to reflexed surface calyx; raised achenes; early season. Plant: vigorous, few, 1 daughter plant; very low yield, $91.7 \mathrm{~g} /$ plant; globose, upright, obtuse at base, medium density, light at base; flowers at canopy, prostrate fruiting trusses; resistant to weather variation.
Joly. Short-day strawberry adapted to European continental climates. Origin: Consorzio Italiano Vivaisti-Societa Consortile A R.L., Ferrara, Italy, by M. Leis, A. Martinelli, G. Castagnoli. T2-6 $\times$ A20-17; selected in San Giuseppe di Comacchio, Ferrara, Italy, 2004; USPP 23,126, 23 Oct. 2013. Fruit: glossy red (RHS 45B); large; uniform conic; firm, red (RHS 44B, RHS 40B) and white (RHS $155 \mathrm{D})$ flesh, very good flavor $\left(8.5^{\circ} \mathrm{Brix}\right)$; mid-sized spreading surface calyx; surface achenes; early season. Plant: vigorous, medium to high stolon number, 12-18/plant; moderate to high yield, $800 \mathrm{~g} / \mathrm{plant}$; globose, semi-upright, medium density; flowers at canopy, semierect fruiting trusses; resistant to local leaf and root diseases.

Malwina. Short-day strawberry adapted to central European climates. Origin: P. Stoppel, Kressbronn, Germany. Unnamed seedling $\times$ Sophie, crossed 1999; selected in Kressbronn, Germany, 1999; tested as PS.01-S4; PP23,246, 11 Dec. 2012. Fruit: glossy red (RHS 45A, RHS 53A); large; conic; moderately firm flesh, very good flavor; small, raised spreading to reflexed calyx; surface achenes; very late season. Plant: vigorous; globose; flowers below foliage, fruiting trusses; resistant to rain cracking, sunburn, Verticilium wilt, local root diseases; moderately resistant to Botrytis fruit rot, powdery mildew; susceptible to flower thrips (Frankliniella spp.), common leaf spot.

Merit. Everbearing strawberry adapted to coastal central California. Origin: Plant Sciences, Inc., Watsonville, CA, by S.M. Ackerman, S.D. Nelson, M.D. Nelson. PS-2880 × PS-4630, crossed 2001; selected in Ventura County, CA, 2003; USPP 23,745, 16 July 2013. Fruit: glossy orange-red to red (RHS 34B); small, $18.1 \mathrm{~g}$; uniform conic; moderately firm, orange-red (RHS 34C) flesh, good to very good flavor $\left(8.8^{\circ}\right.$ Brix); mid-sized inset spreading calyx; surface achenes; late season. Plant: moderate vigor, few stolons, 2.4/plant; moderate yield, $503 \mathrm{~g} / \mathrm{plant}$; small globose, medium density; flowers above foliage, prostrate fruiting trusses; moderately resistant to bacterial angular leaf spot; moderately susceptible to two-spotted spider mite, flower thrips, powdery mildew, Botrytis fruit rot.

Mojave. Short-day strawberry adapted to coastal central and southern California. Origin: The University of California, Oakland, CA, by K.D. Larson, D.V. Shaw. Palomar $\times$ Cal 1.57-601, crossed 2004; selected near Irvine, CA, 2005; tested as $\mathrm{Cal}$ 4.44-603 and C227; USPP 22,589, 20 Mar. 2012. Fruit: dark red (Munsell 5 R 3/7); very large, $36.1 \mathrm{~g}$; short-medium conic; very firm, red (Munsell $5 \mathrm{R}$ 6/11) flesh, outstanding flavor; slightly inset calyx equal to or larger than fruit; inset-surface achenes; season similar to Palomar. Plant: moderate vigor, medium stolon number, 28 daughter plants; very high yield 2,271 g/plant; flowers at or above canopy, fruiting trusses; moderately resistant to powdery mildew, Verticillium wilt, common leaf spot; tolerant to two-spotted spider mite, local strawberry viruses; moderately susceptible to anthracnose crown $\operatorname{rot}($ C. acutatum); highly susceptible to Phytophthora crown rot.

Nabila. Short-day strawberry adapted to European continental climates. Origin: Consorzio Italiano Vivaisti-Societa Consortile A R.L., Ferrara, Italy, by M. Leis, A. Martinelli, G. Castagnoli. Ventana $\times$ Q6Q8-26; selected in San Giuseppe di Comacchio, Ferrara, Italy, 2004; USPP 23,338, 22 Jan. 2013. Fruit: red (RHS 45A); large; uniform conic; firm, red (RHS 41A) and orange (RHS 29A, RHS 159C) flesh, very good flavor $\left(7^{\circ}\right.$ Brix $)$; mid-sized spreading surface calyx; inset achenes; very early season. Plant: medium vigor, medium to high stolon number, 12-16/plant; moderate to high yield, 850-900 g/plant; globose, semi-upright, medium density; flowers at canopy, semi-erect fruiting trusses; resistant to local leaf and root diseases.

Planasa 02-32. Short-day strawberry adapted to protected cultivation in Spain. Origin: Plantas de Navarra, S.A, Valtierra Spain, by A. Pierron-Darbonne. 94-020 × 9719; selected in Segovia, Spain; USPP 23,903, 17 Sept. 2013. Fruit: red (RHS 44A, RHS 44B); large, 24-26 g; uniform conic; very firm $(1.35 \mathrm{Kg})$, red-orange (RHS 33A, 
RHS 33B) flesh, moderately sweet $\left(6.44{ }^{\circ}\right.$ Brix $)$; large reflexed surface calyx; surface achenes; mid-season. Plant: vigorous, medium stolon number, 7/plant; moderate to high yield, $976 \mathrm{~g} /$ plant; flat, globose, medium density; flowers at canopy, semi-erect fruiting trusses.

Rania. Short-day strawberry adapted to European continental climates. Origin: Consorzio Italiano Vivaisti-Societa Consortile A R.L., Ferrara, Italy, by M. Leis, A. Martinelli, G. Castagnoli. Ventana $\times$ Q6Q8-26; selected in San Giuseppe di Comacchio, Ferrara, Italy, 2005; USPP 23,328, 15 Jan. 2013. Fruit: red (RHS 46A-46B); very large; uniform conic; firm, orange-red (RHS 33A, RHS 35B) and white (RHS 155D) flesh, very good flavor ( $\left.8{ }^{\circ} \mathrm{Brix}\right)$; mid-sized spreading surface calyx; surface achenes; very early season. Plant: vigorous, medium to high stolon number, 12-15/ plant; high yield, 1,000 g/plant; globose, semi-upright, medium density; flowers at canopy, semi-erect fruiting trusses; resistant to local leaf and root diseases.

Sabrina. Short-day strawberry adapted to protected cultivation in Spain. Origin: Plantas de Navarra, S.A, Valtierra Spain, by A. Pierron-Darbonne. $9719 \times 94-020$; selected in Segovia, Spain; USPP 22,506, 21 Feb. 2012. Fruit: red (RHS 43A, RHS 43B); large, 24-26 g; uniform conic; firm (1.4 Kg), red (RHS 41A, RHS 41B) flesh, balanced flavor (6.9 $\left.{ }^{\circ} \mathrm{Brix}, \mathrm{pH} 3.6\right)$; small spreading surface calyx; surface achenes; mid-season. Plant: vigorous, medium stolon number, 7/plant; very high yield 1,612 g/plant; globose, dense foliage; flowers at canopy, semi-erect fruiting trusses.

Sweet Ann. Dayneutral strawberry adapted to coastal southern and central California. Origin: Lassen Canyon Nursery, Redding, CA, by J.H. Bagdasarian. 4A28 × 10B131, crossed 2005; selected in Irvine, CA, 2007; tested as 16F29; USPP 22,472, 31 Jan. 2012. Fruit: glossy red (Pantone 185C); large, $33 \mathrm{~g}$; moderately uniform conic, some wedge; moderately firm, red (1788C) flesh, balanced flavor (10.5-13.2 ${ }^{\circ}$ Brix); mid-sized reflexed surface calyx; surface achenes; early season. Plant: vigorous, few stolons; high yield, 2,617 crates/A; large globose, open; flowers at canopy, fruiting trusses; tolerant to local disease.

Winterstar $^{\mathrm{TM}}$. See FL 05-107.

Zarina. Dayneutral strawberry adapted to coastal central California. Origin: Sweet Darling Sales, Inc., Aptos, CA, by J. Larse. $1007 \times$ 880; selected in Watsonville, CA; tested as 105218; USPP 23,936, 1 Oct. 2013. Fruit: red (RHS 45A); large, $25.6 \mathrm{~g}$; variable, conic, long-conic, long-wedge; firm, orange-red (RHS 41B) and white (RHS 155C) flesh, balanced flavor; small, spreading to reflexed surface calyx; inset achenes; early season. Plant: moderate vigor, few, 2 daughter plants; very low yield, 87.5 g/plant; globose, upright, sparse foliage; flowers at canopy, prostrate fruiting trusses.

\section{INDEX}

914 CITRUS

950 CITRUS

A-1710 GRAPE

A-1960 BLACKBERRY

A-2312 BLACKBERRY

Airlie Red Flesh APPLE

Amoore Sweet NECTARINE

APF-153 BLACKBERRY

APF-77 BLACKBERRY

Arandell GRAPE

Aromella GRAPE

Artemisz APPLE

ASFNBF0688 NECTARINE

ASFNBF0796 PEACH

ASFNBF0798 PEACH
Aspen White PEACH

Aurora BLUE HONEYSUCKLE

Australian Finger Lime CITRUS

Autumn Fantasy INTERSPECIFIC PLUM

Avana apireno CITRUS

Avana tardivo di Ciacalli CITRUS

B3F44 APPLE

B3F45 APPLE

Bahianinha CITRUS

Bahianinha Araras CITRUS

Barak STRAWBERRY

Bella Jewel PUBESCENT PRUNOPHORA HYBRID

Bella Kat INTERSPECIFIC PLUM

Bella Zee INTERSPECIFIC PLUM

Ben Chaska CURRANT

Ben Como CURRANT

Benicia STRAWBERRY

Betty-cot PUBESCENT PRUNOPHORA HYBRID

Black Magic $^{\text {TM }}$ BLACKBERRY

Black Majesty IV INTERSPECIFIC PLUM

Blackred IX INTERSPECIFIC PLUM

Blackred VI INTERSPECIFIC PLUM

Blaze POMEGRANATE

Blue Ribbon BLUEBERRY

Blue Silk BLUEBERRY

Blueberry Glaze BLUEBERRY

Bob STRAWBERRY

Bobolink $^{\mathrm{TM}}$ BLUEBERRY

Bouquetier de Nice CITRUS

Bowden NECTARINE

Burpeachtwentyeight PEACH

Burpeachtwentyfive PEACH

Burpeachtwentyseven PEACH

Burpeachtwentysix PEACH

Burpeachtwentythree PEACH

C4-15-19 CITRUS

C51-63 GRAPE

Caifornia Roja CITRUS

Cakelove NECTARINE

Cakepearl NECTARINE

Cakeredal NECTARINE

Candy Cane PEACH

Capri STRAWBERRY

Cargo BLUEBERRY

Cascade Harvest RED RASPBERRY

CH 101 APPLE

Chikadee $^{\text {TM }}$ BLUEBERRY

China S-9 CITRUS

Cipria BLUEBERRY

Clockwork BLUEBRRY

Clutha Summer APRICOT

CN 121 APPLE

CN B60 APPLE

Columbia Star BLACKBERRY

Controller $^{\circledR} 6$ PEACH ROOTSTOCK

Controller $^{\circledR} 7$ PEACH ROOTSTOCK

Controller $^{\circledR} 8$ PEACH ROOTSTOCK

Controller $^{\circledR}$ 9.5 PEACH ROOTSTOCK

Cordelia APPLE

Cosmopolitan BLUEBERRY

Cotton Candy $^{\text {TM }}$ GRAPE

Country cot PUBESCENT PRUNOPHORA HYBRID

Crimson Night RED RASPBERRY

Crispbella PEACH

Cupcake STRAWBERRY

Dely STRAWBERRY

Densipac PEACH ROOTSTOCK

Double Gold RED RASPBERRY

DrisBlackThree BLACKBERRY

Driscoll's ${ }^{\circledR}$ Monica $^{\text {TM }}$ BLACKBERRY

DrisStrawEighteen STRAWBERRY 
DrisStrawNineteen STRAWBERRY

DrisStrawTwenty STRAWBERRY

DrisStrawTwentyEight STRAWBERRY

DrisStrawTwentyFive STRAWBERRY

DrisStrawTwentyFour STRAWBERRY

DrisStrawTwentyOne STRAWBERRY

DrisStrawTwentySeven STRAWBERRY

DrisStrawTwentySix STRAWBERRY

DrisStrawTwentyThree STRAWBERRY

DrisStrawTwentyTwo STRAWBERRY

DS 22 APPLE

DS 3 APPLE

Early St. Ann CITRUS

Ebony Rose INTERSPECIFIC PLUM

Eboshi Ao BLUEBERRY

FairchildLS CITRUS

Faith GRAPE

Festival Red INTERSPECIFIC PLUM

Fire Time NECTARINE

FL 05-107 STRAWBERRY

FL03-291 BLUEBERRY

FL04-235 BLUEBERRY

FL05-107 BLUEBERRY

FL05-627 BLUEBERRY

Flair STRAWBERRY

Flatbeauti PEACH

Flatbella PEACH

Flavor Blast INTERSPECIFIC PLUM

Flavorfest STRAWBERRY

Fujion APPLE

Fuku-berry BLUEBERRY

Fukushu CITRUS

Gemini APPLE

Georgia Dawn $^{\text {TM }}$ BLUEBERRY

Ginza STRAWBERRY

Glacier Princess PEACH

Glacier Queen PEACH

Glory Red PLUM

Golden Globe POMEGRANATE

Golden Parsi APPLE

Gradirose APPLE

Gradiyel APPLE

Gratitude GRAPE

Green Globe POMEGRANATE

Greensweet XX INTERSPECIFIC PLUM

Greensweet XXI INTERSPECIFIC PLUM

Hansen CITRUS

HBOK 10 PEACH ROOTSTOCK

HBOK 27 PEACH ROOTSTOCK

HBOK 32 PEACH ROOTSTOCK

HBOK 50 PEACH ROOTSTOCK

Heaven Can Wait ${ }^{\text {TM }}$ BLACKBERRY

Hesztia APPLE

Hickson CITRUS

HJ-7 BLACKBERRY

Hope GRAPE

IFG Eight GRAPE

IFG Five GRAPE

IFG Nine GRAPE

IFG Seven GRAPE

IFG Six GRAPE

Imperial CITRUS

Independence ALMOND

Inored APPLE

Ivory May PEACH

Jack's Salute ${ }^{\text {TM }}$ GRAPE

Jam Session BLEBERRY

Jelly Bean BLUEBERRY

Jin Yu PEACH

Jinva Ao BLUEBERRY

Joly STRAWBERRY
Joy GRAPE

June Time PEACH

KinnowLS CITRUS

Kodiak PEACH

Kylese PUBESCENT PRUNOPHORA HYBRID

Last Call BLUEBERRY

Latesweet XX INTERSPECIFIC PLUM

Latesweet XXI INTERSPECIFIC PLUM

Lemonade CITRUS

Lielogu BLUEBERRY

Macy-cot PUBESCENT PRUNOPHORA HYBRID

Malwina STRAWBERRY

Marge ELDERBERRY

Marumi CITRUS

Merit STRAWBERRY

Miyamoto CITRUS

Mojave STRAWBERRY

Monalisa APPLE

Nabila STRAWBERRY

NC1 APPLE

Nectardream NECTARINE

Nectarlove NECTARINE

Nectarperf NECTARINE

Nectarruby NECTARINE

Nectartic NECTARINE

Newell-Kimzey APPLE

Ningzhi 1 BLACKBERRY

Ningzhi 2 BLACKBERRY

Niwot BLACK RASPBERRY

NJ354 PEACH

NJ355 PEACH

NJ356 PEACH

Nocturne BLUEBERRY

NR7 RED RASPBERRY

Ocean Blue BLUEBERRY

OLL - 8 CITRUS

Osage BLACKBERRY

Overtime BLUEBERRY

Peach Sorbet BLUEBERRY

Pearl Time NECTARINE

Pearlicious I NECTARINE

Pearlicious II NECTARINE

Pearlicious VI NECTARINE

Pearlicious VII NECTARINE

Perpetua BLUEBERRY

Phoenicia POMEGRANATE

Picnic APPLE

Pink Icing BLUEBERRY

Planasa 02-32 STRAWBERRY

Plumac APPLE

Plumcandy X INTERSPECIFIC PLUM

Plumred IX INTERSPECIFIC PLUM

Plumred VII INTERSPECIFIC PLUM

Plumred VIII INTERSPECIFIC PLUM

Plumsweet XIV INTERSPECIFIC PLUM

Plumsweet XV INTERSPECIFIC PLUM

Polar Princess PEACH

PremA17 APPLE

PremA193 APPLE

Premier Star APPLE

Prime-Ark ${ }^{\circledR}$ Freedom BLACKBERRY

Primosole CITRUS

Rania STRAWBERRY

Raspberry ShortCake ${ }^{\mathrm{T} M}$ RASPBERRY

Raven $^{\text {TM }}$ BLUEBERRY

Red Candy LIGONBERRY

Reuben BLACKBERRY

Rocio BLUEBERRY

Romero BLUEBERRY

$\operatorname{Rootpac}^{\circledR} 20$ PEACH ROOTSTOCK

Rosamia POMEGRANATE 
Rosmerta APPLE

Rubidoux \#1 CITRUS

Rubidoux \#2 CITRUS

Sabrina STRAWBERRY

Salaspils Izturīgā BLUEBERRY

Santa Teresa CITRUS

Sauzee Lady PEACH

Sitka PEACH

Smerelda APPLE

Solano PERSIAN WALNUT

Southfield APPLE

Souvenirs PEACH

SPB-7 CITRUS

Spring Fire PEACH

Stella BLACKBERRY

Sudachi CITRUS

Sundance CRANBERRY

Sunki CITRUS ROOTSTOCK

Supareil ALMOND

Supechseventeen PEACH

Suplumfortyfour PLUM

Sweet Ann STRAWBERRY

Sweet Enchantment ${ }^{\mathrm{TM}}$ GRAPE

Sweet Jubilee ${ }^{\text {TM }}$ GRAPE

Sweet Pixzee 2 INTERSPECIFIC PLUM

Sweet Sapphire $^{\text {TM }}$ GRAPE

Sweetcrisp BLUEBERRY

Sweetheart ALMOND

Sweetregal PEACH

Sweetreine PEACH

T-959 BLUEBERRY

TH-819 BLUEBERRY

Tickled Pink $^{\text {TM }}$ GRAPE

$\operatorname{Titan}^{\text {TM }}$ BLUEBERRY

Top Shelf BLUEBERRY

UF 914 CITRUS

UF 950 CITRUS

UFSharp PEACH

US Furr CITRUS

US Furr-ST CITRUS

Utsugi Ao BLUEBERRY

Valley Pearl GRAPE

Ventura BLUEBERRY

Verna CITRUS

VI 570 CITRUS

VI 571 CITRUS

VI 621 CITRUS

VI 636 CITRUS

VI 673 CITRUS

VI 684 CITRUS

VI 685 CITRUS

VI 687 CITRUS

VI 688 CITRUS
VI 693 CITRUS

VI 697 CITRUS

VI 699 CITRUS

VI 700 CITRUS

VI 701 CITRUS

VI 709 CITRUS

VI 720 CITRUS

VI 734 CITRUS

VI 760 CITRUS

VI 777 CITRUS

VI 779 CITRUS

VI 805 CITRUS

VI 825 CITRUS

VI 835 CITRUS

Vireo $^{\text {TM }}$ BLUEBERRY

WA38 APPLE

White Diamond PEACH

WI-92-A-X15 CRANBERRY

Winterstar $^{\mathrm{TM}}$ STRAWBERRY

Xie Shan CITRUS

Zarina STRAWBERRY

Zee Pride PEACH

ZF05-196 BLUEBERRY

ZF06-043 BLUEBERRY

ZF06-079 BLUEBERRY

ZF06-179 BLUEBRRY

ZF06-288 BLUEBERRY

ZF08-095 BLUEBERRY

\section{ADDENDA}

BLACKBERRY

APF-45. USPP 22,249; 10 Jan. 2012 (List 45)

HJ-6. USPP 23,270; 25 Dec. 2012 (List 46)

PERSIAN WALNUT ROOTSTOCK

RX1. USPP 20,649; 19 Jan. 2010 (List 45).

VX211. USPP 21,179; 3 Aug. 2010 (List 45).

PEACH ROOTSTOCKS

MP-29. USPP 23,583 issued 7 May, 2013. (List 46).

RASPBERRY

Explorer black raspberry: self-infertile; requires pollinator (List 44)

Crimson Giant red raspberry: USPP 23,375 5 Feb, 2013. (List 46)

STRAWBERRY

NY99-15 (Purple Wonder ${ }^{\text {TM}}$ ), 'Walker' (List 46).

Puget Crimson. PP22,781, 12 June 2012 (List 46).

Viva Patricia. PP22,717, 8 May 2012 (List 45). 